UNIVERSIDADE DE SÃO PAULO

FACULDADE DE FILOSOFIA, CIÊNCIAS E LETRAS DE RIBEIRÃO PRETO PROGRAMA DE PÓS-GRADUAÇÃO EM EDUCAÇÃO

\title{
ARGUMENTAÇÃO, LIVRO DIDÁTICO E DISCURSO JORNALÍSTICO: VOZES QUE SE CRUZAM NA DISPUTA PELO DIZER E SILENCIAR
}

NOEMI LEMES

RIBEIRÃO PRETO - SP 
NOEMI LEMES

\title{
ARGUMENTAÇÃO, LIVRO DIDÁTICO E DISCURSO JORNALÍSTICO: VOZES QUE SE CRUZAM NA DISPUTA PELO DIZER E SILENCIAR
}

\author{
Dissertação de Mestrado apresentada ao \\ programa de pós-graduação em Educação da \\ Faculdade de Filosofia, Ciências e Letras de \\ Ribeirão Preto como requisito parcial para a \\ obtenção do título de Mestre em Educação. \\ Orientadora: $\operatorname{Prof}^{\mathrm{a}} \operatorname{Dr}^{\mathrm{a}}$ Soraya Maria \\ Romano Pacífico
}

RIBEIRÃO PRETO - SP 
Autorizo a reprodução e divulgação total ou parcial deste trabalho, por qualquer meio convencional ou eletrônico, para fins de estudo e pesquisa, desde que citada a fonte.

Lemes, Noemi

Argumentação, Livro Didático e Discurso Jornalístico: vozes que se cruzam na disputa pelo dizer e silenciar. Ribeirão Preto, 2013.

116 p. : ; $30 \mathrm{~cm}$

Dissertação de Mestrado, apresentada à Faculdade de Filosofia, Ciências e Letras de Ribeirão Preto/USP. Área de concentração: Educação.

Orientador: Pacífico, Soraya Maria Romano

1. Discurso. Argumentação. Livro Didático. Discurso Jornalístico. 
Nome: Lemes, Noemi

Título: Argumentação, Livro didático e Discurso Jornalístico: vozes que se cruzam na disputa pelo dizer e silenciar

Dissertação de Mestrado apresentada ao Programa de PósGraduação em Educação da Faculdade de Filosofia, Ciências e Letras de Ribeirão Preto da Universidade de São Paulo como requisito parcial para a obtenção do título de Mestre em Educação

Aprovado em

Banca Examinadora

Prof. Dr.

Instituição: Assinatura:

Prof. Dr.

Instituição: Assinatura:

Prof. Dr. Instituição: Assinatura: 
Aos meus amados pais, Darcy e Creusa, por instaurarem sentidos de amor, no perdão 


\section{AGRADECIMENTOS}

A doce amiga e orientadora Prof ${ }^{\mathrm{a}} \operatorname{Dr}^{\mathrm{a}}$ Soraya Maria Romano Pacífico, por ter, com afeto, “afetado” meus discursos, por criar condições para que eu ocupasse o lugar de autora e por ser protagonista neste momento tão especial da minha vida.

Ao recém-nascido Programa de Pós-Graduação em Educação, pela honra de pertencer à primeira turma.

A Coordenação de Aperfeiçoamento de Pessoal de Nível Superior, por financiar esta pesquisa.

Aos meus amigos, pelas tão diferentes interlocuções.

Aos meus irmãos, Wagner, Darcy e André, pelo amor.

Ao Zé, pela capa, por tudo... 


\section{RESUMO}

Este trabalho buscou analisar, ancorado na Análise de Discurso de filiação francesa, a qual tem em Michel Pêcheux seu autor de referência, quais as posições discursivas ocupadas por sujeitosalunos do último ano do Ensino Médio quando lhes é solicitada a produção de um texto dissertativo-argumentativo. Isso porque, na perspectiva discursiva o ato de argumentar constitui-se como uma posição discursiva que o sujeito pode ou não ocupar. Investigamos, assim, quais as implicações, para esses sujeitos-alunos, do modo como a argumentação é tratada, no livro didático, uma vez que a circulação do discurso jornalístico é usada como modelo de texto argumentativo a ser seguido por esses estudantes. Para isso, partimos de um corpus constituído por quatro livros didáticos de língua portuguesa utilizados, no Ensino Médio, nos dias atuais, em escolas públicas da cidade de Ribeirão Preto, no interior de São Paulo e, também, por textos dissertativo-argumentativos produzidos por sujeitos-alunos do terceiro ano do Ensino Médio que frequentam essas escolas. Analisamos, primeiramente, as seções dos livros didáticos de língua portuguesa destinadas ao ensino do texto argumentativo e verificamos que, dos quatro livros analisados, apenas um dedica um pequeno espaço para tratar do conceito de silogismo fazendo, inclusive, menção a Aristóteles; nos demais, a teoria sobre argumentação não se faz presente e, em seu lugar, o que encontramos foram apontamentos sobre as características de textos jornalísticos apresentados como exemplos de textos argumentativos. Após a análise dos livros didáticos, voltamos nosso olhar para os textos dissertativo-argumentativos produzidos pelos sujeitos-alunos com base em uma proposta contida em um dos livros didáticos analisados e que também trazia como matéria prima para a produção escrita, o discurso jornalístico. Fundamentadas nos pressupostos teóricos da Análise de Discurso, criamos uma espécie de escuta discursiva e buscamos, nas marcas linguísticas desses textos, quais eram os efeitos de sentido produzidos pelos sujeitos-alunos. Constatamos, então, que a esses sujeitos não está sendo permitido ocupar o lugar autoral de quem argumenta e defende seu ponto de vista; pelo contrário, a ausência de uma teoria da argumentação e a imposição do discurso jornalístico pelo livro didático possibilita apenas a reprodução das opiniões e dos sentidos trazidos pela mídia.

Palavras-chave: Discurso; Argumentação; Livro Didático; Discurso Jornalístico. 


\section{ABSTRACT}

This work analyses, anchored in Discourse Analysis of French parentage, which has in Pêcheux its author of reference, which discursive positions are occupied by subjects-students of the last year of high school when they are asked to produce an argumentative-dissertative text. We consider, through the discursive perspective, that the act of argue is seen as a discursive position that the subject may or may not occupy. We investigated, thus, the implications for these subjects-students of the way how the argumentation is treated in the textbook, once the circulation of the journalistic discourse is used as a model of argumentative text to be followed by the students. For this, we start from a corpus composed by four textbooks of portuguese language used in high school, currently, in public schools in the city of Ribeirão Preto, São Paulo, and also argumentative-dissertative texts produced by subject-students of the third year of high school who attend these public schools. Firstly, we analysed the sections of textbooks dedicated to the argumentative text teaching and found that, of the four books analysed, only one devotes a little space to discuss the concept of syllogism, mentioning Aristotle, in the others, the theory of argumentation is not present and, in its place, we could only found some characteristics of journalistic texts presented as examples of argumentative texts. After analysing the textbooks, a particular attention was paid to the dissertative-argumentative texts produced by the subjects-students based on a proposal contained in one of the textbooks analysed, which also brings the journalistic discourse as raw material for the students to produce their texts. Based on the theoretical principles of Discourse Analysis, we created a kind of discursive listen, searching, in the linguistic marks of these texts, what were the meaning effects produced by the subjects in their texts. We observed that for these subjects are not being allowed to take the authorial place of who argues and defends their points of view, but, on the contrary, the absence of a theory of argumentation and the imposition of journalistic discourse by textbook provides just the reproduction of the opinions and the meanings brought by the media.

Keywords: Discourse, Argumentation; Textbook; Journalistic Discourse. 
Eu tenho ideias e razões, conheço a cor dos argumentos e nunca chego aos corações.

Fernando Pessoa 


\section{Sumário}

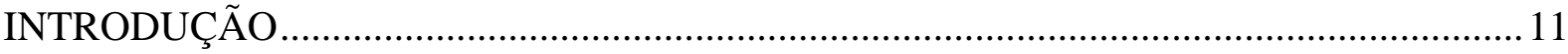

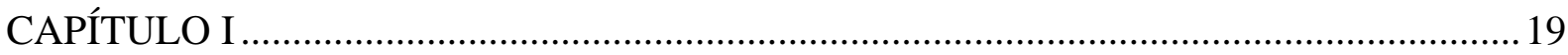

Os discursos em suas condições de produção: dispositivos metodológicos e corpus de nossa

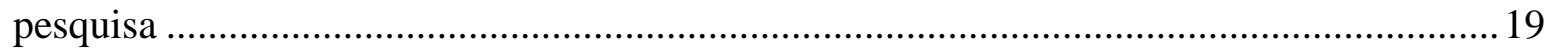

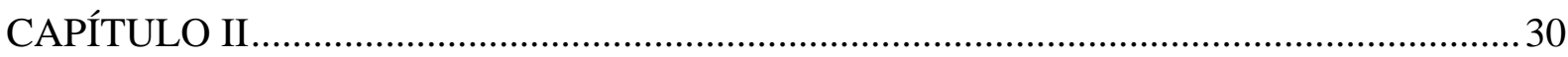

A Análise de Discurso: a lente que amplia nosso olhar ...................................................30

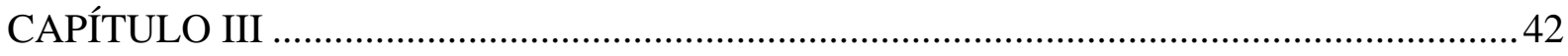

A(s) retórica(s) pela Análise de Discurso: um percurso da argumentação e sua interdição na

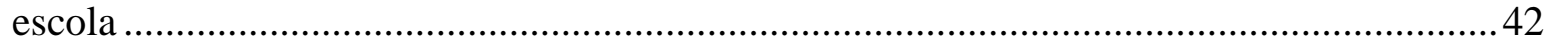

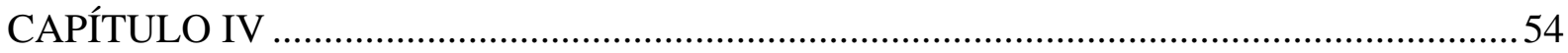

A argumentação e o discurso jornalístico no livro didático: um cruzamento de vozes........54

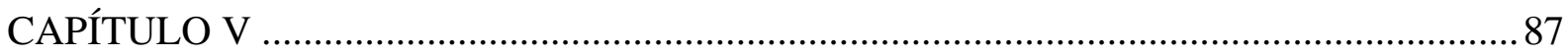

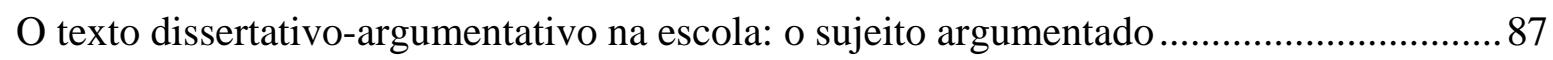

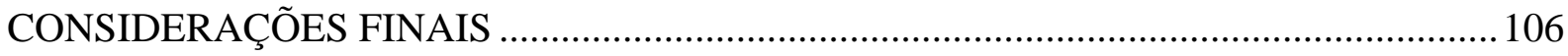

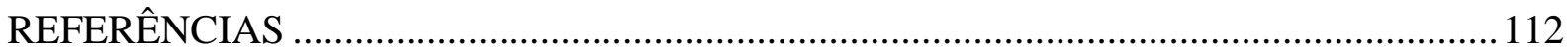

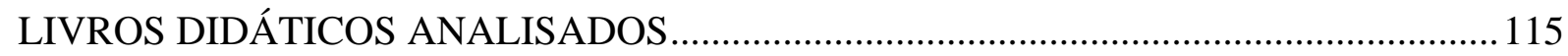




\section{INTRODUÇÃO}

Lugar onde se faz o que já foi feito, branco da página, soma de todos os textos, foi-se o tempo quando, escrevendo, era preciso uma folha isenta. Nenhuma página jamais foi limpa. Mesmo a mais Saara, ártica, significa. Nunca houve isso, uma página em branco. No fundo, todas gritam, pálidas de tanto.

(Paulo Leminski - Plena Pausa)

Durante o trajeto escolar de grande parte das crianças e dos jovens, eles são colocados em contato com o livro didático, cujo funcionamento faz com que os sentidos presentes nesse material sejam quase sempre repetidos e não questionados pelos sujeitos-escolares. Isso porque o livro didático, de acordo com Grigoletto (1999), funciona como um “discurso de verdade”, sustentado pelo seu modo de funcionamento, sobre o qual discorre a autora (1999, p.68):

\footnotetext{
O modo de funcionamento do livro didático como um discurso de verdade pode ser reconhecido em vários aspectos: no seu caráter homogeneizante, que é dado pelo efeito de uniformização provocado nos alunos (i.e., todos são levados a fazer a mesma leitura, a chegar às mesmas conclusões, a reagir de uma única forma às propostas do manual); na repetição de uma estrutura comum a todas as unidades, com tipos de seções e de exercícios que se mantêm constantes por todo o livro, fator que contribui para o efeito de uniformização nas reações dos educandos; e na apresentação das formas e dos conteúdos como naturais, criando-se o efeito de um discurso cuja verdade "já está lá”, na sua concepção.
}

Esse fato pode ser agravado quando tal material encontra no professor uma voz que o legitima, ou seja, quando o docente não questiona tais sentidos e, ao contrário disso, exige de seus alunos somente a cópia, a paráfrase. 
Tal situação pôde ser constatada ao longo de nossa vivência escolar, seja no contato com professores, na docência e até mesmo em nossa experiência como estudante. Talvez por esse motivo tenhamos nos sentido tão intrigadas com os discursos presentes no livro didático e também com os efeitos provocados pela legitimação desse material, o que nos levou a pensar mais seriamente sobre a questão.

Entendemos que no contexto de sala de aula, o uso desse material didático adquire diferentes significados e funções dependendo do tratamento que o professor lhe confere. Por outro lado, nossa experiência nos permite concordar com Grigoletto quando ela pontua que “o livro didático é concebido como um espaço fechado de sentidos, e é dessa forma que ele se impõe, e é normalmente acatado, pelo professor” (GRIGOLETTO, 1999, p.68). E, até porque trabalhamos numa perspectiva discursiva, não podemos deixar de marcar que, enquanto portador de texto que veicula a ideologia da classe dominante (PACÍFICO, 2008), esse material funciona, na escola, como uma voz de verdade, ou seja, parte-se do pressuposto de que tudo que nele está escrito seja verdadeiro e deva, portanto, ser respeitado e corroborado.

Movidas, então, por essa questão, demos início em 2009 a uma pesquisa ${ }^{1}$ que buscou investigar de que maneira o livro didático levava o conhecimento científico para a sala de aula, uma vez que esse último é altamente valorizado em nossa sociedade e tido como um dos bens comuns mais importantes. Constatamos que o livro didático legitima o discurso de divulgação científica, ou jornalismo científico, em detrimento do discurso científico. Nessa ocasião, nosso olhar se voltou para o discurso jornalístico sobre a ciência, buscando analisar os efeitos de sentido produzidos a partir desse discurso e como o conhecimento científico chegava aos sujeitos-alunos a partir dele.

Para isso, abordamos a questão sob a perspectiva discursiva, ancorando nossos estudos na Análise de Discurso de matriz francesa, a qual não considera apenas a linguagem em si, mas leva também em conta a exterioridade como parte constitutiva de todo discurso, ou seja, considera a história e as condições de produção como agentes que afetam diretamente os discursos. Por isso, de acordo com Orlandi (2007b, p.21), "as relações de linguagem são relações de sujeitos e de sentidos e seus efeitos são múltiplos e variados”, daí definir o discurso como “efeito de sentido entre locutores” (PÊCHEUX, 1995).

Foi assim, olhando para as condições sócio-histórico-ideológicas envolvidas na produção discursiva, que pudemos observar que os sentidos produzidos no/pelo discurso do

\footnotetext{
${ }^{1}$ Essa pesquisa foi realizada na forma de iniciação científica e contou com a concessão da bolsa RUSP no período de Outubro de 2009 a Outubro de 2010.
} 
jornalismo científico não equivalem aos sentidos encontrados no discurso científico, o que, por sua vez, fez com que olhássemos com estranhamento para o fato de que o livro didático vinha dando espaço e, muitas vezes, privilegiando o discurso do jornalista em detrimento do discurso da ciência.

Antes de chegarmos a essas conclusões, voltamos nosso olhar, primeiramente, para livros didáticos de ciências, nos quais encontramos uma infinidade de textos jornalísticos tratando de temas científicos e buscamos, posteriormente, os textos científicos que deram origem a eles. Dessa maneira, conseguimos analisar os deslizamentos de sentido que ocorriam no "transporte" de um para outro e o quanto esse "transporte” se configurava como perda, na medida em que os sentidos de cientificidade eram "silenciados” (ORLANDI, 2007a) para darem lugar a outros sentidos, rarefeitos de ciência. Cabe, aqui, destacar o conceito de silêncio proposto por Orlandi (2007a, p.105):

O silêncio não é ausência de palavras. Impor o silêncio não é calar o interlocutor mas impedi-lo de sustentar outro discurso. Em condições dadas, fala-se para não dizer (ou não permitir que se digam) coisas que podem causar rupturas significativas na relação de sentidos. As palavras vêm carregadas de silêncio(s).

Diante desse conceito, entendemos que, no caso que analisávamos, eram as palavras dos textos jornalísticos, presentes nos livros didáticos, que vinham carregadas de silêncio, pois, dando voz a esse discurso, os sentidos sobre ciência eram, necessariamente, calados ou, nos termos de Orlandi (2007a, p.22), “silenciados”.

Após essa verificação, buscamos nos livros didáticos de língua portuguesa discursos jornalísticos que nos apontassem para esse mesmo movimento dos sentidos, mas o que encontramos foi diferente e fez com que atentássemos para outras funções dos textos jornalísticos. Percebemos, assim, que, enquanto nos livros didáticos das ciências exatas o objetivo desse discurso é praticamente o mesmo que se encontra na revista, ou seja, "difundir” o conhecimento científico por meio da voz do jornalista, nos de língua portuguesa, esses textos servem, normalmente, de modelo ou de pretexto para o ensino de leis e regras gramaticais, por exemplo. No entanto, essa não foi a única função do discurso jornalístico que pôde ser observada, pois, em muitos momentos, o livro de língua portuguesa também apresentava os textos jornalísticos como aqueles que proporcionariam ao aluno os conhecimentos necessários para compreender diversos temas e utilizava-os, inclusive, como modelos para que, a partir deles, os alunos pudessem desenvolver suas produções textuais. Porém, assim como Pfeiffer 
(2004, p.22), entendemos que “o modelo, quando é apenas modelo, é esvaziado de sentido, estanca-se na repetição empírica ou formal”.

Dessa maneira, vimos o discurso midiático ${ }^{2}$ ser utilizado na escola de modo a se fazer valer como o próprio conhecimento teórico sobre a argumentação ${ }^{3}$ e, embora não fosse esse o foco da pesquisa que ora realizávamos, sentimo-nos preocupadas e desejosas de uma investigação mais apurada sobre a questão, uma vez que consideramos ilegítimo, para os alunos, o "silenciamento" (ORLANDI, 2007a) de uma teoria sobre o escrever, sobre o argumentar.

Consideramos que a argumentação é um conhecimento imprescindível na vida de todo e qualquer sujeito, sendo útil não apenas no caso do aprendizado da língua materna, mas também nos vários outros campos de saberes e na vida cotidiana de um modo geral. Podemos ainda confirmar essa importância da argumentação quando pensamos discursivamente sobre ela, assim, entendemos que "o ato de argumentar, isto é, de orientar o discurso no sentido de determinadas conclusões, constitui o ato linguístico fundamental, pois a todo e qualquer discurso subjaz uma ideologia” (KOCH, 2011, p.17). Dessa forma, tratando-se a argumentação de um saber muito amplo e longe de querermos reduzí-lo, cumpre frisar que, no caso dessa pesquisa de mestrado, restringímo-nos a olhar para a argumentação aplicada na escrita, ou seja, no seu ensino voltado especificamente para a construção do texto dissertativo-argumentativo.

Mesmo assim, não desprezamos a amplidão das teorias sobre o argumentar, pelo contrário, entendemos que desde os primeiros estudos sobre a retórica, ou seja, sobre a "faculdade de observar, em cada caso, o que este encerra de próprio para criar a persuasão" (ARISTÓTELES, 2011, p.44), a argumentação tem se firmado enquanto um saber extremamente relevante, dotado de particularidades e útil para a vida em sociedade. Por isso, defendemos seu ensino como um direito dos sujeitos-alunos e vemos como muito pertinente um trabalho que trate especificamente do ensino da argumentação na escola, pois sendo este um conhecimento que é, muitas vezes, visto como demasiadamente complexo, seu ensino fica, quase sempre, delegado aos últimos anos escolares. Esse adiamento parece estar sustentado por um discurso que promove a ideia de que apenas após o “total” domínio da língua o sujeito

\footnotetext{
${ }^{2}$ Embora seja essa a denominação presente no título de nossa pesquisa, vale frisar que tratamos de um discurso midiático específico, a saber, o discurso presente em textos jornalísticos retirados de jornais e revistas e que circulam nos livros didáticos.

3 Entendida, aqui, como o conjunto de saberes que permite, no desenvolvimento de um texto dissertativoargumentativo, por exemplo, o uso de recursos que induzem à aceitação de uma tese e ou de um determinado ponto de vista.
} 
estaria apto a trabalhar com a escrita de maneira argumentativa, o que, na verdade, pode configurar-se como uma subestimação da capacidade dos alunos de lidarem com um saber mais elaborado e, neste caso, o acesso ao saber argumentar como um direito dos alunos estaria comprometido.

Sabemos também que muitas são as relações de poder que perpassam o ensino da língua, principalmente no caso da escrita. Isso porque, mesmo em uma realidade em que o acesso à escola tenha sido ampliado, podemos dizer que a língua padrão ainda é um "sistema comunicativo ao alcance de uma parte reduzida dos integrantes de uma comunidade; é um sistema associado a um patrimônio cultural apresentado como um 'corpus' definido de valores, fixados na tradição escrita” (GNERRE, 1998, p.6). Entendemos, também, que escrever não se restringe a argumentar, pois o texto argumentativo é apenas um gênero textual e também está relacionado ao modo como os interlocutores usam a escrita. Portanto, estudar escrita é tomar para si um objeto muito complexo e frente a essa complexidade selecionamos, nesta pesquisa, o texto dissertativo-argumentativo como nosso objeto de investigação.

Além disso, entendemos que é papel da escola, quando se trata do trabalho com a produção textual - principalmente no caso da produção argumentativa -, oferecer vários textos e gêneros discursivos sobre os diversos temas aos alunos e promover o debate, a "disputa pelo objeto discursivo” (PACÍFICO, 2002, p.49).

Assim, considerando não apenas as ciências dos números e das fórmulas, mas levando em conta o campo das ciências humanas, como o da língua portuguesa, vemos que também neste caso faz-se necessária a circulação de teorias nas quais os sujeitos-alunos possam fundamentar a prática de sua escrita. Tais teorias podem/devem, inclusive, levar em conta os muitos estudos que vêm sendo realizados sobre a questão da linguagem.

Vale ressaltar que compreendemos a escola como um espaço no qual circulam vários discursos dos mais diferentes gêneros e, ao nos posicionar a favor da circulação de teorias sobre o argumentar, estamos defendendo que circule também o discurso científico sobre a argumentação, inclusive pelo do livro didático. Não se trata, portanto, de condenar a presença do discurso jornalístico, por exemplo, até porque, entendemos que todos os gêneros devem fazer parte do âmbito escolar. O que criticamos é a presença exaustiva de determinado gênero, no material didático, e o silêncio de tantos outros. Por outro lado, sendo a escola considerada o lugar privilegiado da/para a circulação da ciência (GARCIA, 2008), não podemos esperar que apenas a leitura de um texto jornalístico seja suficiente para que o sujeito-aluno argumente.

Pacífico (2002), em sua tese de doutorado, analisou redações produzidas por universitários e chegou à conclusão de que eles não assumem a autoria de seus textos, tampouco 
exercem o poder de argumentação. Para a autora (idem), a interdição à argumentação está relacionada a uma prática pedagógica pautada na paráfrase, na repetição de sentidos, de modelos, o que não coloca o sujeito-aluno em contato com o discurso polêmico (ORLANDI, 2003), necessário para que a argumentação se instale; logo, o lugar de quem pode argumentar não é ocupado pelos alunos dos Ensinos Fundamental e Médio. Sobre essa dificuldade em assumir a autoria e argumentar Pacífico (2002, p. 167) considera que:

[...] criar o efeito-autor no texto argumentativo deve ser mais complicado do que nos textos narrativos e descritivos, porque, no texto argumentativo, a "deformação" do real envolve uma "multiplicidade" (usando o termo de Calvino, 1990) de conhecimentos, entendendo multiplicidade como uma rede de conexões entre os fatos, entre as pessoas, entre as coisas e o mundo. E do que temos visto, podemos afirmar que o sujeito não tem acesso a esta "multiplicidade" de conhecimentos, não tem acesso ao arquivo, conforme discutimos, pois o conhecimento sobre o referente chega ao sujeito (aluno) pela visão que o professor tem do objeto.

Seria essa a realidade encontrada, ainda hoje, nas escolas? Qual a implicação dos livros didáticos de língua portuguesa nessa situação? De que modo a ausência de uma teoria sobre argumentação, nos livros didáticos, e o uso de textos jornalísticos como modelo afetariam as produções textuais de alunos do Ensino Médio em relação à possibilidade, ou não, de eles ocuparem um lugar destinado àqueles que podem argumentar? São justamente essas as questões que impulsionam a investigação a que damos início neste trabalho de mestrado.

De modo, então, a respondermos essas questões, desenvolvemos essa pesquisa de mestrado, textualizada nessa dissertação e que, já na presente introdução, traz apontados os aspectos gerais da pesquisa e seus objetivos gerais. Destacamos de início quais foram os motivos que nos impulsionaram à investigação desse tema, discorrendo, para isso, sobre a pesquisa de iniciação científica que realizamos anteriormente e a partir da qual vários questionamentos foram surgindo. Pontuamos, também, nesta introdução, algumas considerações sobre o ensino da argumentação que, para nós, justificam a relevância dos estudos a esse respeito e, por isso, influenciaram diretamente a escolha desse nosso tema.

Seguido da introdução, encontramos o primeiro capítulo de nossa dissertação, no qual, tratando da composição de nosso corpus, contextualizamos o momento da coleta dos livros didáticos e caracterizamos brevemente as coleções a que pertencem esses livros, servindo-nos para isso do Guia de livros didáticos do Programa Nacional do Livro Didático do ano de 2012. Ainda no capítulo primeiro, temos consideradas as condições de produção nas quais se deram as produções textuais dos alunos, bem como os dispositivos metodológicos que sustentam 
nossas análises, tanto dos recortes dos livros quanto dos textos argumentativos presentes em nosso corpus.

Continuando as reflexões e discussões iniciadas já na introdução e com o objetivo de aprofundá-las, apresentamos no segundo capítulo desse trabalho as discussões teóricas que fundamentam nossa pesquisa. Tratamos, assim, dos principais conceitos da Análise de Discurso de linha francesa que embasam nosso trabalho, apresentando tais conceitos e destacando o modo como essa perspectiva discursiva nos ajuda a olhar para o funcionamento tanto dos discursos que circulam no livro didático quanto para os discursos elaborados pelos próprios sujeitos-alunos em seus textos argumentativos.

Pensando ainda na fundamentação de nossa pesquisa, consideramos pertinente desenvolvermos um capítulo terceiro que apresentasse a argumentação como um saber que se encontra situado dentro de determinado campo teórico. Para isso, selecionamos, dentre os vários estudos desse campo do saber, um dos primeiros textos sobre a argumentação, qual seja, a obra aristotélica intitulada "Retórica”, da qual partimos para pensarmos quais teorias sobre o argumentar poderiam circular na escola, inclusive por meio do livro didático, e quais mecanismos poderiam subsidiar a argumentatividade dos textos nas produções escritas dos alunos. Tendo, assim, levantado os principais conceitos trazidos por Aristóteles sobre a arte da persuasão, partimos da Análise de Discurso para lançarmos um olhar para tais conceitos, estabelecendo relações entre as duas teorias e, assim, pensando na argumentação como uma posição que pode ou não ser ocupada pelos sujeitos-alunos.

Tendo, então, discutido os dispositivos metodológicos que nos auxiliam em nossas análises e feito um estudo sobre os fundamentos teóricos da pesquisa, iniciamos, no quarto capítulo desse trabalho, nossas análises propriamente ditas. No capítulo quatro, em que se propõe a análise de recortes retirados dos livros didáticos, incluindo os textos jornalísticos apresentados nele, o leitor terá a oportunidade de entrar em contato com os discursos e sentidos presentes nesses recortes e poderá também acompanhar como fomos analisando, por meio de marcas linguísticas presentes nessa materialidade textual, os efeitos de sentido trazidos pelo discurso midiático - mais propriamente pelo discurso jornalístico-, no livro didático. Destacamos, aqui, também o modo como os livros didáticos propõem o trabalho com o texto jornalístico, apresentando as atividades de leitura e compreensão de texto que acompanham os discursos midiáticos e buscando, também nelas, marcas que nos forneçam indícios sobre qual é o tratamento dado a esses discursos e quais efeitos de sentido podem ser gerados a partir disso.

Logo em seguida, apresentamos, no quinto capítulo do nosso trabalho, a análise de uma proposta de redação trazida por um livro didático de língua portuguesa, bem como análises de 
alguns textos dissertativo-argumentativos produzidos por sujeitos-alunos com base nela. Nesse caso, por meio da análise dessas produções textuais, poderemos observar como os alunos constroem sentidos sobre determinado tema a partir de uma proposta de trabalho do livro didático em que textos jornalísticos são utilizados como modelo e, principalmente, se eles ocupam o lugar destinado à argumentação. Analisaremos se os sentidos trazidos pelos textos midiáticos são questionados e contra argumentados pelos estudantes ou se existe apenas reiteração do sentido apresentado pela mídia jornalística. Assim, o que buscamos foi pensar no âmbito do discurso, ou seja, na materialidade histórica da língua, cuja verificação nos possibilita analisar o modo de funcionamento pelo qual um texto produz sentidos, nesse caso, o modo específico de funcionamento do discurso jornalístico e, mais tarde, os sentidos produzidos pelos sujeitos-alunos em seus textos, cuja proposta de escrita era o texto dissertativo-argumentativo.

Por fim, apresentamos as considerações finais sobre a pesquisa e sobre o evento que aqui nos propomos investigar. Assim, depois de fundamentar nossa pesquisa e de “concluirmos” nossas análises, discorreremos sobre o que foi possível observar, ou seja, se vem sendo apresentada ou não alguma teoria da argumentação por meio do livro didático e os efeitos disso nos textos dissertativo-argumentativos produzidos pelos sujeitos-alunos.

Sabemos que os sentidos sobre o tema que escolhemos investigar não se esgotarão aqui, nas páginas dessa dissertação de mestrado. Por outro lado, argumentamos que a compreensão do nosso principal objeto de pesquisa, ou seja, o cruzamento entre as vozes da argumentação, do discurso midiático e do livro didático, que se sustenta num jogo de poder dizer e silenciar, passe também pelos sentidos que aqui atribuímos. 


\section{CAPÍTULO I}

\section{Os discursos em suas condições de produção: dispositivos metodológicos e corpus de nossa pesquisa}

Oco de pau que diz: eu sou madeira, beira Boa, dá vau, triztriz, risca certeira Meio a meio o rio ri, silencioso, sério Nosso pai não diz, diz: risca terceira Água da palavra, água calada, pura Água da palavra, água de rosa dura Proa da palavra, duro silêncio, nosso pai, Margem da palavra entre as escuras duas Margens da palavra, clareira, luz madura Rosa da palavra, puro silêncio, nosso pai Meio a meio o rio ri por entre as árvores da vida

O rio riu, ri por sob a risca da canoa

O rio viu, vi. E ninguém jamais ouviu

Ouvi, ouvi, ouvi a voz das águas

Asa da palavra, asa parada agora Casa da palavra, onde o silêncio mora Brasa da palavra, a hora clara, nosso pai Hora da palavra, quando não se diz nada Fora da palavra, quando mais dentro aflora Tora da palavra, rio, pau enorme, nosso pai

(A terceira margem do rio - Milton Nascimento)

Como sugerido no título deste trabalho, pretendemos analisar como circulam, na escola, as vozes que produzem sentidos sobre argumentação. Desse modo, buscamos compreender o movimento dessas vozes, a saber: as teorias sobre argumentação, o livro didático, a voz do jornalista e a voz do sujeito-aluno. Para nós, o movimento dessas vozes se dá na forma de um cruzamento, ou seja, o encontro delas representaria também um momento de sobreposição de uma voz em relação à outra, uma disputa na qual, para que uma voz tenha espaço, outra tenha que ser “calada”. Em nosso caso, temos visto, desde a pesquisa de iniciação científica, a voz do discurso jornalístico ganhando lugar de destaque no do livro didático enquanto a voz do discurso científico - aquela que traz as teorias e os saberes de referência - é silenciada (ORLANDI, 2007a).

Nessa disputa de vozes, deve-se levar em conta ainda que o próprio livro didático, 
material em que esses diversos discursos circulam, apresenta-se como uma voz de poder que, sendo considerada a detentora da verdade e da completude dos saberes, faz com que os sujeitos não duvidem de que o que ali circula seja o suficiente para dominarem os diversos conhecimentos. Por esse motivo, preocupa-nos a insistente circulação do discurso jornalístico nos livros didáticos, uma vez que, sendo este utilizado para o ensino da argumentação, pode-se criar nos sujeitos-alunos a ilusão de não haver nenhum saber teórico que pudesse subsidiar o aprendizado da "arte de argumentar” (PACÍFICO, 2002, p.44), mas que, ao contrário, tudo que se tem sobre argumentação esteja ali, na matéria jornalística trazida pelo livro, inclusive com as opiniões e os sentidos admitidos como “corretos” sobre os vários temas.

Para investigarmos, então, os modos de funcionamento desses discursos e como isso afeta a produção textual dos sujeitos-alunos, construímos a seguinte metodologia. Fomos até escolas públicas de Ensino Médio da cidade de Ribeirão Preto, no interior do estado de São Paulo, em busca dos livros didáticos de língua portuguesa que estão sendo utilizados, atualmente, bem como de textos dissertativo-argumentativos produzidos por alunos, do terceiro ano do Ensino Médio dessas escolas, a partir das propostas encontradas nesses livros didáticos. Frisamos que a opção por analisarmos apenas os livros utilizados no terceiro ano do Ensino Médio e as redações produzidas por alunos dessa etapa escolar deu-se por considerarmos esse um período marcado pela proximidade dos exames vestibulares, nos quais, pelo menos em nosso estado, predomina a exigência do texto do gênero dissertativo-argumentativo.

Dentro desse contexto, poderíamos pensar em uma possível intensificação no estudo da argumentação e, também, em um sentimento de expectativa, por parte dos alunos, com a chegada dessas provas vestibulares. Isso, somado a tantos outros fatores, ajudaria a compor as condições nas quais o aprendizado desse conteúdo estaria ocorrendo e, também por essa razão, interessou-nos pesquisar o ensino da argumentação dentro de tais condições.

Do mesmo modo, como para o analista de discurso é crucial considerar as condições em que os discursos são produzidos, entendemos que o momento da coleta dos dados também compõe as condições em que essa nossa pesquisa foi realizada e, por isso, consideramos extremamente pertinente relatar aqui, ainda que sucintamente, como se deu o momento em que nosso corpus foi constituído.

Assim, começamos dizendo que a escolha das escolas nas quais buscamos tanto os livros didáticos quanto as produções textuais dos alunos deu-se de maneira aleatória. Percorremos dez escolas públicas de Ribeirão Preto em que havia Ensino Médio; porém, apenas quatro mostraram-se abertas a colaborarem com a pesquisa. Dessas quatro, somente duas permitiram que, além dos livros didáticos, recolhêssemos também textos argumentativos produzidos por 
seus alunos. Cabe lembrar que, em todas as visitas às escolas, nosso corpus só era coletado mediante a apresentação documental da pesquisa e consentimento da direção e coordenação das escolas.

Em nossas visitas, procurávamos sempre estabelecer um contato amistoso para com aqueles que nos atendiam, frisando sempre que era totalmente opcional a participação ou não na pesquisa e que, em nenhum momento, o nome da escola ou de qualquer aluno seria citado em nosso trabalho. Mesmo assim, na maior parte das escolas visitadas, encontrávamos certa resistência, antes mesmo que explicássemos de que se tratava a pesquisa. Tal resistência era manifestada, por vezes, em uma recusa pronta e categórica, normalmente após mencionarmos que estávamos ligadas à Universidade de São Paulo; outras vezes, pediam para que voltássemos em outros momentos, porém, mesmo após diversas tentativas, em quatro das escolas visitadas, não conseguimos falar com nenhum responsável.

Em contrapartida, deparamo-nos com situações nas quais, além de nos receber atenciosamente, os diretores, coordenadores e professores mostravam-se interessados na pesquisa, pedindo, inclusive, para que apresentássemos nossos resultados, principalmente quanto à análise dos livros didáticos adotados pela escola.

Foi, pois, nessas condições, que coletamos nosso corpus, constituído por quatro livros didáticos de língua portuguesa de diferentes coleções, quais sejam, os terceiros volumes das seguintes coleções: “Linguagem em movimento” (TORRALVO; MINCHILLO, 2010); “Ser protagonista: português” (BARRETO, 2010); “Português - literatura, gramática, produção de texto" (SARMENTO; TUFANO, 2010) e o livro "Português linguagens” (CEREJA; MAGALHÃES, 2003). Vale destacar que, mesmo limitando-nos a analisar os livros utilizados no terceiro ano do Ensino Médio, procuramos olhar também para os primeiros e segundos volumes das respectivas coleções, de modo a compreendermos como e onde o ensino da argumentação poderia estar sendo apresentado aos alunos. No entanto, como veremos adiante, foi possível encontrar esse conteúdo apenas nos terceiros volumes das coleções observadas, utilizados no último ano do Ensino Médio. Tal evento pode estar associado a uma maior preocupação com o vestibular nesse período.

De volta à caracterização de nosso corpus, ressaltamos que todos os livros didáticos acima citados foram aprovados pelo Ministério da Educação e suas avaliações encontram-se no Guia de livros didáticos do Programa Nacional do Livro Didático (PNLD), publicado em 2011, para orientar a escolha dos livros que seriam usados no ano de 2012.

Desse modo, consideramos que a própria aprovação desses livros e a adoção deles pelas escolas colaboram com o processo de legitimação desse material e interferem nos sentidos que 
poderão ser produzidos acerca desses livros dentro da sala de aula. Julgamos importante apresentar, aqui, alguns dos principais pontos levantados, sobre eles, nas avaliações presentes no Guia de livros didáticos (BRASIL, 2011), destacando principalmente o modo como são avaliadas as seções destinadas ao ensino da produção do texto dissertativo-argumentativo, nosso foco nessa pesquisa.

Começando, então, com a coleção “Linguagem em movimento”, temos nela, de acordo com o Guia, um material que oscila entre “a tradição e a inovação” (BRASIL, 2011, p.32) e que apresenta, como um de seus pontos fracos, a forte preocupação com o exame vestibular. Por outro lado, o ensino da produção de texto, nesse material, merece destaque, segundo o Guia (BRASIL, 2011, p.35), principalmente por detalhar os gêneros discursivos para os alunos antes que o exercício da escrita seja cobrado. Com relação ao estudo do texto dissertativoargumentativo, só vemos mencionado o fato de o mesmo encontrar-se apenas no terceiro volume da coleção.

Já na coleção intitulada “Ser protagonista: português” vemos, conforme o Guia, um ensino da produção textual que, embora seja o menos extenso nas obras da coleção, preocupase em situar “a prática da escrita em seu universo de uso social” (BRASIL, 2011, p.65). Para isso, as atividades de produção de texto configuram-se da seguinte maneira de acordo com o Guia (BRASIL, 2011, p.65):

Geralmente, a unidade apresenta um texto no gênero textual a ser produzido, explora suas características e, em seguida, oferece questionamentos de compreensão da leitura. Por fim, a seção "Produzir um [gênero a ser escrito]" solicita a escrita do gênero estudado.

A respeito da produção do texto dissertativo-argumentativo, nada é comentado, mas, depois de olharmos para os demais volumes da coleção, sabemos que também nesse conjunto de livros o ensino desse gênero discursivo fica delegado ao último livro da coleção.

Passando para a coleção “Português - literatura, gramática, produção de texto”, o Guia também aponta como um dos pontos positivos da obra o fato de ela "dar oportunidade ao aluno de refletir sobre o uso da língua e compreender a função social desse uso” (BRASIL, 2011, p.47). O modo como a literatura é trabalhada também ganha evidência, pois, segundo o Guia, o livro se esforça para abordar este conteúdo “de uma forma menos cristalizada” (BRASIL, 2011, p.48). Quanto à produção de texto, nenhuma avaliação é feita sobre o ensino do texto dissertativo-argumentativo, especificamente; porém, falando de uma maneira geral de todos os gêneros trabalhados na coleção, o documento afirma que, nesse ensino, predomina a discussão 
dos aspectos formais e funcionais de cada gênero, no qual são apresentadas, inclusive, “recomendações sobre estratégias textualizadoras e adequação da linguagem aos contextos sugeridos” (BRASIL, 2011, p.50).

Chegando ao último livro que constitui nosso corpus, a saber, "Português linguagens", o Guia destaca o trabalho com a leitura, afirmando que, na obra, as atividades de leitura privilegiam “a construção de sentidos, o diálogo entre múltiplas linguagens e o desenvolvimento de diferentes estratégias cognitivas” (BRASIL, 2011, p.52). Com relação ao modo como o livro trabalha a produção de texto escrito, o Guia (BRASIL, 2011, p.55) traz os seguintes comentários:

O eixo da produção de texto, centrado na perspectiva dos gêneros textuais, é
articulado ao eixo da leitura e traz orientações para, por exemplo, a produção
de notícia e reportagem, resumo, seminário, e-mail e blog, poema, texto teatral,
fábula e apólogo, crônica literária. Em toda a obra, o eixo da produção segue
essa organização - que envolve a leitura e a análise de exemplares dos gêneros
- com maior ou menor detalhamento de seus aspectos formais e discursivos e
com orientações precisas sobre o contexto e as etapas de produção. São
apresentados, com clareza, elementos que servem de subsídios temáticos e
orientações sobre o registro adequado de linguagem e outros aspectos
específicos da textualidade.

Embora aqui, também, não haja nenhuma menção ao texto argumentativo, vemos que, de um modo geral, o ensino da produção de texto é baseado em um esquema que contempla a leitura e o uso de modelos para que os alunos compreendam as características típicas dos vários gêneros textuais.

Cabe enfatizar que nosso propósito com essas breves caracterizações das coleções a que pertencem os livros didáticos não é o de analisarmos os discursos presentes no Guia do PNLD sobre esses livros, mas apenas contextualizarmos nosso corpus, levando em conta, assim, que os recortes que vamos analisar circulam dentro de um material que, como vimos, apresenta modos de funcionamento específicos. Além disso, entendemos que o livro didático é uma ferramenta que tem sua própria história e, nesse sentido, não nos caberia pensar em um livro ideal, até porque, nosso foco nesta pesquisa de mestrado não é o livro didático em si, mas a voz de autoridade que o mesmo representa e também os discursos que ele faz circular na escola.

Assim, em nossas análises, não trabalharemos com os livros na íntegra, mas com a noção de recorte, que, para a Análise de Discurso, segundo Orlandi (2003, p.160), é entendida como “uma unidade discursiva: fragmento correlacionado de linguagem - e situação”. A Análise de Discurso ultrapassa a noção de informação, do mensurável e trabalha com a noção de texto, 
tendo o recorte uma relação com a constituição histórica do sentido do texto. Portanto, a Análise de Discurso propõe a passagem do segmento para o recorte, e da frase para o texto.

Ainda para Orlandi (2003, p.160), “o texto é o todo que organiza os recortes. Esse todo tem compromisso com as tais condições de produção, com a situação discursiva. (...) A ideia de recorte remete à noção de polissemia e não de informação”. Dessa forma, os recortes, aqui, não devem ser compreendidos enquanto estrutura linear, mas sim, como pedaços, “nacos” do discurso, onde estarão materializados linguisticamente os indícios de um modo de funcionamento.

No caso dos recortes retirados dos livros didáticos, buscamos analisar, além de nacos das seções que tratam do ensino da argumentação, alguns textos jornalísticos acompanhados de atividades de "interpretação" e as sequentes propostas de produção textual de caráter dissertativo-argumentativo. Tal análise foi feita a fim de observarmos como as teorias sobre argumentação são (ou não) contempladas no livro didático e também como o discurso jornalístico é trabalhado nesse material, particularmente quando ele é usado como exemplo de texto argumentativo.

Somando-se a isso, nosso corpus também é formado por textos produzidos por alunos do $3^{\circ}$ ano do Ensino Médio a partir de uma proposta de redação encontrada em um dos livros didáticos analisados. Nesse caso, a análise buscou investigar qual posição discursiva esses sujeitos-alunos assumem quando lhes é solicitada a produção de textos dissertativoargumentativos, ou seja, se eles exercem, ou não, o poder de argumentação e se, consequentemente, assumem sua autoria.

Também nesse caso, julgamos necessário expor as condições em que se deram a produção desses textos dissertativo-argumentativos, por isso, mesmo não estando presentes no momento da atividade de produção textual, procuramos pela docente responsável pela disciplina para que ela nos relatasse de que maneira e em que condições os alunos realizaram a tarefa de escrever o texto. Assim, segundo a professora de língua portuguesa da turma, as aulas dedicadas ao ensino da produção textual se baseiam, na maioria das vezes, nas propostas contidas no livro didático, por isso, esse momento de escrita, cujo produto materializou-se nas produções textuais de nosso corpus, constituiu um exercício comum no cotidiano dos alunos desse terceiro ano do Ensino Médio e sua realização deu-se em após a leitura do texto, com o momento da produção de texto, em sala de aula. Após termos visitado a escola e solicitado a colaboração da docente para a obtenção dos textos, tivemos que aguardar duas semanas para que pudéssemos voltar à escola e coletar as produções dos alunos. De acordo com a professora, esse seria o tempo necessário para que ela, não deixando de lado sua programação com os 
conteúdos, pudesse realizar a proposta de redação com os alunos.

Ainda conforme a docente, o dia em que foram feitas as produções argumentativas configurou-se como um dia normal de aula de produção de texto, realizada dentro de duas aulas de cinquenta minutos cada. Desse modo, a proposta foi lida pela professora, juntamente com os alunos, ela abriu um pequeno espaço para que eles expusessem oralmente suas opiniões sobre o tema e, logo em seguida, conforme a proposta do livro, foi solicitada a composição de um texto dissertativo-argumentativo.

Aqui também não intentamos avaliar ou julgar se as condições foram ou não as ideais. Entendemos, inclusive, que existem muitos outros fatores que podem estar envolvidos tanto no modo como se processou o ensino da argumentação para essa turma como nas próprias condições de produção dos textos argumentativos dos alunos. Porém, como analistas de discurso, faz-se imprescindível levarmos em consideração as circunstâncias em que os discursos são produzidos e, mais que isso, o contexto sócio-histórico ideológico que é aquele que "traz para a consideração dos efeitos de sentido elementos que derivam da forma de nossa sociedade, com suas instituições” (ORLANDI, 2007b, p.31), dentre elas a escola, com sua história, suas relações de poder, com suas ferramentas de ensino, como, por exemplo, o livro didático e tudo que ele pode representar. Todos esses elementos nos ajudam a pensar sobre nosso corpus e contribuem com nossas análises.

Vale destacar ainda que, a partir da Análise de Discurso, consideramos a própria seleção do corpus como parte do trabalho de análise e, por isso, concordamos com Orlandi (2007b, p.64) quando ela afirma que:

\footnotetext{
A análise é um processo que começa pelo próprio estabelecimento do corpus e que se organiza face à natureza do material e à pergunta (ponto de vista) que o organiza. Daí a necessidade de que a teoria intervenha a todo momento para "reger" a relação do analista com seu objeto, com os sentidos, com ele mesmo, com a interpretação.
}

Temos, dessa maneira, outra perspectiva através da qual podemos olhar para a questão da interpretação e que diz respeito ao próprio trabalho da Análise de Discurso. Nesse sentido, não caberia ao analista e, portanto, não nos cabe, em nossas análises, a busca por um sentido do texto que estaria escondido nas palavras. Ao contrário disso, o trabalho do analista se pauta no funcionamento da linguagem, em sua materialidade específica e, consequentemente, não consiste em interpretar, mas em colocar em questão a interpretação. Por isso, concordamos com Pêcheux (apud ORLANDI, 1996, p.64) quando ele afirma que "interpretar, para o analista de discurso, não é atribuir sentido, mas expor-se à opacidade do texto”, do que resulta saber que o 
“sentido sempre pode ser outro”. Vista dessa maneira, a interpretação não se fecha, pois os sentidos não existem em si mesmos, eles estão sempre em movimento, deslocando-se para significarem diversamente.

Além disso, pensar o trabalho da Análise de Discurso faz com que voltemos nosso olhar para a matéria a partir da qual o analista desenvolve suas análises, a saber, o texto. É importante destacar que o texto, sendo uma “unidade fundamental da linguagem” (ORLANDI, 2001, p.159), configura-se como uma materialidade do discurso na qual as palavras ganham significação, pois temos nele a "textualização da memória”. No entanto, segundo Orlandi (2007b, p.72):

\begin{abstract}
Um texto é só uma peça de linguagem de um processo discursivo bem mais abrangente e é assim que deve ser considerado. Ele é um exemplar do discurso. Feita a análise, não é sobre o texto que falará o analista mas sobre o discurso. Uma vez atingido o processo discursivo que é responsável pelo modo como o texto significa, o texto ou textos particulares analisados desaparecem como referências específicas para dar lugar à compreensão de todo um processo discursivo do qual eles - e outros que nem conhecemos - são parte.
\end{abstract}

Nesse sentido, para a Análise de Discurso de linha francesa, não existe discurso originado e finalizado em si mesmo, por isso, não buscamos, em nossos dispositivos metodológicos, trabalhar a partir de uma perspectiva quantitativa, mesmo porque, como nos diz Orlandi (2007b, p. 62) a respeito do trabalho do analista:

\footnotetext{
Não se objetiva, nessa forma de análise, a exaustividade que chamamos horizontal, ou seja, em extensão, nem a completude, ou exaustividade em relação ao objeto empírico. Ele é inesgotável. Isso porque, por definição, todo discurso se estabelece na relação com um discurso anterior e aponta para outro. Não há discurso fechado em si mesmo mas um processo discursivo do qual se podem recortar e analisar estados diferentes.
}

Em razão do que precede, podemos dizer que nosso trabalho não buscou testar nenhuma teoria a partir de uma quantidade exaustiva de textos analisados, nem mesmo intentou extrair desses discursos todos os seus sentidos possíveis para, então, atribuir aos mesmos um único sentido como verdadeiro. Ao contrário disso, trabalhamos com a “opacidade” desses discursos (ORLANDI, 1996), com a historicidade dos mesmos que foi apagada em seu processo de produção, mas que pode ser recuperada com base nos pressupostos teóricos aos quais o analista recorre, o qual não despreza os indícios, o diferente, o equívoco que sempre pode vir a ser. De acordo com Ferreira (2008, p. 16) temos que: 
Quanto à historicidade, vamos considerá-la como a inscrição da história na língua e o movimento dos sentidos no texto, que atuam no sujeito como âncora e como bússola, sustentando e orientando seu trabalho de interpretação. Essa presença da exterioridade, como o sentido lá, é o que torna possível a relação do sujeito com a própria língua, relação essa afetada pelas determinações histórico-sociais que se marcam na materialidade do discurso.

Desse modo, sabemos que o texto é uma das formas nas quais o discurso materializa-se e é nessa materialidade que está também inscrita a relação desses discursos com a exterioridade.

Para que o analista do discurso possa realizar sua análise é necessário que ele também ocupe diversos lugares, investigando o dado, não como um fato acessível e observável, mas sim, como a possibilidade do vir a ser, do sentido que está para ser construído.

Consideramos muito relevante essa postura no que se refere aos estudos linguísticos, uma vez que cada ato de linguagem é novo e único e, portanto, deve ser analisado considerando suas condições de produção para, então, analisar o modo de funcionamento do discurso, por que o sentido caminha para uma direção e não para outra. Isso significa que a Análise de Discurso se preocupa com o processo de construção do discurso e não com o seu produto.

Nesse sentido, faremos uso de um importante instrumento para analisarmos a construção dos discursos, qual seja, o “paradigma indiciário” de Ginzburg (2002). Tal paradigma tem suas raízes traçadas a partir dos trabalhos do italiano Giovanni Morelli, que desenvolveu um minucioso método de análise, a partir do qual era possível atribuir obras de arte antigas aos seus verdadeiros autores, bem como distinguir se um quadro, por exemplo, era original ou não. Assim, a partir de detalhes presentes nas pinturas como, por exemplo, os lóbulos das orelhas, o formato das unhas ou as formas dos dedos, era possível identificar o autor da obra.

De acordo com Ginzburg (2002, p. 149-150), o “método morelliano” chama a atenção por tratar-se da:

[...] proposta de um método interpretativo centrado sobre os resíduos, sobre os dados marginais, considerados reveladores. Desse modo, pormenores normalmente considerados sem importância, ou até triviais, "baixos", forneciam a chave para aceder aos produtos mais elevados do espírito humano.

São, pois, essas características do método que vão, inclusive, influenciar a obra psicanalítica de Freud, uma vez que, tendo entrado em contato com os textos de Morelli, Freud menciona o método do italiano em seu ensaio “O Moisés de Michelangelo”, dizendo que tal método está estreitamente ligado à técnica da psicanálise médica, pois em ambos busca-se “penetrar em coisas concretas e ocultas através de elementos pouco notados ou desapercebidos” (Freud apud GINZBURG, 2002, p. 147). 
Além disso, a intensidade na busca pelas minudências e pelas pistas também fizeram o método de Morelli ser associado ao modo como o famoso detetive Sherlock Holmes, personagem criado por Arthur Conan Doyle, conduzia suas investigações. Para a personagem, assim como para Morelli, nenhum detalhe, por menor que fosse, poderia ser desprezado no momento das análises, o que, no caso de Holmes, garantiria o sucesso na resolução dos enigmas.

Por outro lado, falando do paradigma indiciário de uma maneira mais estrita, Ginzburg afirma que, "uma coisa é analisar pegadas, astros, fezes (animais ou humanas), catarros, córneas, pulsações, campos de neve ou cinzas de cigarro; outra é analisar escritas, pinturas ou discursos” (GINZBURG, 2002, p.171). Nesse sentido, diferentemente das técnicas utilizadas pela personagem de Conan Doyle, que analisava, em grande parte, matérias pertencente à natureza, o paradigma indiciário ocupa-se de um sistema de signos determinados culturalmente, como é o caso das palavras, por exemplo. Assim, o que interessa são os indícios involuntários, ou seja, aquilo que, muitas vezes, sem intenção, aparece, rompe no discurso (oral ou escrito) do sujeito.

É, portanto, a partir do método morelliano que surge o paradigma indiciário, tendo sido, este último, afirmado nas ciências humanas, dentre elas também na linguística, fornecendo, dessa maneira, múltiplas possibilidades para a análise, inclusive, de textos escritos. Segundo Ginzburg (2002, p.177), “se a realidade é opaca, existem zonas privilegiadas - sinais, indícios - que permitem decifrá-la”. No nosso caso, esses indícios configuram-se enquanto marcas linguísticas presentes tanto nos recortes extraídos dos livros didáticos quanto nas produções textuais dos sujeitos-alunos. Ainda para o autor (idem), essas marcas se configuram como pistas, ou seja, elas não são encontradas diretamente, mas antes, exigem do analista um trabalho de teorização para, então atingi-las.

Desse modo, a partir de tal instrumento de análise, buscamos “colocar em evidência os traços dos processos discursivos” (PÊCHEUX, 1997, p.55), trabalhando primeiramente com a materialidade linguística do texto, de modo a remetê-la a funcionamentos discursivos específicos. Observamos quais são os “efeitos de sentido” (PÊCHEUX, 1995) gerados pelo discurso jornalístico, lembrando aqui que esse discurso está presente no livro didático, que, por sua vez, possui um modo de funcionamento próprio. Posteriormente, analisamos também quais são os efeitos de sentido produzidos pelos sujeitos-alunos em seus textos argumentativos quando o discurso jornalístico é apresentado como “fôrma” em que o aluno deve basear-se no momento da escrita.

Consideramos, pois, essas questões de enorme relevância na medida em que afetam diretamente os sujeitos envolvidos nesse processo e concordamos ainda que é papel daqueles 
que estão na universidade investigar essas questões, duvidando da neutralidade e da transparência da linguagem, dos sentidos; buscando compreender como o conhecimento sobre o argumentar tem chegado (ou não) na escola, instituição que tem o poder e o dever de fazer circular e de distribuir o conhecimento. 


\section{CAPÍTULO II}

\section{A Análise de Discurso: a lente que amplia nosso olhar}

Certa palavra dorme na sombra de um livro raro. Como desencantá-la? É a senha da vida a senha do mundo. Vou procurá-la.

Vou procurá-la a vida inteira no mundo todo. Se tarda o encontro, se não a encontro, não desanimo, procuro sempre. Procuro sempre, e minha procura ficará sendo minha palavra.

(Carlos Drummond de Andrade - A Palavra Mágica)

Como já apontado desde a introdução desse trabalho, nosso olhar tanto para o livro didático quanto para os textos dissertativo-argumentativos se dá na perspectiva discursiva, ou seja, procuramos analisar o modo de funcionamento do livro didático no que diz respeito ao ensino da argumentação e, depois, investigamos quais as posições que os sujeitos-alunos permitem-se ocupar para produzirem seus discursos e que efeitos de sentido são criados a partir disso. Por essa razão, recorremos à Análise de Discurso de matriz francesa como teoria que irá guiar nosso olhar e consideramos extremamente importante discorrer sobre alguns pressupostos teóricos que permeiam nossa pesquisa.

Tal perspectiva teórica, focada nos trabalhos de Michel Pêcheux, pressupõe que os sujeitos e os sentidos se constituem simultaneamente, ou seja, não há existência espontânea do sujeito, assim como não há evidência do sentido. Nesse sentido, o indivíduo é interpelado em 
sujeito pela ideologia e isso, por sua vez, faz com que a evidência tanto do sujeito quanto do sentido seja um efeito ideológico no qual, ainda de acordo com Pêcheux (1995, p.152-153):

[...] o caráter comum das estruturas-funcionamentos designadas, respectivamente, como ideologia e inconsciente é o de dissimular sua própria existência no interior mesmo do seu funcionamento produzindo um tecido de evidências “subjetivas”, devendo entender-se este último adjetivo não como "que afetam o sujeito”, mas "nas quais se constitui o sujeito.

Vista dessa maneira, a ideologia não representa uma visão de mundo ou um conjunto de ideias imposto à sociedade em um determinado contexto histórico e que afeta os sujeitos. Ela, ao contrário, exerce o papel de “mecanismo de naturalização dos sentidos” (PACÍFICO, 2002), que simula, através da ilusão de transparência da linguagem, a existência de um sentido único e pronto, contido nas palavras, como se elas significassem tudo, sempre da mesma maneira e para todos. Mas como, então, o sentido daquilo que dizemos, ouvimos, lemos e escrevemos nos parece tão evidente?

Para esclarecermos a questão é preciso entender que, para a Análise de Discurso pecheuxtiana, a ideologia é materializada no discurso. Pêcheux (1995, p.153), com base em Althusser, afirma que “não há discurso sem sujeito assim como não há sujeito sem ideologia”. Disso decorre que o sujeito que investigamos, aqui, não se trata de um sujeito empírico, mas de uma posição projetada no discurso. Consideramos, assim, o sujeito do discurso (sujeito de seu discurso) e temos por definição de discurso algo que não se restringe a um breve momento de fala, nem à mera transmissão de informação, mas, antes, abrangendo a noção de sentido e de ideologia, o discurso é definido como "efeito de sentido entre locutores” (PÊCHEUX, 1995), o que, por sua vez, vai de encontro à ideia de que o sujeito, estando na origem de seu dizer, possui o domínio dos sentidos presentes naquilo que diz. Ao contrário dessa ideia, ainda, segundo Pêcheux (1995), tais efeitos de sentido, longe de representarem a intencionalidade dos sujeitos, são construídos de acordo com as condições sócio-histórico-ideológicas e afetam os interlocutores do discurso.

Continuando com Pêcheux (1995), essa ilusão de completude dos sentidos, de que aquilo que dizemos só pode significar de uma maneira, mascara o que o autor denomina “o caráter material do sentido”, ou seja, apaga-se que a constituição dos sentidos apresenta uma relação intrínseca com o “todo complexo das formações ideológicas” e que, por isso, os sentidos mudam de acordo com as posições sustentadas pelos sujeitos do discurso. Vale destacar que essa tomada de posição do sujeito é possível mediante a sua inscrição em uma formação discursiva que corresponde, no discurso, a uma formação ideológica. Para a Análise de Discurso 
francesa, formação discursiva pode ser definida como aquilo que, a partir da posição social ocupada pelo sujeito, pode e deve ser dito em uma determinada conjuntura, ou melhor, aquilo que é permitido ao sujeito dizer dentro de uma formação ideológica específica. Deste modo, “o discurso se constitui em seu sentido porque aquilo que o sujeito diz se inscreve em uma formação discursiva e não em outra para ter um sentido e não outro” (ORLANDI, 2007b, p.43).

Do que precede, podemos inferir que as palavras não apresentam um sentido contido nelas mesmas, advindo de uma literalidade ou do que, por vezes, podemos ouvir ser chamado de "sentido literal" - como se houvesse um -; ao contrário, as palavras adquirem ou perdem seus sentidos a partir da formação discursiva na qual elas se encontram, sendo essa última, então, o lugar de constituição dos sentidos. Daí, entendermos que as mesmas palavras podem significar de maneira diferente, de acordo com as formações ideológicas nas quais o dizer dos sujeitos está inscrito e, de modo correlato, palavras diferentes podem ter o mesmo sentido no interior de uma mesma formação discursiva.

Cabe, ainda, ressaltar que as formações discursivas não se configuram como um lugar estável e fechado em que prevalece uma projeção do “modo de pensar” de um grupo social. Elas, ao contrário, são “uma realidade heterogênea por si mesma” (MAINGUENEAU, 1997, p.112), pois se constituem a partir de suas inúmeras relações e articulações, sendo, então, marcadas pela contradição e pelo entrelaçamento de vários discursos. Chegamos, assim, à ideia de que "em um texto não encontramos apenas uma formação discursiva, pois ele pode ser atravessado por várias formações discursivas que nele se organizam em função de uma dominante” (ORLANDI, 2007b, p.70).

Ainda tratando das condições de produção do discurso e, portando, dos sentidos, faz-se necessário entender também que “toda formação discursiva dissimula, pela transparência do sentido que nela se constitui, sua dependência com respeito ao "todo complexo com dominante” das formações discursivas” (PÊCHEUX, 1995, p.147), do que podemos depreender que, os discursos e sentidos construídos em determinada formação discursiva não advêm do acaso ou de si mesmos, mas são produzidos a partir de outros discursos, estão, pois, atrelados a uma série de dizeres anteriores.

A partir do que está dito, podemos familiarizar-nos com outro importante conceito da Análise de discurso, a saber, o interdiscurso, entendido aqui como tudo aquilo que já foi dito antes e em outros lugares sobre determinado assunto - o “já-lá” que determina tudo que é possível dizermos, em dado contexto. Desse modo, é o interdiscurso que possibilita que nossas palavras façam sentido, pois quando, através dele, nosso dizer é associado a toda uma filiação 
de dizeres anteriores, temos resgatada a "historicidade” de nossas palavras e elas, então, tornamse parte do “dizível”.

Sabemos, assim, que nossas palavras são atravessadas por outras palavras, ditas antes e em outros lugares, fazendo com que várias “vozes” ressoem em nossa “voz” e vários sentidos sejam retomados, enquanto outros, migrando de outras formações discursivas, sejam deslocados de modo a significarem de maneira diversa. É esse deslocamento entre diferentes formações discursivas que nos permite entender, por exemplo, como uma mesma palavra pode ter sentidos tão diferentes, pois, como aponta Authier-Revuz (2004, p.36):

Toda palavra "remete a um contexto, ou a vários, nos quais viveu sua existência socialmente subjugada". Ela "chega a seu próprio contexto, vinda de outro contexto, penetrada pelo sentido dado por outros". As palavras são “carregadas”, “ocupadas”, "habitadas”, “atravessadas” por discursos.

Tocamos, nesse ponto, no conceito de heterogeneidade, pois, a partir do que está dito acima, sabemos que um discurso só se constrói a partir de (vários) outros. Essa, aliás, é uma condição para que o discurso aconteça, sendo, portanto, a heterogeneidade, “constitutiva do discurso” (AUTHIER-REVUZ, 2004). Podemos falar também em uma forma marcada de heterogeneidade que acontece quando o locutor dá lugar ao discurso de outro em seu próprio discurso. Isso pode acontecer por meio de citações ou mesmo quando “o locutor se comporta como um tradutor: fazendo uso de suas próprias palavras, ele remete a um outro discurso como fonte do 'sentido' dos propósitos que relata” (AUTHIER-REVUZ, 2004, p.12).

Desse modo, sabemos, ainda de acordo com Authier-Revuz (2004, p.68), que “o sujeito não é uma entidade homogênea, exterior à linguagem, que lhe serviria para 'traduzir' em palavras um sentido do qual ele seria a fonte consciente”. Pelo contrário, o sujeito para a Análise de Discurso é também heterogêneo e atravessado pelo discurso do outro (BAKHTIN, 1981). É, por isso, um sujeito afetado pela polifonia, pois ao falar, atualiza as muitas outras vozes que falaram antes, em outros lugares.

Essa atualização de outras vozes é possível graças ao funcionamento da memória discursiva. Vale lembrar que, embora alguns autores aproximem esse conceito com o de interdiscurso, tomando, por diversas vezes, um pelo outro, nossos estudos nos permitiram entender que eles se relacionam, mas não podem ser confundidos como se fossem sinônimos.

Para nós, a memória, que “deve ser entendida aqui não no sentido diretamente psicologista da memória individual” (PÊCHEUX, 2007, p.50), mas como uma “memória social inscrita em práticas”, configura-se como um recorte do interdiscurso. Esse recorte acontece em 
decorrência do efeito de leitura e interpretação de determinado sujeito sobre o eixo da constituição de um discurso, ou seja, sobre o próprio lugar do interdiscurso. Seria, dessa maneira, uma espécie de leitura subjetiva do interdiscurso, mas que também carrega em si a coletividade, uma vez que o sujeito encontra-se filiado a uma ou mais formações discursivas. Nas palavras de Pêcheux (2007, p.52):

A memória discursiva seria aquilo que, face a um texto que surge como acontecimento a ler, vem restabelecer os “implícitos” (quer dizer, mais tecnicamente, os pré-construídos, elementos citados e relatados, discursostransversos, etc.) de que sua leitura necessita: a condição do legível em relação ao próprio legível.

É, também, graças à memória discursiva que se torna possível nosso dizer, no entanto, trata-se de um dizer estruturado em duas formas de “esquecimento”, pois para dizermos algo, precisamos esquecer que as palavras e os sentidos não nascem em nós mesmos, eles existem antes, são exteriores a nós e significam dentro das formações discursivas. Da mesma forma, ao “escolhermos” nossas palavras, esquecemos necessariamente que outras palavras poderiam ser ditas em lugar daquelas que colocamos em discurso. Esses dois esquecimentos, nomeados por Pêcheux (1995), respectivamente, de “esquecimento número um” e "esquecimento número dois”, são responsáveis pela “ilusão do sujeito” de que ele possui o domínio daquilo que diz, estando na origem de seu dizer e de que há uma relação direta entre aquilo que pensa e aquilo que diz, como se suas palavras só pudessem ser aquelas. Ainda a esse respeito o que diz Orlandi (1993b, p.107-108) é relevante:

Como se sabe, essa ilusão se realiza por dois esquecimentos: a) o de que o discurso não nasce no sujeito, por isso, os sentidos não se originam nele, são retomados por ele; b) o de que ao longo do seu dizer se formam famílias parafrásticas com aquilo que ele poderia dizer mas vai rejeitando para o nãodito, e que também constitui o seu dizer (enquanto "margens”). Do primeiro esquecimento se origina a ilusão do sujeito ser fonte de seu discurso ("o que eu digo tem o sentido que eu quero", onipotência do sujeito), e do segundo se origina a ilusão da realidade de seu pensamento ("o que eu disse só pode significar x", onipotência do sentido). No primeiro se inscreve a "eficácia do assujeitamento" (ou ilusão da autonomia do sujeito), no segundo, a "estabilidade referencial” (ou ilusão da transparência dos sentidos).”

Dessa maneira, esses esquecimentos não se configuram como perda, mas, pelo contrário, são constitutivos dos sentidos e dos sujeitos, uma vez que se fazem necessárias as ilusões derivadas desses esquecimentos para que haja o dizer e para que os sujeitos, ao se identificarem com aquilo que dizem, constituam-se como sujeitos de seu discurso, significando 
suas palavras e sendo significados por elas num constante jogo em que sujeitos e sentidos se deslocam e podem sempre significar de maneira diferente.

Esse modo de funcionamento da linguagem, no qual o já-dito é retomado para, então, ser re-significado, permite-nos pensar a produção do discurso dentro de um tenso jogo entre o mesmo e o diferente, ou seja, entre a paráfrase e a polissemia. Na primeira, temos a idéia de repetição, ou como melhor especifica Orlandi (2007b, p.36), “os processos parafrásticos são aqueles pelos quais em todo dizer há sempre algo que se mantém, isto é, o dizível, a memória”. Esse processo é essencial na produção do discurso, uma vez que, para a Análise de Discurso, todo discurso se apoia necessariamente em outro(s). Já, nos processos polissêmicos, a partir da "falha" e do "equívoco", que constituem, respectivamente, a ideologia e a língua, temos a possibilidade de deslocamento e, portanto, de "ruptura de processos de significação" (ORLANDI, 2007b, p.37), de quebra com o mesmo para o surgimento do diferente. Podemos notar, dessa maneira, que os sujeitos e os sentidos não se encontram estacionados, imóveis, mas, pelo contrário, eles estão sempre se movimentando.

Compreender, dessa forma, que os sujeitos e os sentidos estão sempre em movimento no percurso do dizer - discurso - é fundamental para entendermos que a linguagem se caracteriza pela sua incompletude e que nela, nem os sujeitos e nem os sentidos estão prontos e determinados. Eles estão, na verdade, em constante processo de construção e de deslocamento, por isso é que dizemos que os sentidos podem sempre ser outros, pois concordamos com Pêcheux (1997, p.53) quando ele afirma que:

A conseqüência do que precede é que toda descrição - quer se trate da
descrição de objetos ou de acontecimentos ou de um arranjo discursivo-textual
não muda nada, a partir do momento em que nos prendemos firmemente ao
fato de que "não há metalinguagem" - está intrinsecamente exposta ao
equívoco da língua: todo enunciado é intrinsecamente suscetível de tornar-se
outro, diferente de si mesmo, se deslocar discursivamente de seu sentido para
derivar para outro.

Esse deslocamento acontece também porque a produção dos sentidos está envolvida em relações de força, ou seja, "o lugar a partir do qual fala o sujeito é constitutivo do que ele diz” (ORLANDI, 2007b, p.39) e, em uma sociedade constituída por relações hierárquicas, cada um desses lugares representa diferentes status de poder. Assim, como no próprio exemplo trazido por Orlandi (2007b, p.39), “se o sujeito fala a partir do lugar de professor, suas palavras significam de modo diferente do que se falasse do lugar do aluno”. Por isso, podemos acrescentar ainda que esses lugares de onde falam os sujeitos podem fazer com que seus dizeres 
tenham (ou não) certa autoridade, ponto importante para nós que investigamos a relação do sujeito com a argumentação.

Indo além, sabemos que esses mecanismos através dos quais funcionam os discursos baseiam-se em formações imaginárias, o que, por sua vez, faz com que ultrapassemos a noção de lugar empírico de onde fala determinado sujeito para a de posição discursiva que ele ocupa. Disso resultam imagens dos sujeitos do discurso, produzidas através de um mecanismo imaginário, cuja função Orlandi (2007b, p.40) bem descreve:

\footnotetext{
Esse mecanismo produz imagens dos sujeitos, assim como do objeto do discurso, dentro de uma conjuntura sócio-histórica. Temos assim a imagem da posição sujeito locutor (quem sou eu para lhe falar assim?) mas também da posição sujeito interlocutor (quem é ele para me falar assim, ou para que eu lhe fale assim?), e também a do objeto do discurso (do que estou lhe falando, do que ele me fala?). É pois todo um jogo imaginário que preside a troca de palavras.
}

Vemos, assim, que a produção dos sentidos passa por um complexo jogo de imagens que são projetadas no discurso. Desse modo, não é nas palavras mesmas que se encontram os sentidos, nem tampouco nas intenções de quem as profere, mas, antes, é preciso levar em conta as condições de produção de um discurso para entender o seu funcionamento e o modo como produz sentidos.

A partir do que já discutimos, podemos finalmente voltar à questão proposta no início desse capítulo, a saber, nosso questionamento sobre a evidência do sentido, e dizer que esse efeito de evidência, através do qual somos levados a acreditar que nossas palavras nos pertencem e que o sentido daquilo que dizemos só poderia ser aquele que desejamos, acontece não apenas em um discurso particular, mas é fruto de todo um "mecanismo" que rege os processos discursivos. Esse “mecanismo”, no qual os sentidos são naturalizados (Ideologia), envolve-nos através do interdiscurso, fazendo com que busquemos no já-dito o nosso dizer, ao mesmo tempo em que cria ilusões (esquecimentos) de que somos os senhores do nosso dizer. Entretanto, esse modo de funcionamento é necessário à formulação de todo discurso.

Cabe aqui dizer que não entendemos a constituição e a formulação do discurso como momentos isolados um do outro. Pelo contrário, sabemos que, quando tratamos do estudo da linguagem, principalmente, na perspectiva da Análise de Discurso francesa, entende-se a profunda ligação que a constituição dos sentidos apresenta com a sua formulação. Tanto assim que nos estudos de J. J. Courtine (apud MAINGUENEAU, 1997), ele propõe pensarmos que a formulação de todo discurso se dá na intersecção de dois eixos, apontados, a seguir, por Dominique Maingueneau (1997, p.115): 
O “vertical”, do pré-construído, do domínio de memória e o "horizontal”, da linearidade do discurso, que oculta o primeiro eixo, já que o sujeito enunciador é produzido como se interiorizasse de forma ilusória o pré-construído que sua formação discursiva impõe. O “domínio de memória” representa o interdiscurso como instância de construção de um discurso transverso que regula, tanto o modo de doação dos objetos de que fala o discurso para um sujeito enunciador, quanto o modo de articulação destes objetos.

Assim, o eixo vertical trata da constituição dos sujeitos e sentidos e o horizontal abrange a formulação do discurso em que sujeitos e sentidos aparecem. Todo discurso, então, dar-se-ia no entrecruzamento desses eixos, atestando, assim, que os mesmos não estão desvinculados e afetam igualmente a produção dos sentidos.

Tratando, porém, das especificidades do momento da formulação do discurso, Orlandi (2001, p.10) escreve que:

\begin{abstract}
Na formulação há um investimento do corpo do sujeito presente no corpo das palavras. O momento em que o sujeito diz o que diz. Em que se assume autor. Representa-se na origem do que diz com suas responsabilidades, suas necessidades. Seus sentimentos, seus desígnios, suas expectativas, sua determinação. Pois, não esqueçamos, o sujeito é determinado pela exterioridade mas, na forma-sujeito histórica que é a do capitalismo, ele se constitui por esta ambiguidade de, ao mesmo tempo, determinar o que diz. A formulação é o lugar em que esta contradição se realiza. Ela é o acontecimento discursivo pelo qual o sujeito articula manifestamente seu dizer. Dá o contorno material ao dizer instaurando o texto.
\end{abstract}

Entendida dessa maneira, a formulação do discurso se caracteriza como o momento em que sujeito e sentido tomam "corpo" nas palavras. Ela representa o momento mesmo da enunciação, quando acontece o intradiscurso - "atualização da memória discursiva” (ORLANDI, 2001) -, ou seja, "aquilo que estamos dizendo naquele momento dado, em condições dadas” (ORLANDI, 2007b). Desse modo, a formulação estabelece uma relação de dependência com a constituição do discurso, uma vez que o sujeito só pode formular seu dizer se ele se colocar no domínio do dizível (interdiscurso). Assim, todo discurso se estabelece sobre outro já estabelecido, como nos mostra Pêcheux (1995, p.167) ao afirmar que "pode-se bem dizer que o intradiscurso, enquanto 'fio do discurso' do sujeito, é, a rigor, um efeito do interdiscurso sobre si mesmo, uma "interioridade" inteiramente determinada como tal "do exterior”, e é nessa relação que os sentidos são produzidos.

Quando tratamos, então, da formulação do discurso e, portanto, do momento em que ele se materializa em um texto - apresentado tanto na forma oral quanto na escrita -, não podemos nos esquivar da concepção de que na perspectiva da Análise de Discurso não temos apenas 
transmissão de informação, na qual um emissor, fazendo uso de um código, transmite uma mensagem a um receptor. Ao contrário disso, na Análise de Discurso se faz presente a ideia de que os interlocutores não estão separados, mas realizam ao mesmo tempo o processo através do qual as palavras ganham significação. Isso porque, como já vimos, o discurso - "matéria prima” da Análise de discurso - é definido como “efeito de sentido entre locutores” (PÊCHEUX, 1995), de modo que no funcionamento da linguagem, sujeitos e sentidos são afetados pela língua e pela história para, só então, fazerem-se significar mutuamente.

É nesse complexo processo de significação, marcado pela incompletude da linguagem e pela abertura da relação pensamento/linguagem/mundo que se dá a interpretação, pois no momento em que o sujeito fala, ele já o faz interpretando, inscrevendo seu dizer em uma formação discursiva e permitindo, assim, que suas palavras façam sentido. Não há, pois, sentido sem interpretação já que a própria formulação de um discurso e, portanto, dos sentidos deriva de um gesto de interpretação. Disso decorre que a interpretação é parte constituinte da língua e que a língua, por sua vez, dá lugar à interpretação. Podemos, nesse ponto, concordar com Michel Pêcheux (1997) quando o mesmo sustenta que "todo enunciado, toda sequência de enunciados é, pois linguisticamente descritível como uma série (léxico-sintaticamente determinada) de pontos de deriva possíveis, oferecendo lugar à interpretação.” (PÊCHEUX, 1997, p.53).

Assim, esses “lugares oferecidos” à interpretação são prontamente “aceitos” pelo sujeito que, face a qualquer matéria simbólica é levado a “atribuir” sentidos, é chamado a dizer o que “aquilo” quer dizer. No entanto, as condições de produção desses sentidos se mantêm, de certa maneira, apagadas, deixando no sujeito a ilusão de que o sentido é literal, como se o sentido já estivesse nas próprias coisas e palavras. Isso acontece porque, como aponta Orlandi (2001), “é pela interpretação que o sujeito se submete à ideologia, ao efeito da literalidade, à ilusão do conteúdo, à construção da evidência dos sentidos, à impressão do sentido já-lá” (ORLANDI, 2001, p.22).

A partir dessas considerações, é possível a observação de que, embora possamos ter a ilusão de que a interpretação se configura como um gesto livre do sujeito que, frente a um texto pode atribuir-lhe os sentidos que quiser, na verdade, ele não está livre de determinações, como nos mostra Orlandi (1996, p.67-68):

A interpretação, portanto, não é mero gesto de decodificação, de apreensão do sentido. Também não é livre de determinações. Ela não pode ser qualquer uma e não é igualmente distribuída na formação social. O que a garante é a memória sob dois aspectos: a) a memória institucionalizada, ou seja, o arquivo, o trabalho social da interpretação em que se distingue quem tem e quem não tem 
direito a ela; e b) a memória constitutiva, ou seja, o interdiscurso, o trabalho histórico da constituição da interpretação (o dizível, o repetível, o saber discursivo).

Dois importantes pontos são tocados nesse dizer da autora, a saber: o primeiro refere-se à desigual distribuição da interpretação, em que uns podem interpretar enquanto a outros só é permitido repetir; o segundo refere-se à garantia da interpretação por meio da memória institucionalizada (o arquivo), cuja definição, proposta por Pêcheux (2010), vamos detalhar mais adiante. Discutiremos mais densamente essas questões, pois vemo-nas como de fundamental importância para entendermos as relações entre sujeitos e sentidos na interpretação.

Começaremos, então, a discussão pelo primeiro ponto levantado, destacando que essa desigual distribuição da interpretação se manifesta sob a ação de duas formas de controle da interpretação. A primeira é a que se dá institucionalmente, ou seja, representa uma espécie de controle historicamente determinado por permitir que, dentro das diversas formações sociais, os sujeitos e suas inúmeras relações com os sentidos sejam governados, de modo que só os sentidos permitidos possam circular, garantindo, portanto, a estabilidade discursiva. Pensar essa forma de controle nos impele a levar também em consideração a divisão social da leitura segundo a qual é dado, de acordo com Pêcheux (2010, p.52-53):

A uns, o direito de produzir leituras originais, logo "interpretações" que
constituem ao mesmo tempo atos políticos (sustentando ou enfrentando o
poder em vigor), a outros, a tarefa subalterna de preparar e de sustentar, pelos
gestos anônimos do tratamento "literal" dos documentos, as ditas
"interpretações".

Já, a segunda forma de controle advém da necessidade que o sujeito tem de controlar o “não-sentido”, de ter parte em um mundo “semanticamente estabilizado” (PÊCHEUX, 1995).

Dessas formas de controle decorre a existência de uma divisão entre aqueles que possuem o direito de interpretar e aqueles a quem isso é vetado. Da mesma maneira, há textos considerados “instáveis", nos quais os sentidos podem sempre se deslocar para outros; e textos considerados “estáveis”, em que o sentido é controlado, devendo haver apenas repetição, não dando margem a nenhuma interpretação. De acordo com Orlandi (1996, p.66), “essas divisões correspondem às formas de administração dos sentidos abundantemente praticadas nas/pelas instituições: distribuídas pelas diferentes posições dos sujeitos (pai, professor, líder sindical, patrão, líder de partido político)”. 
Podemos, agora, partir para o segundo ponto presente na citação, qual seja: o da noção de memória institucionalizada que Pêcheux (2010) denomina “arquivo”. Para o autor, o arquivo pode ser definido como "um campo de documentos pertinentes sobre uma determinada questão" e, nesse sentido, como já mencionado na citação, é o acesso a esse campo de documentos que garante a possibilidade de interpretação, pois para interpretar - e o sujeito interpreta enquanto lê, escreve e fala - ele deve assumir o que Pacífico (2002, p. 42) chama de “função-leitor”, ou seja, posição assumida pelo sujeito que "reflete sobre o verossímil, que procura compreender os sentidos prováveis, que podem ou não ser aqueles esperados, em uma determinada situação”. Do contrário, ainda de acordo com a autora, a posição discursiva que o sujeito assumirá será apenas a "fôrma-leitor”, que designa uma posição do sujeito na qual, por encontrar-se limitado pela interdição do acesso ao "arquivo”, ele apenas pode repetir um sentido que foi “cristalizado" e que é, muitas vezes, “legitimado” pelas instituições.

Para além dessas reflexões, podemos também observar que a noção de “função-leitor” apresenta uma relação direta com a questão da autoria, pois só assumirá a autoria de seu texto aquele sujeito que, frente a um texto, permite-se o confronto entre os vários sentidos possíveis, trazendo à tona, assim, a possibilidade do novo. Em outras palavras, o sujeito só será autor quando assumir a “função-leitor” (PACÍFICO, 2002).

Sob a ótica da Análise de Discurso, a noção de autor funciona como "uma função da noção de sujeito, responsável pela organização do sentido e pela unidade do texto.” (ORLANDI, 1996, p.69). Temos presente, assim, o que denominamos “função-autor” que, de acordo com Orlandi (1996), "se realiza toda vez que o produtor da linguagem se representa na origem, produzindo um texto com unidade, coerência, progressão, não contradição e fim” (ORLANDI, 1996, p.69). O sujeito, então, se faz autor quando seu texto entra no domínio do interdiscurso, ou seja, quando ele "historiciza seu dizer", produzindo um "evento interpretativo" - texto passível de interpretação -.

Dessa forma, para o sujeito assumir a posição de autor, faz-se necessário que ele seja levado a uma leitura crítica e polissêmica do texto, que ele possa também encontrar-se com outros textos, para que, então, trabalhando a partir da intertextualidade e acessando o "arquivo", ele esteja em condições de assumir sua função de autoria, inclusive argumentando sobre aquilo que lhe é apresentado. Mas de que maneira poder-se ia promover essas condições?

A tipologia discursiva proposta por Orlandi (2003) pode nos ajudar a compreender melhor a questão e pensar uma resposta para ela. De acordo com Orlandi (2003), o modo de funcionamento dos discursos pode caracterizá-los em três tipos diferentes, a saber, o lúdico, o polêmico e o autoritário. Contudo, antes de trabalharmos as especificidades de cada um deles, 
convém destacar que, segundo a autora, esses tipos de discurso, por serem construídos a partir da relação entre os interlocutores e mediante determinadas condições de produção, não estão fechados e, por isso, um discurso lúdico, por exemplo, pode “mover-se” para um autoritário ou para um polêmico durante seu próprio curso, configurando essa tipologia não como um planejamento, mas como um processo. Isso entendido, faremos uso de uma citação da própria autora para caracterizar esses tipos discursivos: (ORLANDI, 2007b, p.86):

a. discurso autoritário: aquele em que a polissemia é contida, o referente está apagado pela relação de linguagem que se estabelece e o locutor se coloca como agente exclusivo, apagando também sua relação com o interlocutor;

b. discurso polêmico: aquele em que a polissemia é controlada, o referente é disputado pelos interlocutores, e estes se mantêm em presença, numa relação tensa de disputa pelos sentidos;

c. discurso lúdico: aquele em que a polissemia está aberta, o referente está presente como tal, sendo que os interlocutores se expõem aos efeitos dessa presença inteiramente não regulando sua relação com os sentidos.

Assim, quando dizemos que, para assumir a "função-autor” e para argumentar sobre o que lê, o sujeito necessita fazer uma leitura polissêmica e mobilizar seu “arquivo”, estamos ao mesmo tempo dizendo que ele deve estar, desde cedo, em constante contato com o discurso polêmico, no qual ele pode, segundo Pacífico (2002, p. 50), “ocupar um outro lugar que não aquele ocupado por um ouvinte que recebe 'informações', mas sim, um lugar que permita ao sujeito olhar o objeto discursivo e questionar, discutir, construir os sentidos acerca disto”. Entendemos, ainda, que o papel da escola e do professor é de fundamental importância para que isso venha de fato acontecer, uma vez que o próprio argumentar é também uma posição discursiva que o sujeito pode ou não ocupar dependendo das condições que lhe são oferecidas. Nesse sentido, de acordo com Pacífico (2002), só haverá argumentação quando houver autoria, de onde depreendemos que se não há uma teoria sobre argumentação, como o sujeito-aluno poderá posicionar-se como autor?

Isso, por sua vez, leva-nos a refletir sobre a escola enquanto lugar de onde se espera a produção de um conhecimento mais detalhado sobre a argumentação e o papel do professor que, estando autorizado para tanto, deve trabalhar na construção desse conhecimento junto com seus alunos, possibilitando aos mesmos o contato com as teorias da argumentação e com os múltiplos sentidos construídos a respeito de um determinado tema para que, então, o sujeitoaluno possa formar seu ponto de vista e argumentar em favor dele. 


\section{CAPÍTULO III}

\section{A(s) retórica(s) pela Análise de Discurso: um percurso da argumentação e sua interdição na escola}

Esta língua não é minha, qualquer um percebe. Quem sabe maldigo mentiras, vai ver que só minto verdades.

Assim me falo, eu, mínima, quem sabe, eu sinto, mal sabe.

Esta não é minha língua.

A língua que eu falo trava uma canção longínqua, a voz, além, nem palavra.

$O$ dialeto que se usa à margem esquerda da frase, eis a fala que me lusa, eu, meio, eu dentro, eu, quase.

(Paulo Leminski - Invernáculo)

Defender o ensino da argumentação como conhecimento dotado de especificidades implica, primeiramente, a necessidade de contextualizarmos esse saber dentro de um determinado campo teórico, buscando as características que o definem como ciência. Nesse sentido, tratando os primeiros estudos retóricos como disciplina da antiguidade, Guiraud (apud MOSCA, 2004, p.19) ressalta que a retórica:

De todas as disciplinas antigas, é a que melhor merece o nome de ciência, pois
a amplidão das observações, a sutileza da análise, a precisão das definições, o
rigor das classificações constitui um estudo sistemático dos recursos da
linguagem, cujo equivalente não se encontra em qualquer dos outros
conhecimentos daquela época.

Assim também, considerando a argumentação uma ciência e não desprezando as muitas obras que existem hoje sobre ela, mas com o objetivo de pensarmos as origens dessa teoria, 
optamos por recorrer a um dos textos mais antigos acerca da arte de argumentar, a saber, a "Retórica"4 do filósofo grego Aristóteles.

Definida pelo filósofo como sendo a “contraparte da dialética”, a retórica é tratada, na obra aristotélica, como uma arte bastante útil na vida de todo e qualquer indivíduo, uma vez que “todos procuram discutir e sustentar teses, realizar a própria defesa e a acusação dos outros” (ARISTÓTELES, 2011, p.39). Isso, por sua vez, determina a real função desta arte que não seria, então, apenas alcançar a persuasão, mas buscar os meios para atingi-la em cada situação. Assim, entendemos por retórica, aqui, a ciência que versa sobre "o poder, diante de quase qualquer questão que nos é apresentada, de observar e descobrir o que é adequado para persuadir” (Aristóteles, 2011, p.44-45), por isso está diretamente ligada à argumentatividade de um texto, por exemplo, que é nosso foco neste trabalho.

Nesse sentido, o filósofo argumenta em favor da importância da retórica, desenvolvendo uma obra detalhada, composta por três livros, sendo o Livro I responsável por apresentar os três gêneros retóricos, dos quais derivam também três gêneros do discurso: o deliberativo, o forense e o demonstrativo. Segundo Aristóteles (2011, p.53):

O discurso deliberativo nos induz a fazer ou a não fazer algo. Um destes
procedimentos é sempre adotado por conselheiros sobre questões de interesse
particular, bem como por indivíduos que se dirigem a assembleias públicas a
respeito de questões de interesse público. O discurso forense comporta a
acusação ou a defesa de alguém; uma ou outra tem sempre que ser sustentada
pelas partes em um caso. O discurso demonstrativo ocupa-se do louvor ou da
censura de alguém.

Ainda no Livro I, temos examinadas as fontes das quais se pode extrair argumentos em cada um desses gêneros de discurso, assim como "as opiniões e as proposições que são úteis para os meios de persuasão nessas áreas” (ARISTÓTELES, 2011, p.121). Aqui, destaca-se também a importância do entimema para a retórica, que equivale ao conceito de silogismo, estudado na dialética e já desenvolvido por Aristóteles em obras anteriores. Assim, enquanto no silogismo temos uma espécie de raciocínio argumentativo composto basicamente por duas premissas e uma conclusão, no entimema acontece algo semelhante, com a diferença de que uma ou mais premissas podem ser suprimidas por serem consideradas óbvias ou já conhecidas. Tais conceitos são caros ao estudo dos meios de persuasão uma vez que, "aquilo que é

\footnotetext{
${ }^{4}$ Como, ao longo deste capítulo, tratamos de outras definições de/para retórica - vista aqui também como a arte de persuadir em si e, outras vezes, como disciplina que compunha nosso antigo currículo escolar -, optamos por marcar com aspas e inicial maiúscula toda vez que nos referirmos especificamente à conhecida obra aristotélica.
} 
persuasivo o é para alguém, e algo é persuasivo quer porque é de imediato e por si só evidente, quer porque parece ser demonstrado a partir de outras premissas que são, elas, persuasivas e convincentes” (ARISTÓTELES, 2011, p.47).

Já no Livro II, Aristóteles vai tratar das paixões (ou emoções) que, despertadas no ouvinte, podem gerar determinadas disposições do espírito para a recepção do discurso retórico. Neste segundo livro, uma série de paixões como, por exemplo, a cólera, a compaixão, o medo e também seus opostos são analisados no sentido de fornecer ao leitor as técnicas para incitar tais sentimentos em seus ouvintes e assim, obter a adesão dos mesmos. Além da questão das paixões, esse livro II também trata, de maneira mais detalhada, das formas de argumentação, ou seja, da maneira como devem ser utilizados recursos como as máximas, os entimemas, os exemplos, etc.

Chegando ao Livro III, último livro que compõe a "Retórica”, Aristóteles se dedica ao tratamento do estilo e da organização das partes do discurso. Para o autor, "a excelência do estilo consiste na clareza deste. E o que indica é que se o discurso não torna manifesto o seu objeto, não cumpre sua função” (ARISTÓTELES, 2011, p.214), por isso deve-se, ainda de acordo com o filósofo, primar por um estilo que seja adequado ao seu tema.

Já com relação às partes do discurso e seu arranjo, temos que são essencialmente duas, a saber, a exposição do tema seguida da argumentação. Dentro dessa organização mais geral, o autor propõe também outros tipos de divisão do discurso dependendo da natureza do mesmo (deliberativo, forense ou demonstrativo) e de demandas geradas durante o discurso, como uma possível contestação, por exemplo. Um máximo de quatro partes é apontado por Aristóteles, sendo essas partes o prólogo, a exposição, a demonstração e o epílogo. Vale lembrar que, embora essa proposição aristotélica possa nos remeter a tão comum divisão em quatro parágrafos exigida, hoje, na produção de textos dissertativo-argumentativos escolares, não podemos estabelecer uma relação direta entre uma e outra já que Aristóteles apresenta apenas um modo de disposição das diferentes partes do discurso enquanto a determinação de que um texto tenha exatos quatro parágrafos impõe um limite de espaço para a argumentação, (de)limitando a escrita do sujeito-aluno .

Voltando para a "Retórica”, após termos nos debruçado ainda que sucintamente sobre seu conteúdo, podemos afirmar que, com esta obra, Aristóteles inaugura as bases teóricas da argumentação, a partir das quais, mais tarde, várias outras reflexões sobre o tema terão origem.

Também por esta razão, na posição de analistas do discurso, o fato de termos elegido a obra aristotélica para tratarmos da argumentação não se deu sem propósito, mas, antes, sendo 
constantemente afetadas pela Análise de Discurso, decidimos partir dessa obra por considerála um “discurso fundador” sobre o qual discorre Orlandi (1993a, p.24):

\begin{abstract}
Concluímos que é discurso fundador o que instala as condições de formação de outros, filiando-se à sua própria possibilidade, instituindo em seu conjunto um complexo de formações discursivas, uma região de sentidos, um sítio de significância que configura um processo de identificação para uma cultura, uma raça, uma nacionalidade.
\end{abstract}

Partindo, assim, da ideia de que a "Retórica” aristotélica funcionaria, então, como um discurso fundador (ORLANDI, 1993a), que seria responsável por cunhar uma nova tradição, inclusive de sentidos, consideramos que os muitos discursos que são tecidos sobre a argumentação podem ser considerados, então, desdobramentos dessa teoria. Por esse motivo, propomo-nos olhar, neste capítulo, para alguns conceitos-chave da "Retórica" e pensarmos como essa teoria desenvolve-se e quais poderiam ser suas contribuições para o ensino da argumentação, hoje, na escola. Lembramos, entretanto, que, embora essa teoria tenha sido base para muitos outros estudos, não constitui nosso objetivo tecer nenhum tratado de argumentação neste trabalho, mas apenas olhar sob a perspectiva discursiva para alguns conceitos da obra aristotélica, pensando em como esse saber poderia, então, ser trabalhado pela escola no momento destinado ao ensino do texto dissertativo-argumentativo.

Pensando, assim, na argumentação dentro do contexto escolar, não poderíamos deixar de mencionar a importância da retórica ${ }^{5}$ também como disciplina que, inclusive, compôs o currículo escolar em nosso país. Tanto que, prefaciando a obra "Retóricas de ontem e de hoje”, organizada por Mosca (2004), Klinkenberg, remontando as origens dessa disciplina aponta que ela, longe de ser tola, constituía “a primeira reflexão sistemática sobre os poderes da linguagem” (KLINKENBERG, apud MOSCA, 2004, p.11). O autor marca também que o surgimento da disciplina deu-se devido a uma necessidade da sociedade, que havia passado por profundas mudanças, principalmente no tocante às novas formas de resolver os conflitos de interesses que, agora, exigiriam não mais a força física, mas a força do simbólico ou, melhor dizendo, da linguagem, uma vez que esta configura-se como um “trabalho simbólico” (ORLANDI, 2008, p.16). Assim, de modo a conquistarem a adesão da coletividade e alcançarem seus objetivos, os indivíduos deveriam dominar os signos e a maneira de bem falar.

\footnotetext{
${ }^{5}$ Aqui o termo refere-se à disciplina chamada retórica que, durante muito tempo, fez parte do nosso currículo escolar.
} 
Tratando também do ensino da disciplina de retórica, dessa vez no contexto de Portugal e de seus domínios no final do século XVIII e início do século XIX, Pacheco (2010) igualmente aponta a conjuntura sócio-cultural da época como sendo a responsável pelas reformas no ensino das humanidades, mais especificamente no ensino das “Letras Humanas”. De acordo com o levantamento da autora, nomes como o de Antônio Nunes Ribeiro Sanches e Luís Antônio Verney, que, tendo viajado pela Europa e entrado em contato com outras realidades, denunciavam a situação de atraso de Portugal com relação aos países vizinhos, foram fundamentais na "mudança de mentalidade da sociedade lusitana e na consequente elaboração das reformas pombalinas que viriam a modificar o ensino da retórica” (PACHECO, 2010, p.1). Verney, por exemplo, em seu conhecido documento, o "Verdadeiro Método", colocava a retórica como uma arte que não deveria ser exclusiva “dos púlpitos e das cátedras”, mas que deveria ser pensada como algo útil para a vida pública de um modo geral, já que sua necessidade expandia-se pelas múltiplas relações que se estabeleciam no cotidiano. De acordo com Verney (apud PACHECO, 2010, p.8):

[...] por pouco que se examine, o que é Retorica, acharseá que é Arte de persuadir: e por consequencia que é a única coisa, que se-acha, e serve no comércio humano; e a mais necesaria para ele. Onde quem diz, que só serve para persuadir na cadeira, ou no-púlpito; conhece pouco, o que é Retórica. Confesso, que nos-púlpitos, e cadeiras faz a Retorica gala, de todas os seus ornamentos: mas nem se-limita neles: todo lugar é teatro para a Retorica. Nam agrada um livro, se nam é escrito com arte: nam persuade um discurso, se nam é formado com método. Finalmente uma carta, uma resposta, todo o exercício da língua necessita da-diresam da Retorica.

Essa nova visão sobre a retórica, em que a mesma ganha um caráter bastante utilitário, está presente, inclusive, nas instruções dadas na época para os professores da disciplina e foi também responsável por fazer com que esse saber fosse altamente valorizado dentro das escolas, no período em questão.

A partir também dos estudos de Razzini (2000, p.239), conseguimos reconhecer a força da retórica que, durante muito tempo, constituiu uma das partes do trivium - gramática, retórica e poética - que, mais tarde, fundiram-se e transformaram-se na disciplina de língua portuguesa. No entanto, não estamos falando ainda do momento que contempla o ensino da produção de textos dissertativo-argumentativos como conhecemos hoje, até mesmo porque, em seu detalhado estudo sobre a história da disciplinarização, Razzini (2000, p.238) aponta como foram paulatinas as mudanças que deram origem ao ensino de língua portuguesa e como o ensino da redação e da composição em gêneros retóricos - dissertação e argumentação constituiu um dos últimos objetos de ensino dentro dessa disciplina. 
Sabemos ainda, de acordo com Rojo (2008, p.84), que "não é pela via direta da apropriação das ideias aristotélicas que os gêneros poéticos e retóricos vão adentrar a escola”, mas, antes, esses saberes passam por um processo de didatização que, ainda segundo a autora, é responsável por construir objetos transdisciplinares complexos e, funcionando como um filtro, refrata a ideia original.

Além disso, há que se considerar também o papel dos materiais didáticos dentro do processo de didatização dos objetos de ensino. Assim, ao remontar um pouco da história da disciplina de língua portuguesa na escola, Soares (2002, p.164) afirma que até aproximadamente 1940, dois tipos de manuais escolares prevaleciam no ensino da leitura, gramática e composição, a saber, as antologias (ou seletas de textos) e as gramáticas. De acordo com Batista (1999, p.552), essas seletas, que em geral reuniam textos de autores consagrados, permitiam uma maior autonomia do professor, uma vez que, não apresentando exercícios ou atividades dirigidas diretamente aos alunos, delegava ao docente o papel de propor o trabalho com os textos e sugerir acréscimos ou outras leituras.

Mais tarde, analisando as mudanças que foram ocorrendo, no âmbito escolar, a partir da década de 1960, Rojo (2008, p.87) aponta que “em lugar das obras de referência como antologias, seletas e gramáticas, cria-se um novo tipo de material didático de apoio à prática docente que, propositalmente, interfere na autonomia do professorado”. É a partir, então, desse novo tipo de material, que conhecemos hoje como livro didático, que vários gêneros textuais entram na escola e, já que é nosso foco nesta pesquisa, destacamos aqui também a entrada dos textos midiáticos. Ainda segundo Rojo (2008, p.88):

Embora já não se fale em gêneros - possivelmente porque o que adentra a escola já não são principalmente os gêneros poéticos ou retóricos, da esfera literária ou política/jurídica/escolar-acadêmica -, o que acontece é a progressiva ampliação de gêneros de outras esferas (jornalística, publicitária, midiáticas, digital, etc.) que começam a adentrar as escolas; gêneros escolarizados que passam a disputar espaço com a "poética” e os textos literários.

Por outro lado, como aponta ainda esta autora, permanecem na escola tanto a narração quanto a dissertação; porém, agora, como atividades de composição unicamente escolares, que não trazem discussões nem sobre a "Poética”, nem sobre a "Retórica”. Confirmamos, assim, que não é pela assimilação das teorias aristotélicas que o gênero argumentativo entra na escola; entretanto, como entendemos que não se deve silenciar (ORLANDI, 2007a) a influência aristotélica, à semelhança de Rojo (2008, p.82), somos levadas a nos questionar sobre o 
tratamento dado a essa teoria e sobre as práticas didáticas que ela sustenta ou, pensando em sua ausência nos materiais didáticos que encontramos na atualidade, poderia sustentar.

Retomando, então, Aristóteles, sabemos que um dos principais propósitos da "Retórica” consiste em promover a participação ética e eficaz do cidadão no cotidiano da polis. Destacamos aqui a ética, pois, conforme Aristóteles (2011, p.42):

A retórica é útil porque o verdadeiro e o justo têm naturalmente mais valor do que os seus opostos. O resultado é que se os julgamentos não forem proferidos como devem ser, o verdadeiro e o justo estarão necessariamente comprometidos, resultado censurável a ser atribuído aos próprios oradores.

Por essa razão, sabemos que não apenas o domínio dos meios de persuasão se faz importante, mas, acima disso, a própria "veracidade” do discurso vai condicionar a utilidade dos mecanismos retóricos. Em outras palavras, se levarmos em conta os preceitos aristotélicos, estaremos afirmando que ensinar argumentação não consiste apenas em fornecer ao aluno uma série de técnicas, treinando-o para o convencimento do outro, mas, para além disso, o ensino da argumentação constitui solo fértil para a formação de um cidadão crítico, ético e hábil para exercer bons julgamentos diante das questões que lhe são colocadas, dentro e fora da escola.

Nesse sentido, caberia um retorno aos propósitos da "Retórica” de modo que fosse permitido ao cidadão atual "participar, ética e politicamente, não mais da polis ou da ágora, mas de uma sociedade global de alto fluxo de informação, julgando não mais fatos e homens, mas discursos e linguagens” (ROJO, 2008, p.99) e que esse cidadão pudesse então, a partir disso, exercer seu poder de argumentação.

No que diz respeito a esse poder argumentar, cumpre aqui lembrarmos que, para a Análise de Discurso francesa, as estratégias argumentativas que visam à persuasão apresentamse sutis, não sendo, portanto, superpostas às estruturas da língua, mas, pelo contrário, "só se manifestam à medida que a própria organização da língua é condicionada por essa necessidade de agir sobre outrem” (MAINGUENEAU, 1997, p.160). Maingueneau (1997, p.164-165) chama nossa atenção para o fato de que:

Na verdade, somos constantemente levados a falar de "sentido pretendido pelo locutor”, de "estratégias”, de “manobras”, etc., dirigidas para o destinatário. O linguista dificilmente pode dispensar este gênero de formulações, mas seria preciso não considerá-las em seu sentido estrito, nem representar a enunciação como uma partida de xadrez onde cada jogador calcula com toda a lucidez como vencer seu adversário. Se este modo de dizer não traz consequências para o estudo do uso comum da linguagem, é muito diferente para a AD, a qual trata com sujeitos dominados pelas imposições das formações discursivas e não com manipuladores que dominam do exterior suas enunciações. 
Por isso, ainda de acordo com o autor (1997), existe uma separação entre a "Retórica" e seus desdobramentos modernos e a Análise de Discurso, pois enquanto a primeira pressupõe um sujeito onipotente que faz uso dos mecanismos argumentativos para atingir um objetivo explícito, para a segunda "as formas de subjetividade estão implicadas nas próprias condições de possibilidade da formação discursiva” (MAINGUENEAU, 1997, p.160).

Mesmo com essa distinção, que poderia nos fazer pensar numa teoria linguística da argumentação, consideramos extremamente relevantes as contribuições aristotélicas, principalmente por serem, elas, uma das primeiras responsáveis por situar a argumentação dentro de um campo teórico. Além disso, entendendo a argumentação enquanto prática discursiva, sabemos que, mesmo que não possamos considerá-la como "prática dos sujeitos” (PÊCHEUX, 1995, p.214, grifo nosso), pela própria Análise de Discurso somos levadas à ideia de que, ao se inscrever em determinada prática, o sujeito é, de acordo com Pêcheux (1995), interpelado em “sujeito-responsável” pelo seu dizer. Daí podermos dizer que todo sujeito, ocupando a posição de quem argumenta, configura-se como sujeito propenso a fazer uso dos recursos retóricos descritos por Aristóteles.

Temos ainda, de acordo com a "Retórica” aristotélica (2011, p.45), que um discurso para que seja persuasivo, deve levar em conta três elementos, quais sejam, o caráter do orador (ethos), as disposições do auditório (pathos) e o discurso (logos). Assim, pode-se persuadir pelo caráter quando o orador, através de seu discurso, inspira confiança, pela disposição quando os ouvintes são levados a certas emoções por meio do discurso e, finalmente, a partir do próprio discurso quando este último expõe a verdade ou o que aparenta ser a verdade, ou seja, o verossímil. Em todos os casos, vemos a importância do discurso e, embora Aristóteles, por diversas vezes, refira-se a discurso como aquilo que é proferido oralmente, entendemos que essa teoria também se aplica às formas escritas do argumentar, até porque, como bem aponta Orlandi, “a linguagem tende para a textualidade; em minhas palavras, tende a formular-se, darse corpo” (ORLANDI, 2001, p.17).

Aristóteles (2011, p.53) marca ainda que “dos três elementos que compõem o discurso - o orador, o assunto e a pessoa a que se dirige o discurso - é este último elemento, ou seja, o ouvinte, aquele que determina a finalidade e o objeto do discurso”. Indo além, de acordo com Rojo (2008, p.84): 
réplica ativa ou respondibilidade do discurso e do ouvinte e nos efeitos de sentido dos discursos. Assim é que fala, no livro segundo, de prazer, justiça/injustiça, virtude, igualdade, serenidade, inteireza, paixões, ira, amor, ódio, amizade/inimizade, vergonha, respeito, favor, indignação, inveja, fazendo os discursos circularem num ambiente de língua viva que alimenta as paixões humanas.

É dessa maneira, portanto, que, a partir da Análise de Discurso, podemos lançar um olhar sobre as paixões aristotélicas, pois cuidar dos efeitos de sentido de um discurso, preocupando-se em despertar determinadas emoções no interlocutor e, assim, convencê-lo, requer que o locutor assuma a posição de autor e também a posição de quem argumenta.

Em comunicação pessoal, em 05/abril/2013, formulamos que a argumentação deve ser entendida como um espaço discursivo que o sujeito pode ou não ocupar. Ao ocupar esse espaço, o sujeito assume a responsabilidade pelo dizer, assume um posicionamento acerca de determinado objeto discursivo; ele trabalha com o já-dito, com o interdiscurso e, a partir disso, constrói estratégias persuasivas que sustentam sua defesa, no intradiscurso. Essa sustentação está relacionada ao poder político-ideológico e não apenas ao poder/saber usar a língua adequadamente (PACÍFICO; LEMES, 2013) ${ }^{6}$.

Assim, assumindo a posição discursiva de quem argumenta, o sujeito pode fazer uso de estratégias como, por exemplo, a metáfora, entendida aqui como “a capacidade de perceber semelhanças” (MOSCA, 2004, p.35). Tal recurso constitui-se argumentativo na medida em que seu uso ajuda na construção dos enunciados, possibilitando que o locutor, na busca por atingir o consenso e a unanimidade, recorra a estereótipos e a lugares-comuns já reconhecidos pela voz da coletividade. Nesse caso, o sujeito estaria fazendo uso do que Fontanier chama de "metáfora de uso” (apud MOSCA, 2004, p.38).

Embora a funcionalidade desse tipo de metáfora não seja desprezada pelo autor acima, outra possibilidade colocada seria o uso da “metáfora de invenção" (FONTANIER apud MOSCA, 2004, p.38), ou seja, recurso que permite ao locutor propor um diferente modo de olhar para o objeto discursivo, rompendo, por vezes, com possíveis estereótipos, criando, assim, no interlocutor um efeito "surpresa” que, se bem feito, sustentará com ainda mais força a argumentação.

Vale aqui colocar que, assim como Pacífico (2002, p.46-47):

\footnotetext{
${ }^{6}$ Essa citação não consta nas referências desse trabalho por tratar-se de uma formulação produzida em comunicação oral realizada em reunião para a orientação desta pesquisa.
} 
Entendemos que a "metáfora de invenção” é usada pelo sujeito que assume a função-leitor, que reflete sobre o verossímil, que procura compreender os sentidos prováveis, que podem ou não ser aqueles, isto é, o sujeito não fica preso a "cânones”. Em contrapartida, a "metáfora de uso" é encontrada nos textos do sujeito que assume a fôrma-leitor, pois aqui, o sentido já está cristalizado por determinada formação discursiva e o sujeito o reproduz, pois está preso ao "uso" e não envolvido no contexto. Aqui, o sujeito não reflete sobre aquilo que parece verdadeiro, porque acredita que o que lhe dizem é a verdade (ilusão $n^{\circ} 2$ ).

Desse modo, a "metáfora de uso" comprometeria a argumentatividade do texto, uma vez que os sentidos trazidos por esse tipo de recurso seriam já previstos pelo interlocutor e poderiam, assim, ser facilmente rebatidos. Por outro lado, a “metáfora de invenção” possibilita que se alcance a finalidade do discurso argumentativo que é, também, a de "incitamento e de sedução” do sujeito leitor (MOSCA, 2004, p.40), despertando nesse último as emoções (ARISTÓTELES, 2011) que o levarão a compactuar com as ideias do locutor.

Outra estratégia argumentativa, que pode ser usada pelo sujeito que assume a posição de autor e preocupa-se com a produção de sentidos em seu texto, é o mecanismo de antecipação, segundo o qual, "todo sujeito tem a capacidade de experimentar, ou melhor, de colocar-se no lugar em que seu interlocutor 'ouve’ suas palavras” (ORLANDI, 2007b, p.39), antecipando os sentidos que suas palavras poderão produzir e buscando controlar tais sentidos.

Sobre a relação que o mecanismo de antecipação estabelece com a argumentação, Orlandi (2007b, p.39) entende que:

Esse mecanismo regula a argumentação, de tal forma que o sujeito dirá de um modo, ou de outro, segundo o efeito que pensa produzir em seu ouvinte. Esse espectro varia amplamente desde a previsão de um interlocutor que é seu cúmplice até aquele que, no outro extremo, ele prevê como adversário absoluto. Dessa maneira, esse mecanismo dirige o processo de argumentação visando seus efeitos sobre o interlocutor.

Notamos, então, que é tarefa daquele que argumenta tentar controlar os sentidos de seu texto e ainda buscar prever possíveis contra-argumentos para já contrapô-los. Isso implica que o autor do texto argumentativo deve colocar-se tanto na posição de escritor como na de leitor, de modo a antecipar os efeitos de sentido do seu texto. Ainda de acordo com Orlandi (2007b, p.40), esse tipo de mecanismo apoia-se nas formações imaginárias, já vistas anteriormente, pois o que vale nesse “jogo persuasivo” são as imagens que locutores e interlocutores têm de si e também do referente.

Temos também em Aristóteles, mesmo como pressuposto, essa necessidade do envolvimento do sujeito com o referente, ou seja, com o objeto discursivo. Assim, levando em 
conta a importância do sujeito construir uma imagem do referente, ou seja, do tema sobre o qual irá dissertar de maneira argumentativa, somos levadas a pensar em como essa imagem e, consequentemente, o ponto de vista do sujeito-aluno sobre determinada questão pode ser formado quando só lhe é permitido o contato com um texto jornalístico, cuja leitura proposta pelo livro didático apresenta, ilusoriamente, um sentido único, apontado como “correto” sobre determinado assunto.

Por essa razão, entendemos que é de crucial valor o aluno ter acesso ao arquivo (PÊCHEUX, 2010), conceito sobre o qual discorremos no capítulo anterior e que implica fornecer ao aluno uma série de textos sobre o tema em questão, de modo que ele possa entrar em contato com diversos sentidos produzidos sobre o objeto discursivo.

Faz-se ainda necessário o engajamento do professor nesse processo, pois cabe a ele, neste caso, a partir desse “campo de documentos pertinentes” (PÊCHEUX, 2010, p.51), promover condições para que se instale o “discurso polêmico” (ORLANDI, 2003, p.154) em sala de aula, de modo que os sujeitos-alunos possam também realizar uma leitura crítica desses “documentos”. Isso, por sua vez, permitirá que o aluno consiga refletir sobre o objeto discursivo e sustentar argumentos para defender seu ponto de vista.

Como vimos, as técnicas persuasivas só podem ser utilizadas se houver, antes, um espaço de diferença de opiniões, de contraposições de ideias e esse espaço torna-se, então, condição para que haja a argumentação. Nesse sentido, tratando também das contribuições aristotélicas, Mosca (2004, p.20) afirma que:

O ponto fundamental da doutrina aristotélica, no que toca à Retórica, reside em considerá-la do domínio dos conhecimentos prováveis e não das certezas e das evidências, os quais caberiam aos raciocínios científicos e lógicos. Por essa razão, o seu campo é o da controvérsia, da crença, do mundo da opinião, que se há de formar dialeticamente, pelo embate das ideias e pela habilidade no manejo do discurso.

Em contrapartida, vemos que a escola, por meio do livro didático, valoriza o consenso (PACÍFICO, 2002, p.48) e sendo assim, o aluno não consegue argumentar, ele só é argumentado por um discurso "pronto”, “fechado” e que o mantêm preso a determinados sentidos. Por isso a importância de que se instale o discurso polêmico (ORLANDI, 2003) em sala de aula, de modo a propiciar aos alunos condições para que eles exerçam seu poder de argumentação.

Tendo em vista, então, que a argumentação configura-se como um campo teórico riquíssimo, repleto de conceitos e de mecanismos, como foi possível observar até o momento, 
resta-nos uma pergunta que, mesmo soando retórica, constitui um dos pontos de partida para as análises que seguirão: essa teoria chega até a escola? 


\section{CAPÍTULO IV}

\section{A argumentação e o discurso jornalístico no livro didático: um cruzamento de vozes}

Que faremos destes jornais, com telegramas, notícias, anúncios, fotografias, opiniões...?

Caem as folhas secas sobre os longos relatos de guerra: e o sol empalidece suas letras infinitas.

Que faremos destes jornais, longe do mundo e dos homens? Este recado de loucura perde o sentido entre a terra e o céu.

De dia, lemos na flor que nasce e na abelha que voa; de noite, nas grandes estrelas, e no aroma do campo serenado.

Aqui, toda a vizinhança proclama convicta:

"Os jornais servem para fazer embrulhos".

E é uma das raras vezes em que todos estão de acordo.

(Cecília Meireles - Jornal, longe)

Ao abrirmos a primeira parte de nossas análises, que terá como objeto as seções do livro didático de língua portuguesa do Ensino Médio dedicadas à produção textual, mais especificamente àquelas que tratam da produção de textos dissertativo-argumentativos, somos levadas primeiramente a uma reflexão sobre as razões pelas quais o ensino da argumentação parece estar delegado quase que exclusivamente aos anos finais do Ensino Médio e quais as implicações disso para a escola e para os alunos.

Em pesquisa anterior, realizada no ano de 2010, entramos em contato com livros didáticos de língua portuguesa que vinham sendo utilizados no Ensino Fundamental e, embora não fosse esse nosso foco naquele momento, não nos passou despercebido o fato de que, nos três livros analisados, não foi possível encontrar seções específicas destinadas ao ensino de 
textos argumentativos, principalmente nos livros utilizados nos primeiros anos desse período escolar. Consideramos lesivo esse apagamento da argumentação, pois como marca Pacífico (2002, p.49-50), “para que o sujeito estivesse preparado para argumentar seria necessário que desde as primeiras séries ele já fosse instalado no discurso polêmico, que permitisse discutir o objeto discursivo, discordar da visão do outro e saber como fazê-lo”.

Se, no entanto, os alunos não são nem ao menos apresentados a essa outra modalidade de texto e se as condições acima citadas não são oferecidas aos sujeitos-alunos, é bem possível que haja estranhamento por parte desses estudantes quando, apenas no Ensino Médio e, posteriormente, no Ensino Superior lhes é cobrado o domínio desse tipo de texto.

Além disso, o apagamento dessa teoria sobre o argumentar, nos anos correspondentes ao Ensino Fundamental, ocorre também em função de uma predominância, na escola, do ensino de gêneros narrativos, cuja principal função, de acordo com Tfouni (1995, p.73), seria “organizar, através da linguagem, nossas interações, conhecimento e experiências sobre (no) mundo e com o Outro”. Ainda em consonância com Tfouni (1995, p.73-74):

\footnotetext{
O discurso narrativo aparece como o lugar privilegiado para a elaboração da experiência pessoal; para a transformação do real em realidade, por meio de mecanismos linguístico-discursivos, e também para a inserção da subjetividade (entendida aqui, do ponto de vista discursivo, como o lugar que o sujeito do discurso pode ocupar para falar de si próprio, de suas experiências, conhecimento do mundo, sentimentos, ou mais sucintamente, entendida como a forma pela qual o sujeito organiza sua simbolização particular).
}

Desse modo, ao privilegiar o texto narrativo no Ensino Fundamental, a escola, esquivando-se daquilo que é sua tarefa, garantiria ao aluno o lugar "confortável” de quem apenas fala da própria experiência, de quem narra os acontecimentos de “suas férias” sem precisar preocupar-se com a sustentação de um ponto de vista, com a objetividade ou com o uso de mecanismos específicos como aqueles exigidos para a construção de um texto argumentativo.

Notamos, assim, desde nossa pesquisa de iniciação científica, que o ensino sobre a argumentação é, normalmente, adiado para os anos do Ensino Médio, o que, além de sugerir que ele seja dispensável em fases anteriores, reduz esse tipo textual ao estado de utilidade, como se os conhecimentos sobre o argumentar só fossem necessários no período que antecede o vestibular.

Para sabermos se isso, de fato, acontece, damos início às nossas análises, lembrando que trabalharemos com recortes uma vez que, para a Análise de Discurso, "não é a extensão que delimita o que é um texto” (ORLANDI, 2007b, p.69), mas, sim, o fato do recorte ser referido à 
um discurso. Reiteramos, ainda, que todos os recortes analisados nesse capítulo pertencem a livros didáticos que estão sendo utilizados atualmente, no terceiro ano do Ensino Médio, em escolas públicas de Ribeirão Preto. Para fins práticos, nominaremos alfabeticamente os recortes, sendo esse primeiro chamado de recorte A.

Recorte A

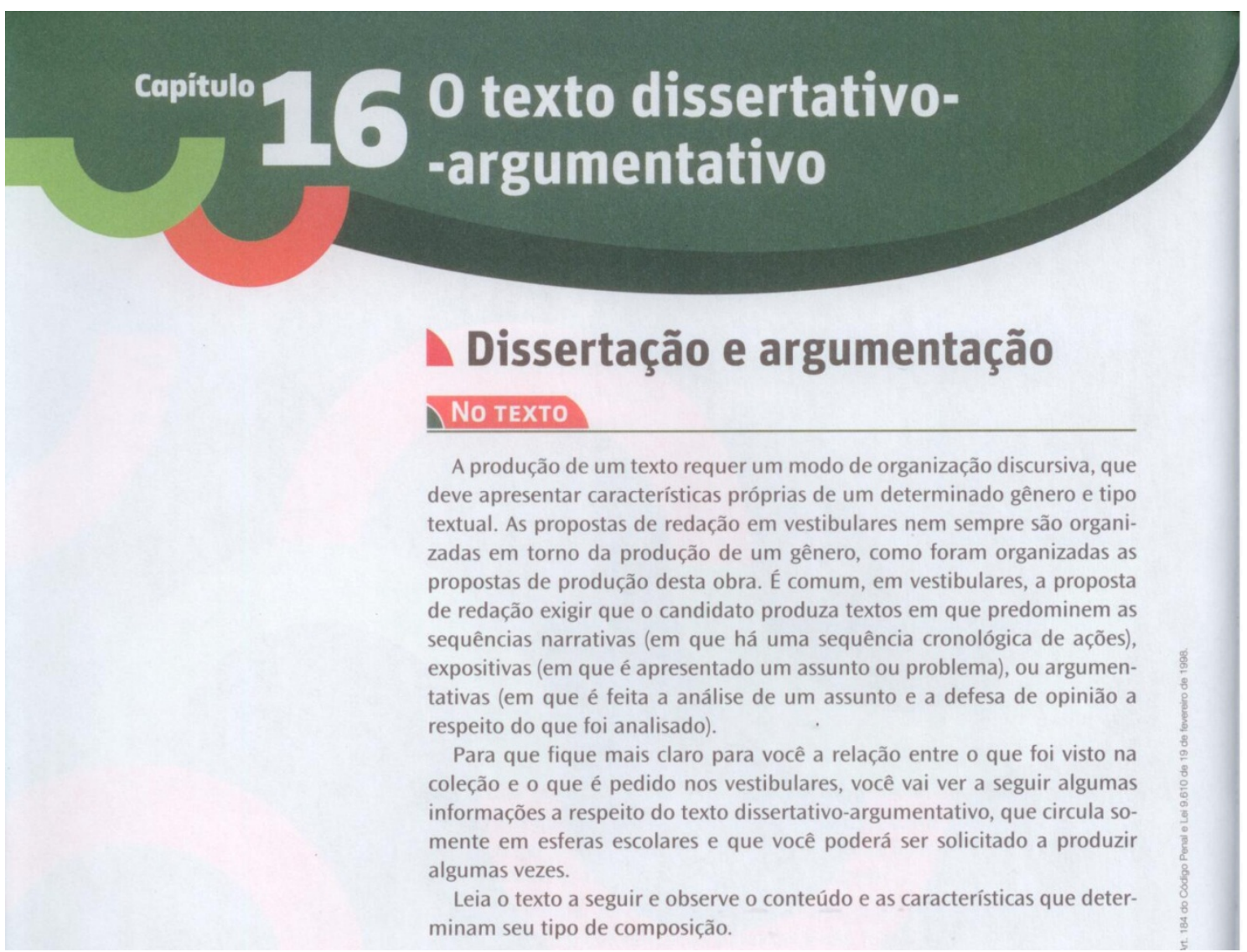

O próprio título do livro didático do qual esse nosso primeiro recorte foi retirado já se configura como matéria para nossas análises. O livro de língua portuguesa, chamado “Português: literatura, gramática e produção de texto”, já produz em seu título um efeito de sentido de fragmentação do ensino de língua, como se devesse existir uma separação no ensino da literatura, da gramática e da produção de texto, do que duvidamos.

O recorte acima traz um texto que abre o capítulo do livro didático destinado à produção textual dissertativo-argumentativa. Analisando também os volumes I e II desta coleção, utilizados, respectivamente, no primeiro e segundo anos do Ensino Médio da mesma escola, notamos que apenas no terceiro volume o texto dissertativo-argumentativo é apresentado aos sujeitos-alunos, o que aponta para o que já vínhamos discutindo acima, ou seja, o ensino tardio 
desse importante conteúdo e seu adiamento, às vezes, para o último ano do Ensino Médio, como no caso que estamos analisando.

Voltando para o recorte, temos um texto que se inicia com alguns comentários a respeito da organização discursiva exigida em determinado gênero e tipo textual, seguida de um esclarecimento sobre os tipos de texto que são comumente cobrados nos exames vestibulares. Assim, já na abertura deste capítulo do livro didático, percebemos uma forte interferência das questões que envolvem o exame vestibular no contexto de ensino da argumentação, como se a função de tal ensino fosse apenas o bom desempenho nas provas que selecionam candidatos para o ingresso nas universidades, o que podemos notar nos seguintes trechos do recorte A:

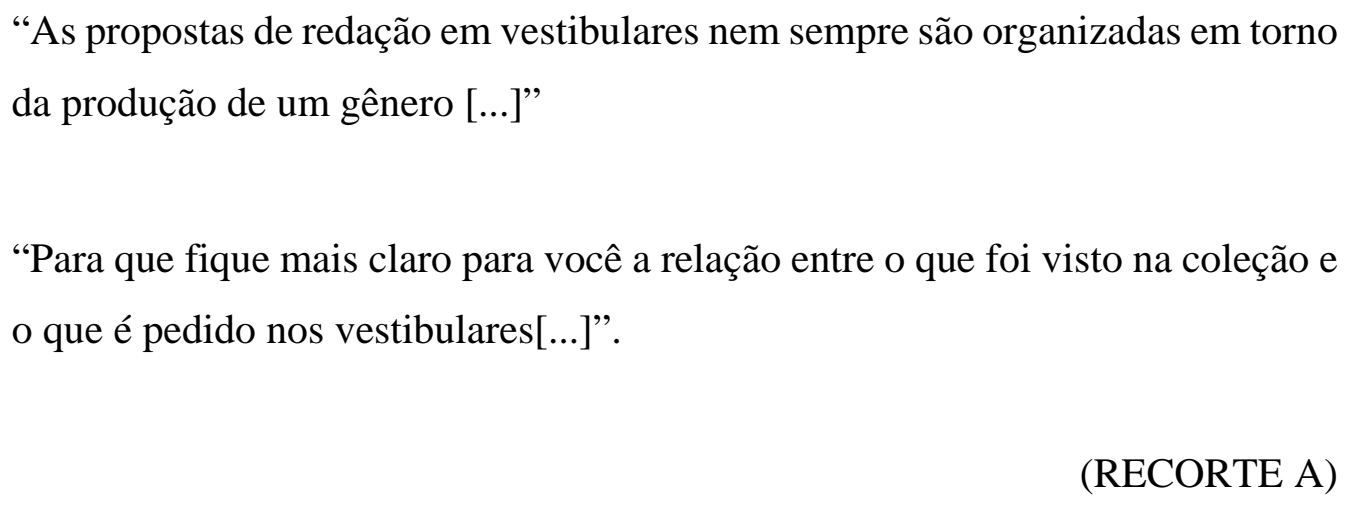

Dessa maneira, o livro didático desconsidera a importância do argumentar como uma prática social; como direito do homem; como uma arte; como a possibilidade de disputa dos sentidos. Conforme vimos no capítulo anterior, Aristóteles já trazia para o cerne das discussões acerca da retórica a sua importância na vida de todo e qualquer indivíduo, para realizar “a própria defesa e a acusação dos outros” (ARISTÓTELES, 2011, p.39). Ao negar as possíveis relações que os alunos podem construir com a argumentação, o livro reduz seu ensino a um caráter meramente utilitário, ou seja, o vestibular.

Entretanto, apontando a importância da argumentação, Koch (2011, p.17) ressalta que:

A interação social por intermédio da língua caracteriza-se, fundamentalmente, pela argumentatividade. Como ser dotado de razão e vontade, o homem, constantemente, avalia, julga, critica, isto é, forma juízo de valor. Por outro lado, por meio do discurso - ação verbal dotada de intencionalidade - tenta influir sobre o comportamento do outro ou fazer com que compartilhe determinadas de suas opiniões. É por esta razão que se pode afirmar que o ato de argumentar, isto é, de orientar o discurso no sentido de determinadas conclusões, constitui o ato linguístico fundamental, pois a todo e qualquer discurso subjaz uma ideologia, na acepção mais ampla do termo. 
Embora a perspectiva da autora supracitada se distancie da nossa na medida em que, como analistas do discurso, não consideramos a intencionalidade como algo que afeta diretamente o discurso, concordamos com a relevância da argumentação no cotidiano dos sujeitos e, também por isso, defendemos seu ensino na escola.

Dando sequência ao recorte A, no mesmo livro didático - "Português: literatura, gramática e produção de texto” -, temos o recorte B. 


\section{Recorte B}

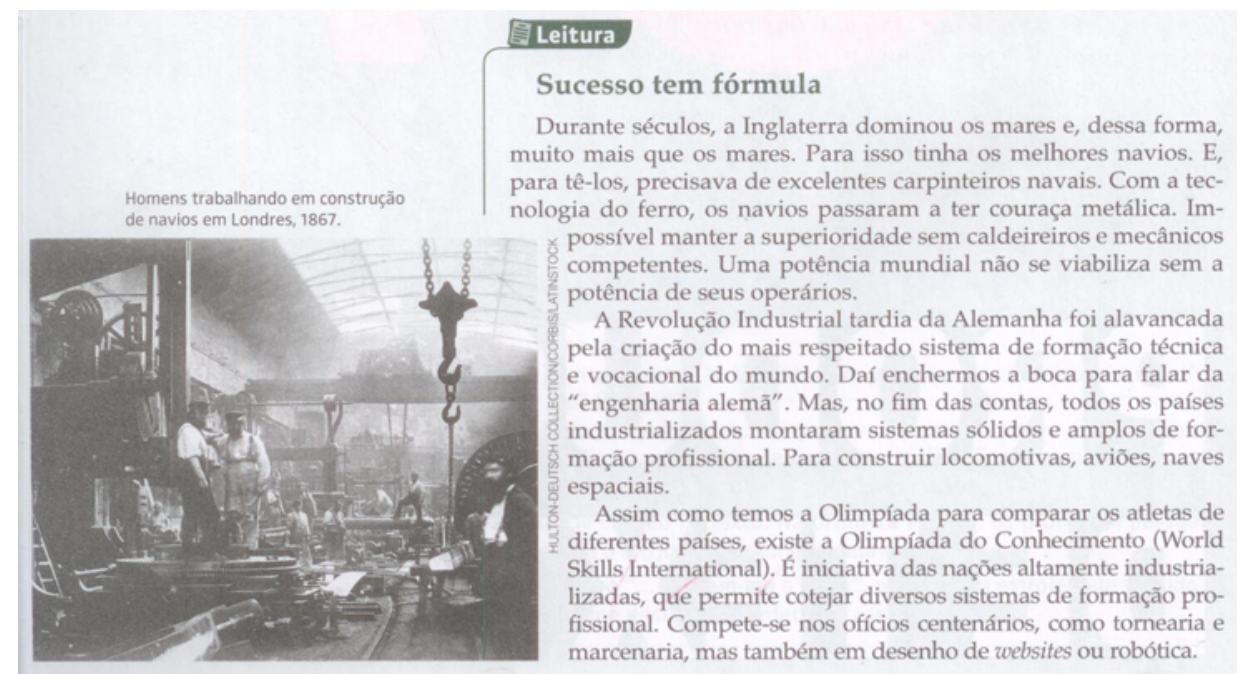

Em 1982, um país novato nesses misteres se atreveu a participar dessa Olimpíada: o Brasil, por meio do Senai. E lá viu o seu lugar, pois não ganhou uma só medalha. Mas em 1985 conseguiu chegar ao $13^{\circ}$ lugar. Em 2001 saltou para o sexto. Aliás, é o único país do Terceiro Mundo a participar, entra ano e sai ano.

Em 2007 tirou o segundo lugar. Em 2009 tirou o terceiro, competindo com 539 alunos, de sete estados, em 44 ocupações. É isso mesmo, os graduados do Senai, incluindo alunos de Alagoas, Goiás e Rio Grande do Norte, conseguiram colocar o Brasil como o segundo e o terceiro melhor do mundo em formação profissional. Não é pouca porcaria para quem, faz meio século, importava banha de porco, pentes, palitos, sapatos e manteiga!

E que, praticamente, não tinha centros de formação profissional.

Deve haver um segredo para esse resultado que mais parece milagre, quando consideramos que o Brasil, no Programa Internacional de Avaliação de Alunos (Pisa), por pouco escapa de ser o último. Mas não há milagres nem tapetão. Trata-se de uma fórmula simples, composta de quatro ingredientes.

Em primeiro lugar, é necessário ter um sistema de formação profissional hábil na organização requerida para preparar milhões de alunos e que disponha de instrutores competentes e capazes de ensinar em padrões de Primeiro Mundo. Obviamente, precisam saber fazer e saber ensinar. Diplomas não interessam (quem sabe nossa educação teria alguma lição a tirar dar?).

Em segundo lugar, cumpre selecionar os melhores candidatos para a Olimpíada. O princípio é simples (mas a logística é diabolicamente complexa). Cada escola do Senai faz um concurso, para escolher os vencedores em cada profissão. Esse time participa então de uma competição no seu estado. Por fim, os times estaduais participam de uma Olimpíada nacional. Dali se pescam os que vão representar o Brasil. É a meritocrácia em ação.

Em terceiro lugar, o processo não para af. $\mathrm{O}$ time vencedor mergulha em árduo período de preparação, por mais de um ano. Fica inteiramente dedicado às tarefas de aperfeiçoar seus conhecimentos da profissão. É acompanhado pelos mais destacados instrutores do Senai, em regime de tutoria individual.

Em quarto, é preciso insistir, dar tempo ao tempo. Para passar do último lugar, em 1983, para o segundo, em 2007, transcorreram 22 anos. Portanto a persistência é essencial.

Essa quádrupla fórmula garantiu ò avanço progressivo do Brasil nesse certame no qual apenas cachorro grande entra. Era preciso ter um ótimo sistema de centros de formação profissional. Os parâmetros de qualidade são determinados pelas práticas industriais consagradas, e não por elucubrações de professores. Há que aceitar a ideia de peneirar sistematicamente, na busca dos melhores candidatos. E a crença na meritocracia, muito ausente no ensino acadêmico. Finalmente, é preciso muito esforço, muito mesmo. Para passar na frente de Alemanha e Suíça, só suando a camisa. E não foi o ato heroico, mas a continuidade que trouxe a vitória.

A fórmula serve para toda competição: qualidade valorizada, seleção dos melhores, prática obsessiva e persistência. Quem aplicar essa receita terá os mesmos resultados.

CASTRO, Cláudio de Moura. Veia, São Paulo, n. 2.153, p. 22, 24 fev 2010. 
Nesse recorte que, como expusemos, é uma continuação do texto apresentado no recorte A, o livro didático apresenta um texto jornalístico retirado de uma revista de ampla circulação em nosso país, muito conhecida por tratar, principalmente, de assuntos políticos, de maneira tendenciosa e com uma visão considerada “de direita”. O livro apresenta tal texto para o aluno chamando-o para a leitura e pedindo que ele "observe o conteúdo e as características que determinam seu tipo de composição".

Nosso primeiro estranhamento encontra-se no fato de que antes de apresentar o texto jornalístico, o autor do livro didático afirma, ainda no recorte A, que colocará o aluno em contato com "algumas informações a respeito do texto dissertativo-argumentativo, que circula somente em esferas escolares”.

Criando assim, a expectativa de que discorrerá sobre alguma teoria e trabalhará, a partir daquele momento, com alguma materialidade que pertença ao domínio do científico, a um campo de saberes elevados que, por esta razão, só seja acessível, ao aluno, no ambiente escolar. Todavia, isso não ocorre e o que o leitor encontra é o texto jornalístico apresentado acima, de Claudio de Moura Castro, como se por si só a produção do jornalista ensinasse o aluno a produzir um texto dissertativo-argumentativo.

Sabemos que a escola é legitimada pela sociedade como o lugar privilegiado para que o aluno entre em contato com saberes que ultrapassam o âmbito do senso comum. Garcia (2008, p.11) aponta ainda que o próprio discurso da escola é o de que "a ela caberia a socialização do conhecimento" o que, por sua vez, "significaria que na escola estaria guardado o conhecimento, e tudo que não fosse aprendido na escola seria não-conhecimento” (GARCIA, 2008, p.11). Importante ressaltar que, embora não estejamos de acordo com essa noção que reduz a "nãoconhecimento" tudo que circula fora da escola, entendemos o papel da instituição escolar como o de principal difusora do saber científico e, indo além, acreditamos que isso represente uma de suas maiores responsabilidades. Por essa razão é que nos preocupa o modo como o discurso jornalístico vem circulando na escola e seu uso para o ensino de um conteúdo tão importante como a argumentação.

Voltando, então, nosso olhar para o texto jornalístico que compõe nosso recorte B, percebemos que ele oferece muita matéria discursiva para nossas análises. Mesmo assim, focaremos, aqui, naquilo que nos interessa enquanto investigadoras de como se processa (ou não) o ensino da argumentação no livro didático e o analisaremos, maiormente, como parte de uma proposta de ensino.

Assim, enquanto texto que compõe a seção do livro dedicada ao ensino da dissertação argumentativa, o discurso jornalístico presente no recorte $\mathrm{B}$, por tratar-se de um artigo de 
opinião, possui uma tessitura própria que o caracteriza como um texto midiático. Logo, embora haja sim a exposição de uma opinião e a sustentação de um ponto de vista, há traços marcantes que o diferenciam, por exemplo, de um texto argumentativo que teria como objetivo a aprovação no exame vestibular. Para esclarecer a questão, voltemos a atenção para algumas formulações presentes no texto jornalístico analisado no Recorte B:

"Daí enchermos a boca para falar da engenharia alemã”

“Em 2007 tirou o segundo lugar. Em 2009 tirou o terceiro, competindo com 539 alunos, de sete estados, em 44 ocupações. É isso mesmo, os graduados do Senai, incluindo alunos de Alagoas, Goiás e Rio Grande do Norte, conseguiram colocar o Brasil como o segundo e o terceiro melhor do mundo em formação profissional. Não é pouca porcaria para quem, faz meio século, importava banha de porco...”

“Essa quádrupla fórmula garantiu o avanço progressivo do Brasil nesse certame no qual apenas cachorro grande entra”

"Finalmente, é preciso muito esforço, muito mesmo. Para passar na frente de Alemanha e Suiça, só suando a camisa”

(RECORTE B)

Sabemos que a construção de um texto midiático caminha na direção de um propósito maior que é, nesse caso, a venda da revista e, para isso, apropria-se de recursos que visam a criar um efeito de proximidade com o leitor, de modo que esse último identifique-se com aquilo que lê. É o que acontece nas formulações acima transcritas. Em uma delas, por exemplo, o jornalista faz uso de uma expressão característica da oralidade a fim de criar um efeito de “conversa”, como se o leitor tivesse expressado sua surpresa com as boas colocações do Brasil no ranking da Olimpíada do conhecimento e o autor do texto precisasse reafirmá-las dizendo: “É isso mesmo”. Além disso, o jornalista utiliza ditos populares conhecidos como "encher a boca para falar de algo”, “não é pouca porcaria”, “ só cachorro grande entra” e “ter que suar a camisa” criando, assim, um efeito de intimidade com o leitor. 
Não temos aqui a intenção de criticar a linguagem utilizada pelo jornalista; entretanto, entendemos que o texto midiático, não raras vezes, apresenta-se com especificidades que podem inviabilizar seu uso, na escola, como modelo para a produção do texto dissertativoargumentativo. Este último, como sabemos, é altamente valorizado nos exames vestibulares mais reconhecidos em nossa região, sendo que de três universidades que estão entre as mais procuradas de nosso estado, duas o solicitam indispensavelmente em suas provas para ingresso. Além disso, vimos, por meio do recorte A, que a própria perspectiva de trabalho do livro didático em questão dá lugar de destaque para o vestibular, o que nos leva a pensar, então, quão incoerente se faz a presença de um texto jornalístico como o que estamos analisando, uma vez que sua linguagem foge, algumas vezes, da “formalidade” exigida por esses vestibulares.

Por outro lado, embora não apoiemos o ensino da argumentação apenas para fins de aprovação no vestibular, acreditamos que se é intenção maior da escola fazer com que seus alunos ingressem nas universidades, seria, então, muito mais pertinente e produtivo para os alunos terem contato com textos argumentativos produzidos, talvez, por outros estudantes já aprovados nos vestibulares. Nesse sentido, uma coletânea das melhores redações elaboradas em vestibulares anteriores poderia também e, por que não dizer, melhor servir como exemplo para que os sujeitos-alunos vissem em funcionamento alguns dos operadores argumentativos bem usados e aprovados nos vestibulares.

Cabe frisar que não consideramos dispensável o ensino da teoria da argumentação. Ao contrário, encaramos como sendo fundamental esse contato para que haja possibilidade de assunção da autoria e, por conseguinte, que o sujeito argumente (PACÍFICO, 2002). Se, no entanto, essa teoria não chega na escola e, como poderemos ver a frente, o texto jornalístico é levado para a sala de aula e sua leitura é feita de maneira que não se questione nenhum dos sentidos ali presentes, como esperar do aluno a construção de um ponto de vista e sua sustentação?

Sobre isso, concordamos com Romão e Pacífico (2006, p.33), quando, analisando a construção dos sentidos nos diversos tipos de leitura, pontuam que:

\footnotetext{
Diante de tais considerações, observamos que há uma diferença entre a leitura escolar e a leitura de outros textos, como os da mídia, por exemplo, pois, enquanto a primeira é dirigida a um público específico; a segunda, relacionada à mídia, é acessível a um público bastante heterogêneo, em que o conhecimento do leitor é o principal componente diferenciador da leitura.
}

Ao mesmo tempo, as autoras alertam para a situação da escola tradicional onde só é permitida a leitura parafrástica, ou seja, aquela que privilegia um único sentido e promove a 
repetição do mesmo entre os sujeitos-alunos. Vemos da mesma forma, o modo como a escola trabalha com a reprodução dos sentidos do discurso jornalístico, pois, na maioria das vezes, como as análises que seguem nos permitem observar, esses sentidos são privilegiados e legitimados, ilusoriamente, como "verdades absolutas".

De modo a esclarecer essa realidade, vejamos, no recorte C, como o mesmo livro didático propõe o trabalho com o texto jornalístico apresentado no recorte anterior: 


\section{Recorte C}

1 Com base no título, pode-se dizer que o autor emite uma opinião sobre o assunto abordado. Explique por quê.

a) No primeiro parágrafo, que frase praticamente sintetiza a ideia principal do texto? Esclareça sua resposta.

b) De que forma o autor reforça essa ideia nos dois primeiros parágrafos?

2 Segundo o texto, nos países onde há uma industrialização avançada, é realizada a Olimpíada do Conhecimento. Explique por que a competição entre os melhores profissionais tem favorecido o desenvolvimento desses países.

3 Do quarto ao sexto parágrafo, o autor analisa a participação do Brasil na Olimpíada do Conhecimento.

a) O que esse fato comprova, tendo em vista as opiniōes já apresentadas?

b) Por que o autor escolheu a conquista dos alunos do Senai para ilustrar seu ponto de vista sobre o sucesso?

4 Apesar de considerada simples, a chave para o sucesso apresenta várias etapas. Sintetize as ideias básicas de cada etapa.

5 No texto, o autor expōe suas opiniōes e, em seguida, defende seu ponto de vista analisando-o em detalhes. No último parágrafo, como ele conseguiu dar maior credibilidade às ideias apresentadas?

6 Responda, no caderno, e justifique sua resposta com base no texto. Esse texto é:

- narrativo, porque faz o relato de fatos que ocorrem em uma sequência cronológica de açōes.

- descritivo, porque há a caracterização de pessoas e de objetos, em um determinado momento.

- argumentativo, porque, além da exposição das ideias, há argumentos que defendem um ponto de vista.

- expositivo, porque ocorre uma exposição de ideias ou a análise detalhada de um tema.

7 o emprego adequado dos elementos de coesão, no texto dissertativo-argumentativo, é importante para que sua estrutura permita melhor compreensão das ideias.

a) No primeiro parágrafo, o autor introduz uma opinião e, em seguida, emprega uma expressão coesiva, nesta frase: "Para isso tinha os melhores navios". Escreva, no caderno, se ela expressa sentido de retificação, explicaçāo, justificativa, finalidade ou confirmação e esclareça sua resposta.

b) No segundo parágrafo, que sentido introduz o elemento de coesão mas? Por quê?

8 Após uma exposição inicial dos fatos que fizeram da Inglaterra, Alemanha e de outros países industrializados grandes potências, o autor analisa a participação do Brasil na Olimpíada do Conhecimento.

a) Que fatores ele mencionou para mostrar o avanço das equipes de profissionais brasileiros nessa disputa?

b) Portanto, qual é o ponto de vista defendido pelo autor em relação ao assunto abordado?

9 O texto argumentativo apresenta dados, fatos e testemunhos para reforçar o ponto de vista do autor.

a) No texto, quais são os dados mais relevantes que dão consistência às argumentaçōes?

b) Que fatos foram mencionados para persuadir o leitor de que as ideias expostas são verdadeiras?

10 O autor empregou determinados recursos no desenvolvimento de sua opiniāo de que existe uma fórmula para o sucesso. Escreva, no caderno, quais dos seguintes recursos argumentativos ele usou: comparação, enumeraçâo, causa, consequência, citação, exemplificaçẫo.

11 No último parágrafo, ocorre a conclusão sobre o assunto enfocado. - Explique como o autor concluiu as ideias desenvolvidas.

12 Responda no caderno.

a) Em que contexto de circulação foi publicado o texto em estudo?

b) Que tipo de linguagem ele apresenta?

c) Qual é o tempo verbal predominante no texto?

d) Em que pessoa predominam os verbos e pronomes? Por quê? 
Estamos diante de uma proposta de trabalho embebida do "silêncio fundante" de que trata Orlandi (2007a), ou seja, palavras que silenciam outras que poderiam representar, talvez, uma "ameaça” a alguns. Nesse sentido, ao tratar de um tema tão relevante como a formação profissional, principalmente no atual contexto brasileiro, em que o ensino superior vive momentos conflituosos que acabam por gerar greves longas, porém sem o alcance dos efeitos pretendidos, o livro didático apaga (silencia) essa situação que está quase sempre fora da ordem e privilegia, por meio de questões superficiais e fechadas, um conhecimento que não coloca o aluno na posição de um sujeito que pode questionar o reducionismo da matéria estudada, argumentar, confrontar, ou seja, na posição-sujeito que pode instaurar o discurso polêmico (ORLANDI, 2003). Sobre isso, vale ressaltar o que coloca Pacífico (2008, p.183):

\begin{abstract}
Analisando vários textos que circulam em livros didáticos diferentes, encontramos temas muito interessantes, cuja leitura e interpretação podem proporcionar aos alunos um contato e, por que não, um confronto com o contexto sócio-histórico-ideológico que os cerca. Todavia, observamos atividades de leitura e interpretação (se é que podemos considerar como interpretação) reducionistas e silenciadoras, na medida em que escamoteiam a historicidade, o interdiscurso, a exterioridade do texto por meio de perguntas ingênuas, que requerem dos alunos a cópia, a paráfrase, ou seja, o silenciamento (cf. Orlandi, 1997b) de suas possíveis interpretações.
\end{abstract}

Dessa mesma forma, o livro didático que analisamos silencia questões importantes como, por exemplo, o que significa ser um leitor da revista "Veja” em nosso país, o que representa dizer, em um país com sérios problemas na Educação Básica, que a fórmula do sucesso depende quase que exclusivamente da competência dos estudantes, quais preocupações com a formação profissional poderiam/deveriam estar à frente de uma competição como é o caso da Olimpíada do conhecimento. Em lugar disso pede-se ao aluno que ele simplesmente procure uma "frase que praticamente sintetiza a ideia principal do texto", que ele "explique porque a competição entre os melhores profissionais tem favorecido o desenvolvimento desses países”, ou seja, que ele vá reiterando a opinião já trazida pelo jornalista, sem, em momento algum, disputá-la.

Assim, o livro didático induz o sujeito-aluno a uma leitura parafrástica (ORLANDI, 2008), impondo que esse sujeito reproduza sentidos trazidos como únicos possíveis e verdadeiros. Conforme Orlandi (2008, p.43), “nesse circuito da leitura de prestígio, o professor, por sua vez, retoma, em seu trabalho pedagógico, uma leitura considerada como ideal e que tem como modelo a de um crítico” que, no caso que ora analisamos, encontra-se na figura do autor do livro didático. Esse último, através de questões “enrijecidas” sobre o texto jornalístico, “fixa- 
lhe um sentido que é considerado o desejado (o prestigiado) para a leitura” (ORLANDI, 2008, p.42).

Fica, portanto, interditado ao aluno questões pertinentes e relevantes sobre a formação profissional em nosso país, sobre as relações desiguais de poder que perpassam a temática da Educação no Brasil e, em vez disso, priorizam-se questões práticas do texto como "que tipo de linguagem ele apresenta”, “qual é o tempo verbal predominante no texto”, “em que pessoa predominam os verbos e pronomes”, etc. Pensamos, então, na ilusão de completude dos sentidos trazidos por um livro didático, que, nesse caso, deixa no sujeito a ilusão de que é necessário apenas saber dizer que mecanismos foram utilizados pelo jornalista para entender como se dá a argumentação. Ou, quem sabe, para cumprir um protocolo escolar: o aluno foi à escola, fez a lição e respondeu as perguntas do livro. Ainda nessa perspectiva de trabalho, o material didático continua com o recorte $\mathrm{D}$ : 


\section{Recorte D}

\section{1 a proposta}

Leia, inicialmente, este texto.

\section{Leitura}

\section{Pesquisa com animais deve ser desmistificada}

Diretor-associado de um centro americano diz que prática é regulada pelo governo e que é prevista em lei

Informar o público e regulamentar a pesquisa são fatores essenciais para desmistificar o uso de animais em laboratório, diz o endocrinologista Michael Conn, diretor-associado do Centro Nacional de Pesquisas com Primatas do Oregon, nos EUA. "Pesquisas com animais são rigorosamente regulamentadas", disse ao Estado, após palestra de abertura da reunião anual da Federação de Sociedades de Biologia Experimental (Fesbe), em Águas de Lindoia.

Em enquetes nos EUA, diz ele, cerca de $50 \%$ das pessoas dizem ser favoráveis ao uso de animais. Informadas de que a prática é regulamentada pelo governo federal, a aprovação sobe para $95 \%$. Nos $5 \%$ restantes, estão os chamados "extremistas", que se opõem ao uso de animais sob qualquer condição. Conn conhece bem essa minoria: o Centro Nacional de Pesquisas com Primatas do Oregon é um dos principais alvos de ataques e protestos. Conn já foi ameaçado e teve de pedir proteção policial. Viu colegas abandonarem pesquisas por conta disso. Alguns tiveram suas casas pichadas e até incendiadas.

Segundo ele, é possível que um dia o uso de animais não seja mais necessário, "mas esse dia ainda não chegou". "Em alguns casos, é possível usar culturas de células, em outros, é possível usar epidemiologia ou programas de computador. Mas, na maioria dos casos, $\mathrm{o}$ uso de animais é indispensável." Não só do ponto de vista científico, mas legal: a lei americana exige que qualquer droga, antes de ser testada em humanos, seja testada antes em pelo menos duas espécies animais. A lei também obriga os pesquisadores a tomar todas as medidas possíveis para minimizar o sofrimento dos animais. Fotos de macacos com o cérebro exposto e outras cenas de "tortura" são enganosas. "Essas fotos são usadas há 20 ou 30 anos. Ninguém sabe de onde elas vieram, nem os próprios extremistas", diz Conn.

O Brasil aprovou em 2008 uma lei que regulamenta o uso de animais em pesquisa. Até então, as regras eram definidas pelas instituições de pesquisa. Agora, essa responsabilidade caberá a um conselho federal, que está sendo montado com representantes da comunidade científica, dos ministérios e da sociedade civil. "Queremos promover uma discussão que proteja os animais e regule a pesquisa de uma forma coerente", disse Marcelo Morales, presidente da Comissão de Ética com Animais da UFRJ.

O Estado de S. Paulo, São Paulo, 21 ago. 2009. 
Realizando movimento semelhante ao das propostas anteriores, temos nos recortes D e E, retirados do mesmo livro didático, outro texto jornalístico que servirá de matéria prima para que os alunos respondam algumas questões. Vale dizer que, para nós analistas, a própria persistência do livro didático analisado em trazer o texto jornalístico seguidas vezes já indicia a legitimação deste como aquele capaz de oferecer ao aluno todo o conhecimento necessário sobre argumentação, silenciando (ORLANDI, 2007a), dessa maneira, teorias que poderiam melhor orientar esses sujeitos e colocá-los em contato com os saberes teóricos produzidos sobre e nos textos dissertativo-argumentativos. Ao mesmo tempo, esse modo de trabalho quase integral com o texto jornalístico, se acatado pelo professor, representa um risco na medida em que restringe a leitura do aluno unicamente aos sentidos produzidos pelo jornalista.

Nesse exemplo, a matéria jornalística tirada do jornal “O Estado de São Paulo” e publicada em 2009 trata de uma temática bastante polêmica, qual seja, o uso de animais para pesquisas em laboratório.

O texto, que pelo menos no livro didático não traz o nome do autor, começa marcando seu posicionamento a respeito da questão já no título "Pesquisa com animais deve ser desmistificada”. Seguido do título, temos uma espécie de subtítulo que funcionaria como um headline da notícia, ou seja, uma frase de efeito falando sobre o tema de modo a incitar o leitor para a leitura. Tal recurso é característico da notícia jornalística que, encontrando-se dentro de um suporte - nesse caso o jornal - visa atrair o maior número possível de leitores através dessas “chamadas” e, assim, fazer crescer a vendagem dessa mídia impressa.

Continuando a matéria, o jornalista recorre à citação de um especialista para validar seu posicionamento diante da questão e, para isso, inscreve-se no tempo e espaço desta “autoridade”, tentando nos fazer crer, por meio de uma “encenação” (MAINGUENEAU, 1997), que é o próprio Michael Conn quem fala em seu texto. Entendemos, assim como Fernandes (2005, p.29), que o sujeito discursivo, sendo heterogêneo, é “constituído na interação social, não é o centro de seu dizer, em sua voz, um conjunto de outras vozes, heterogêneas, se manifestam”, se inscrevem. Nesse caso, estamos falando daquilo que Authier-Revuz (2004, p.12) vai tratar como uma forma explícita (ou marcada) da heterogeneidade, ou seja, nas palavras da autora:

É o outro do discurso relatado: as formas sintáticas do discurso indireto e do discurso direto designam, de maneira unívoca, no plano da frase, um outro ato de enunciação. No discurso indireto, o locutor se comporta como tradutor: fazendo uso de suas próprias palavras, ele remete a um outro como fonte do "sentido" dos propósitos que ele relata. No discurso direto, são as próprias 
palavras do outro que ocupam o tempo - ou o espaço - claramente recortado da citação na frase; o locutor se apresenta como simples "porta-voz".

Esta heterogeneidade, que perpassa o discurso jornalístico e que aparece em sua forma marcada no início do texto jornalístico que ora analisamos, é também constitutiva e promove, a partir de uma constante busca no interdiscurso, a propagação de sentidos legitimados pela classe dominante. Devemos também lembrar, como o faz Pacífico (2008, p.184), “que os veículos de comunicação estão a serviço desta classe, fazendo circular sentidos que podem e devem ser lidos”. Assim, quando, no texto midiático que analisamos, temos que dentre os que não são favoráveis ao uso de animais “estão os chamados extremistas”, não podemos deixar passar despercebida a tentativa de naturalização (ideologia) de sentidos como: protestantes são extremistas e, portanto, perigosos, como se protestar diante de uma causa como a dos animais fosse algo extremo e rejeitável, como se pelo simples fato de ser regulamentada pelo governo, a prática de testes em animais devesse ser aceita e acatada por todos.

Pensamos, dessa maneira, em duas formas de ler esse texto midiático. Em uma delas, ingênua, o sujeito aceita prontamente os sentidos produzidos pelo jornalista e não questiona, por exemplo, o fato de ter sido usado o termo "extremista”, que resgata no interdiscurso, toda uma rede de sentidos sobre terrorismo, violência, etc. Na outra forma de leitura do texto que, como vimos pelas questões propostas, não é a sustentada na escola pelo livro didático, o sujeito poderia expor-se à opacidade do texto, ousando interpretar e duvidar dos sentidos ali naturalizados.

Nessa última concepção de leitura, encaixa-se aquele sujeito que será capaz de ocupar a função-leitor (PACÍFICO, 2002) e que mais tarde poderá argumentar sobre o que lê, colocar em disputa outros textos sobre a questão e, então, produzir novos sentidos sobre o tema. Assim, ainda em consonância com Pacífico (2002, p.48), esse sujeito poderá “explorar a possibilidade do novo, do diferente e para nós, a persuasão está ligada ao inesperado, àquilo que influencia o imaginário do interlocutor”. Portanto, entendemos que esse tipo de leitura - polissêmica - é condição para que se realize a argumentatividade.

No entanto, a maneira como esse livro didático trabalha com a matéria jornalística não permite esse tipo de leitura; logo, não permite ao sujeito-aluno o exercício da argumentação, como poderemos observar, a seguir, no recorte E: 
Recorte E

1 Qual é a tese ou o ponto de vista que está exposto no primeiro parágrafo, e que será defendido nos demais parágrafos?

2 Que argumentos Michael Conn desenvolve no segundo parágrafo, ao defender seu ponto de vista?

3 No terceiro parágrafo, o endocrinologista utiliza outros mecanismos argumentativos, desenvolvendo opiniões que se tornam ainda mais convincentes. Comente esses argumentos.

4 Explique como o autor do texto retomou a ideia inicial ou ponto de vista, no último parágrafo.

5 Releia o texto, se necessário, e explique como o autor conseguiu manter a unidade no encadeamento das ideias.

6 De que modo ele conferiu credibilidade às ideias apresentadas, com o objetivo de convencer o leitor a aceitar seu ponto de vista?

Outra vez encontramo-nos diante de um questionário que não instiga a interpretação, pelo contrário, limita-a, e ainda legitima os sentidos já produzidos pelo jornalista ao apenas perguntar para o aluno qual é a tese principal defendida por ele. Desse modo, o material didático pressupõe um leitor que deverá realizar um trabalho prático de busca pela opinião apresentada no texto, como se só isso já fosse o suficiente para que ele construísse um ponto de vista e compreendesse como argumentar em favor dele.

Na pergunta de número dois, o autor do livro didático parece ter entrado na "encenação" (MAINGUENEAU, 1997) do jornalista que, como vimos, coloca-se no tempo e espaço do especialista citado, de modo a fazer parecer que é o próprio especialista quem fala em seu texto. Assim, quando o autor desse material indaga "que argumentos Michael Conn desenvolve no segundo parágrafo ao defender seu ponto de vista?”, ele está entrando no “jogo” criado pelo jornalista e, ao mesmo tempo, autenticando a validade de seus argumentos. Continuando nesse jogo, temos ainda, na pergunta de número três, a afirmação de que “o endocrinologista utiliza outros mecanismos argumentativos”, como se o texto jornalístico tivesse sido elaborado pelo médico e não pelo jornalista.

Isto, por sua vez, somado à ingenuidade das perguntas que seguem, pode escamotear a historicidade do texto, fazendo com que o aluno fique sujeito àquilo que a mídia quer que ele 
acredite ser verdade, apagando-se, igualmente, que esse texto compõe um todo junto com a página jornalística e que esse todo também discursiviza um posicionamento da mídia que, ao contrário do que se pode pensar, não é neutra.

Passaremos agora para outra proposta trazida pelo livro que vai tratar da violência nos trotes universitários. Olhemos, então, para o recorte F:

\section{Recorte F}

\section{$2^{\mathrm{a}}$ proposta}

Nesta proposta, você vai produzir um texto dissertativo-argumentativo com quatro parágrafos. Antes, leia trechos de um texto que relata as consequências de um trote aplicado em duas calouras em uma faculdade do país.

\section{2 alunas, uma delas grávida, são queimadas em trote}

Duas calouras [...] foram internadas com queimaduras causadas por produtos químicos despejados em seus corpos durante trote na noite de segunda-feira. Ontem, passaram por exame de corpo de delito e prestaram depoimento na Delegacia da Mulher, onde foi aberto inquérito.

Por causa do ataque, as duas tiveram de ser internadas e medicadas para amenizar dores e sintọmas de intoxicação.

[...] a assessoria da fundação lamentou o incidente e informou que proibiu trotes tradicionais nos campus - mesmo assim, alunos continuaram com a recepção violenta do lado de fora. A fundação informou que vai acompanhar o inquérito para adotar medidas cabíveis.

O Estado de S. Paulo, São Paulo, 12 fev. 2009. (Fragmento).

Dessa vez o livro didático lança mão de trechos de um texto jornalístico publicado pelo jornal “O Estado de S. Paulo”, em 2009, para propor uma temática a partir da qual os alunos produzam um texto dissertativo-argumentativo. Essa temática gira em torno dos trotes violentos aplicados por universitários, porém, diferentemente dos recortes anteriores, nesse caso o que é apresentado para o aluno não é um texto argumentativo, mas trechos de uma notícia veiculada pelo jornal. 
Já no início da proposta, o autor do livro determina que o aluno "vai produzir um texto dissertativo-argumentativo” e impõe o número de parágrafos que deverá constituir esse texto, a saber, “quatro parágrafos”.

Para nós, retomando a tipologia discursiva proposta por Orlandi (2003), essa imposição do livro didático funciona como um indício daquilo que a autora nos diz sobre o discurso pedagógico, ou seja, que ele é autoritário. De acordo com Orlandi (2003, p.85):

As diferentes situações de linguagem são reguladas: não se diz o que se quer, em qualquer situação, de qualquer maneira. O discurso pedagógico não foge a essa dinâmica de tipos: tal como existe atualmente em nossa sociedade, o DP é um discurso autoritário: sua reversibilidade tende a zero (não se dá a palavra), há um agente único aquele que tem o poder de dizer), a polissemia é contida (se coloca o sentido único), o dizer recobre o ser (o referente está obscurecido).

Não obstante, o livro didático, veiculando o discurso pedagógico, incorpora esse modo de funcionamento autoritário, limitando a escrita do aluno a quatro parágrafos, como vimos, e estipulando um sentido único como poderemos melhor observar através do recorte G, logo mais, que é uma continuação dessa mesma proposta do material didático: 


\section{Recorte G}

0 tema abordado é polêmico, pois, apesar das proibições, há estudantes que ainda insistem em recepcionar os calouros com trotes violentos. Esse é somente um dos casos divulgados pela imprensa.

Siga estas orientações.

- Leia mais sobre o assunto, antes de iniciar o texto. Organize as informações relevantes, os dados e testemunhos mais exatos, sustentados na realidade dos fatos. Essa prática dá força argumentativa às ideias.

- Empregue a variedade padrão formal da língua, os verbos com predominância no presente do indicativo, e a $3^{\mathrm{a}}$ pessoa dos verbos e pronomes, para garantir a impessoalidade exigida neste tipo de texto.

- Reflita bem sobre o assunto e planeje o seu texto. Defina seu ponto de vista ou ideia principal, a ser exposta no primeiro parágrafo.

- No segundo e terceiro parágrafos, desenvolva os argumentos já esquematizados. Observe se eles estão bem embasados, ou seja, persuasivos, com ideias claras e coerentes. Empregue os elementos coesivos com adequação (preposições, conjunções, pronomes demonstrativos e relativos etc). Lembre-se de que a organização lógica e sequencial dos argumentos, assim como a coesão de palavras, frases e parágrafos caracterizam uma argumentação bem feita. Escolha vários argumentos sobre o assunto, mas todos relacionados à ideia principal, visando defender seu ponto de vista.

- Releia o texto, antes de construir o último parágrafo. Faça uma conclusão, retomando a ideia inicial apresentada no primeiro parágrafo, e apresente soluções que ajudem a resolver o problema enfocado. Não se esqueça do título.

Nesse recorte, o livro didático dá continuidade à proposta de produção textual, determinando, com o uso do imperativo, que o aluno "siga estas orientações”. Antes disso, porém, o autor do livro marca seu posicionamento diante do tema, dizendo que se trata de um “tema polêmico", ao mesmo tempo em que parece identificar-se com certa formação discursiva - a mesma do jornal - para a qual os trotes violentos são uma barbárie. Dessa maneira, embora o autor afirme existir uma polêmica no tema, ele não polemiza de fato, não chama o leitor para uma discussão mais aprofundada. Pelo contrário, ele, o autor do livro didático, justifica dizendo 
que “é polêmico, pois, apesar das proibições, há estudantes que ainda insistem” nos trotes violentos, mostrando-se, assim, desapontado com a violência relatada na notícia.

Não pretendemos aqui questionar a veracidade da notícia e muito menos defender qualquer tipo de violência; no entanto, como já marcamos, não entendemos o discurso jornalístico como neutro ou livre de “submissões” ideológicas. Ao contrário, fazendo parte de um suporte maior - o jornal em si -, ele também inscreve-se em uma formação discursiva para enunciar de uma maneira e não de outra, fazendo circular determinados sentidos e silenciando outros, não desejáveis (ORLANDI, 2007a).

É dessa mesma forma que trabalha o livro quando, apesar de dizer que o tema é polêmico, aponta para um sentido único, ou seja, espera do aluno que ele apenas reproduza/comente os dados da notícia jornalística e assuma um posicionamento contrário à violência. Apaga-se, então, o contexto em que a notícia foi publicada, seu lugar na página do jornal e, assim, o modo como esta mídia discursiviza os estudantes universitários, tenta controlar outros sentidos possíveis que perpassam a complexa problemática envolvida na questão. O livro didático silencia, dessa maneira, os tantos outros sentidos que poderiam estar em disputa com o jornal, interditando o acesso ao arquivo (PÊCHEUX, 2010) por oferecer a esse sujeito-aluno um único e pequeno amontoado de trechos da matéria jornalística. Nossa questão é: como, então, espera-se desse aluno uma argumentação persuasiva?

Cria-se, com o uso de “siga estas orientações” a ilusão de que a resposta para essa questão poderia estar nas “orientações” fornecidas pelo livro didático que, como subentendese pela própria definição no dicionário Houaiss (2001), diz respeito ao “ato ou efeito de orientarse, direcionar-se para o Oriente”, ou seja, para o lado certo, onde, nesse caso, estaria o conhecimento que permitiria ao aluno argumentar. No entanto, não apenas por estarmos filiadas à Análise de Discurso de vertente francesa e duvidarmos dos sentidos sedimentados no dicionário, mas, principalmente, porque nossas análises nos permitem observar, sabemos que tais “orientações” não respondem a nossa questão, pois, como veremos, elas apenas esquematizam o caminho que deverá ser percorrido pelo aluno em seu texto, mas não o ensina a produzir um texto argumentativo que seja persuasivo.

Temos, pois, na primeira “orientação” dada pelo livro didático, um chamado para que o aluno "leia mais sobre o assunto", sem, entretanto, fornecer a esse aluno nenhum outro texto ou indicação de leitura. Nesse sentido, o manual dá indícios de que apenas aquela leitura não basta para a produção textual do aluno e nós também entendemos, assim como Pacífico (2002, p.51), que "a escola precisa ir além do livro didático, levar para dentro de seus muros outros e novos textos”. Entretanto, sabemos que, não raras vezes, o livro didático constitui-se como um dos 
poucos recursos aos quais o professor tem acesso, o que, nesse caso, seria altamente danoso para a construção do “arquivo” (PÊCHEUX, 2010) desses sujeitos-alunos e, por consequência, impossibilitaria a assunção da autoria e a argumentação.

Seguindo com as “orientações”, o material didático vai traçando uma espécie de roteiro que deverá ser seguido para a produção do texto. De acordo com esse roteiro, o aluno deverá utilizar a variedade padrão formal da língua, empregar os verbos no presente do indicativo, expor o seu ponto de vista no primeiro parágrafo, desenvolver argumentos nos segundo e terceiro parágrafos e, finalmente, retomando a ideia principal, concluir o texto no quarto parágrafo.

Percebemos que essa receita pronta que o sujeito recebe simula uma completude na medida em que deixa, nesse aluno, a ilusão de que basta seguir as indicações para construir uma argumentação "bem feita”. Contudo, entendemos que apenas usar a norma culta padrão ou seguir uma estrutura textual não garante ao aluno escrever um bom texto. Nesse sentido, concordamos com Pacífico e Romão (2007a, p. 315) quando assinalam que:

\begin{abstract}
Não é suficiente apenas um conhecimento linguístico para que a leitura, a interpretação e a produção de texto sejam acessíveis ao sujeito, pois, em cada situação de enunciação, existem outras relações que podem ser (e são) estabelecidas entre o sujeito e o sentido, que não pertencem tão somente à ordem da língua, mas sim, reclamam a compreensão de sua exterioridade.
\end{abstract}

Mesmo assim, o livro didático parece esquecer essas relações, privilegiando o modo como se escreve e a linguagem que se usa, como se isso, por si só, bastasse para que o texto fosse argumentativo.

Outra proposta, ainda mais fechada, encontra-se no recorte $\mathrm{H}$, retirado do terceiro volume de um livro didático intitulado “Linguagem em movimento” e utilizado atualmente, no ensino médio de uma escola pública de Ribeirão Preto. Vale ressaltar que o título deste manual sugere que o sujeito terá espaço para movimentar-se nas atividades de linguagem, talvez espaços polissêmicos, percursos discursivos. Passemos, então, ao recorte e vejamos se realmente há possibilidades de movimento para o leitor: 


\section{Recorte $\mathrm{H}$}

\section{Propostas de produçãa de texta}

1. Leia os dados apresentados nas tabelas abarxo, determine o tema que engloba todas as informaçōes e redija uma dissertaçăo em quatro parágrafos, conforme as orientaçōes.

\section{Dados para o 1: parágrafo de desenvolvimento}

A AOA (Associação Americana de Obesidade) concluiu que, entre as crianças de 6 a 11 anos, 30,3\% estão com sobrepeso, sendo a metade destas realmente obesas.

No Brasil, os números também preocupam: o IBGE constatou que $35 \%$ das crianças estão acima do peso; dessas, $75 \%$ são obesas.

A quantidade de obesos entre 6 e 15 anos triplicou entre 1990 e 2001 e passou de $5 \%$ para $16 \%$.

Complicaçōes associadas ao excesso de peso, como hipertensão arterial, diabetes tipo 2 e altas doses de gorduras no sangue, antes eram consideradas problemas de adulto, mas hoje se sabe que atingem crescentemente o universo infantil.

Uma criança obesa tem $50 \%$ a mais de chance de se tornar um adulto obeso, desenvolvendo doenças como diabetes, derrames e infartos.
Dados para o 2: parágrafo de desenvolvimento

Nos EUA, a Kraft, grande empresa multinacional produtora de alimentos, pretende deixar de veicular propagandas de gêneros alimentícios com baixo valor nutritivo ou altamente calóricos em publicações ou programas voltados para crianças de até 11 anos.

O grupo McDonald's de fast food tem procurado atender aos clientes que buscam uma dieta mais saudável: incorporou saladas, frutas e água de coco a seu cardápio.

O governo do Estado do Rio de Janeiro proibiu a venda e a propaganda de alimentos e bebidas que colaborem para a obesidade infantil nas escolas públicas e particulares.

Fonte: Folha Online http://www.folha.uol.com.br/

\section{Orientações}

\begin{tabular}{|c|c|}
\hline Introdução & $\begin{array}{l}\text { Apresentação do tema. } \\
\text { Tese: exposiçăo de uma opiniăo sobre o tema. }\end{array}$ \\
\hline $\begin{array}{l}\text { 1: parágrafo de } \\
\text { desenvolvimento }\end{array}$ & $\begin{array}{l}\text { Mostrar o crescimento da obesidade entre jovens e alertar para os } \\
\text { riscos do problema (usar dados da tabela acima). }\end{array}$ \\
\hline $\begin{array}{l}\text { 2: parágrafo de } \\
\text { desenvolvimento }\end{array}$ & $\begin{array}{l}\text { Mostrar que já existem medidas que procuram solucionar o } \\
\text { problema (usar dados da tabela acima). }\end{array}$ \\
\hline Conclusão & Retomar a ideia da tese. \\
\hline \multicolumn{2}{|l|}{ Observações } \\
\hline \multicolumn{2}{|c|}{ Năo é preciso empregar em seu texto todos os dados fornecidos. } \\
\hline \multicolumn{2}{|c|}{$\begin{array}{l}\text { - É interessante pesquisar outros dados e exemplos, de modo que seu texto se diferencie dos demais } \\
\text { e apresente uma marca mais pessoal. }\end{array}$} \\
\hline \multicolumn{2}{|c|}{$\begin{array}{l}\text { - Evite copiar as frases tal como são apresentadas: compreenda as informações e apresente-as da } \\
\text { maneira que lhe parecer mais conveniente. }\end{array}$} \\
\hline \multicolumn{2}{|c|}{$\begin{array}{l}\text { - Evite colocar todos os dados num mesmo período. Divida cada parágrafo em mais de um período, } \\
\text { para facilitar a leitura e compreensăo do texto. }\end{array}$} \\
\hline
\end{tabular}

Assim como no recorte anterior, temos uma proposta "engessada” de produção textual, também sustentada nas “orientações” que impõem o número de parágrafos a serem desenvolvidos “conforme as orientações”. Notamos, então, que, mais uma vez, faz-se presente o discurso autoritário, ou seja, aquele que, segundo Pacífico (2002, p.49), "não permite a 
discussão, a disputa pelo objeto discursivo, pois os argumentos arrolados são impostos de cima para baixo, numa estrutura hierárquica”, o que faz com que o sujeito não argumente, mas seja argumentado.

Também nesse livro temos o discurso midiático delineando a temática sobre a qual o aluno deve escrever. Dessa vez, o discurso jornalístico aparece na forma de uma tabela, na qual se encontra uma série de trechos retirados da versão online do jornal "Folha de S. Paulo" e que, segundo o livro didático, deverão servir como argumentos para as produções dos alunos.

Continuando com a proposta, após terem sido determinados quais dados deveriam ser usados em cada um dos parágrafos de desenvolvimento, o livro didático apresenta as “orientações” para a elaboração do texto que, nada mais são do que um resumo esquemático falando do que deverá conter cada parágrafo. Mais uma vez, então, temos uma atividade que é imposta ao aluno pelo material, sem nenhuma explicação de seu porquê, como se esse aluno não precisasse ser informado a respeito dos "propósitos de cada atividade ou de cada texto incluído no livro didático” (GRIGOLETTO, 1999, p.69). Ainda de acordo com Grigoletto (1999, p.69), “essa estrutura cristalizada do livro didático que, já o dissemos, contribui para corroborá-lo como um discurso de verdade, revela seu caráter massificante, ao negar espaço para a individualidade do aluno, abafando a expressão da voz de cada um”.

Além disso, esse esquema com moldes pré-estabelecidos, em que se pretende um raciocínio lógico, coerente acompanhado de uma linguagem “clara”, pressupõe um "sujeito descentrado, planejador do seu próprio dizer” (TFOUNI, 1995, p.82). Entretanto, como sabemos a partir da Análise de Discurso, nem a língua é clara (transparente) e nem o sujeito tem domínio sobre o seu dizer, pois “o que é dito em outro lugar também significa nas ‘nossas’ palavras” (ORLANDI, 2007b, p.32) e é esta constituição do discurso que irá determinar suas formulações, nesse caso, as formulações dos sujeitos-alunos ao produzirem seus textos argumentativos. Conforme vimos, pelas análises, apesar de o título sugerir movimento, o que encontramos foi uma fôrma (PACÍFICO, 2002) que tenta moldar os alunos no que seria um texto argumentativo, sem deixar que eles se movimentem para ocupar o lugar de quem pode argumentar. Voltemos o olhar, agora, para outro recorte, denominado recorte I: 


\section{Recorte I \\ texto \\ argumentativo}

\section{TRABALHANDO O GÊNERO}

Ao informar os fatos à população, os jornais procuram noticiar de forma imparcial e objetiva, isto é, sem manifestar nas notícias sua opinião. Para as opiniões - tanto as do próprio jornal quanto as do leitor - existem seções específicas, como o editorial e as cartas dos leitores.

O editorial, por veicular opiniões do jornal, caracteriza-se como um texto de natureza argumentativa.

Leia o editorial a seguir e responda às questões propostas.

\section{Juventude ameaçada}

O crescimento da aids, o aumento da criminalidade e a escalada das drogas representam grave ameaça à juventude no limiar do novo milênio. O diagnóstico, sombrio, consta de recente relatório preparado pela Organização Mundial da Saúde (OMS).

Para muitos jovens, "especialmente os que crescem em zonas urbanas pobres, os anos da adolescência serão os mais perigosos da vida", sublinha o documento. Segundo o texto da OMS, o crescimento da aids pode comprometer os progressos na área da saúde infanto-juvenil feitos nas últimas décadas.

Gravidez precoce, aborto, doenças sexualmente transmissíveis, aids e drogas compõem a trágica equação que ameaça destruir o sonho brasileiro.

Dados do Sistema Único de Saúde (SUS) indicam que $54 \%$ das adolescentes sem escolaridade já ficaram grávidas. Os casos de aids em

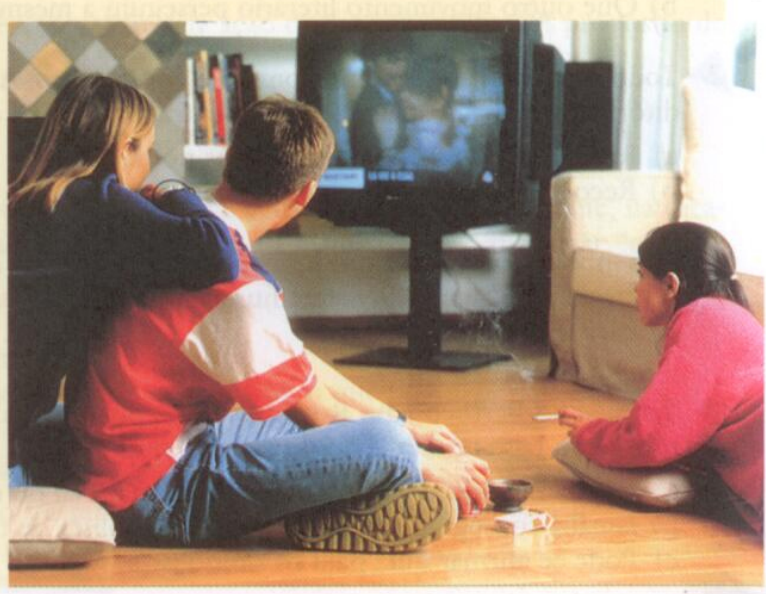

(O Estado de S. Paulo, 27/5/1998.)

Neste recorte, retirado de um capítulo de outro livro didático, “Português: linguagens”, que trata da produção de textos do gênero argumentativo, temos um editorial do jornal " $\mathrm{O}$ Estado de S. Paulo”, servindo de exemplo e de molde para que, posteriormente, o aluno também possa escrever o seu texto argumentativo.

A esse respeito, concordamos com Pacífico (2002, p.55) quando a mesma questiona o trabalho com o texto argumentativo na escola e diz que:

Se a escola espera que o sujeito escreva sobre algo de forma argumentativa e, como já vimos, para argumentar o sujeito precisa ter um ponto de vista formado e um certo conhecimento sobre o objeto discursivo, como é que o mesmo sujeito pode construir "seu” ponto de vista sobre um objeto se ele não tem 
acesso ao arquivo, se a escola (ensino fundamental e médio) não lhe dá meios para realizar pesquisas, para investigar os discursos acordes e discordes sobre determinado tema? Ao contrário, a escola trabalha com a concepção de sujeito universal e mostra, para este, uma visão dada como certa e inquestionável e aguarda a homogeneização dos textos produzidos pelos alunos, textos que devem repetir os “argumentos” dados por alguma "autoridade” no assunto.

Isso também ocorre no recorte que estamos analisando, pois, como podemos observar, ao invés de a escola oferecer vários textos sobre o tema ao aluno e de promover o debate, a “disputa pelo objeto discursivo” (PACÍFICO, 2002), ela, ao contrário, legitima um discurso midiático sobre o tema, conferindo-lhe uma “autoridade” que, muitas vezes, é corroborada pelo professor ao exigir de seus alunos a paráfrase, ou seja, a repetição dos sentidos trazidos por esse discurso.

Outro equívoco pode estar nas próprias concepções trazidas pelo livro didático. Esse último, muitas vezes, ao buscar "ensinar” o aluno a escrever, apresenta textos que restringem o conhecimento desses sujeitos, ao mesmo tempo em que simulam trazer tudo sobre aquele assunto. Para explicar a questão, olhemos para o seguinte recorte, chamado recorte J, retirado do mesmo livro didático:

\section{Recorte J}

A INFORMATIVIDADE NO DISCURSO

Toda produção de texto, oral ou escrito, deve levar em conta os componentes básicos que participam das situações discursivas em geral: quem fala, para quem fala, com que intenção e, mediante esses elementos, como fala. Neste componiente, o "como falar", tem papel fundamental a informatividade.

$\mathrm{O}$ sucesso de qualquer interação comunicativa depende diretamente da adequação do grau de informatividade do texto ao repertório cultural e lingüístico do interlocutor.

Se o interlocutor tem um amplo repertório, a expectativa é de que o discurso apresente um alto grau de informatividade. Se, entretanto, seu repertório é limitado, a informatividade deve ser necessariamente baixa, sob risco de não haver sucesso na interação verbal. 
Diferentemente do recorte anterior, esse texto não apresenta um discurso jornalístico, mas sim, uma ideia concebida pelos autores do livro sobre como deve ser a produção de um texto dissertativo-argumentativo, representando um modelo de texto informativo.

Nesse caso em particular, o que se propõe analisar não é a tessitura do texto apresentado como modelo, mas a proposta de trabalho que o livro sugere como válida quando se quer escrever um texto dissertativo que apresente uma argumentação que ultrapasse o senso comum.

Nesse sentido, o texto privilegia a forma, o “como falar”, ou seja, ele sugere que a linguagem utilizada na produção de uma dissertação argumentativa é o fator de maior relevância para seu "sucesso”, como se "falar e escrever bem” dependesse apenas da vontade do aluno para construir um bom texto, isto é, o professor ou o livro didático dão a dica e pronto! Por outro lado, sabemos que o poder argumentar está relacionado ao lugar social e discursivo que o sujeito ocupa ou pode ocupar, não se restringe a uma questão linguística (PACÍFICO, 2002), que pode ser ensinada em uma aula.

Assim posto, o livro didático delega aos alunos a responsabilidade por sua escrita e associa o "sucesso" da mesma ao "grau de informatividade" usado pelo aluno. Voltemos o olhar para o manual e verifiquemos, então, no recorte $\mathrm{K}$, constituído por duas transcrições do mesmo livro didático, o que este último traz como "grau de informatividade no discurso":

\section{Recorte K}

“A maior parte dos textos publicados em jornais e revistas apresente um grau de informatividade médio, capaz de, ao mesmo tempo, mobilizar o repertório cultural do leitor e oferecer-lhe novas informações.”

“Nos exames e concursos em que se solicita a produção de um texto escrito, como o exame vestibular, também convém trabalhar com um grau de informatividade médio.”

O que nos causa estranhamento, neste recorte $\mathrm{K}$, é o fato de que silencia a relação de poder que perpassa a escrita, como se todos os alunos que lessem o recorte e refletissem sobre “o grau de informatividade” estivessem autorizados a escrever um bom texto argumentativo. Dessa forma, ao apagar sentidos que não devem circular nos livros didáticos, pois colocariam em disputa a relação desigual que a própria escola proporciona, o manual faz parecer "natural”, pelo efeito da ideologia, que basta uma explicação para que o aluno possa argumentar. 
Entretanto, Pacífico (2002) marca que a argumentação exige a disputa do objeto discursivo, exige do aluno o acesso ao "arquivo” (PÊCHEUX, 2010); logo, não se restringe a observar o grau de informatividade do discurso.

Do que pudemos analisar até o momento, percebemos que o discurso jornalístico se faz presente na escola, disputando lugar com a teoria da argumentação e fazendo-se valer como modelo para as produções textuais dos estudantes. Apontamos também que outros discursos poderiam circular na escola, por meio do livro didático, para que os alunos pudessem observar como se constrói o texto argumentativo e, nesse próximo recorte, retirado do terceiro volume do livro "Português: ser protagonista”, daremos um exemplo disso, apresentando uma proposta que, diferentemente das demais analisadas, não faz uso do texto jornalístico e sim de redações de vestibulares produzidas em provas passadas. Observemos uma dessas redações no recorte L: 


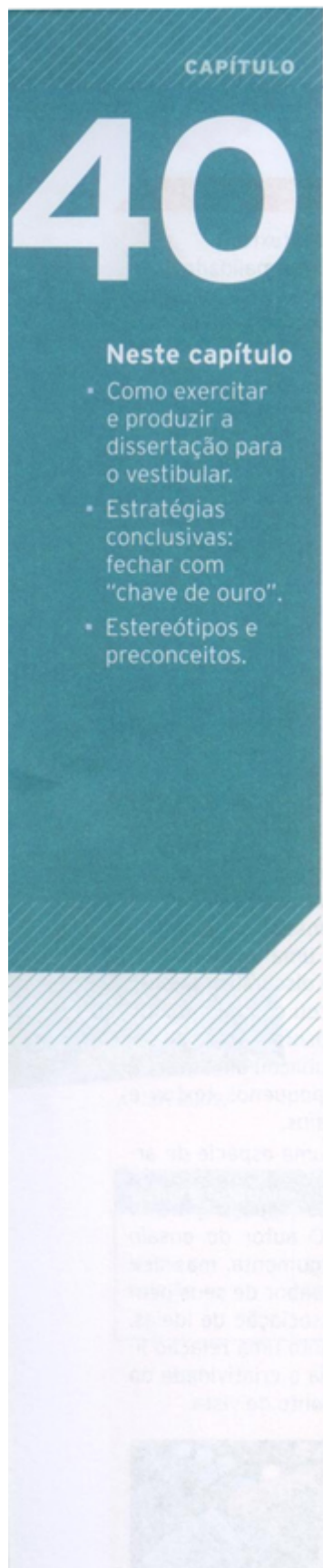

\section{Dissertação para o Enem e para o vestibular}

Para escrever um dissertação bem-sucedida no vestibular e no Enem, dominar as técnicas argumentativas ajuda, mas não é tudo. O texto também revela ao examinador o estágio da formação escolar e extraescolar do estudante. Que conhecimentos ele articula em sua argumentação? Que autonomia do pensamento o texto revela? Depois de conhecer melhor a dissertação para o vestibular, será a sua vez de se exercitar e produzir os textos.

\section{Leitura}

- Os textos abaixo foram publicados no site da Fuvest (o vestibular da Universidade de São Paulo) entre as 44 melhores redações de 2009. Leia-os com atenção e responda às questões propostas.

OBS.: Os textos foram transcritos de acordo com o original, apenas com correções ortográficas pontuais.

\section{Romper fronteiras, romper valores}

Fronteiras são limites e o homem busca ultrapassá-las. Um grande canto à quebra de fronteiras está presente em Os Lusíadas. Camões, ao narrar a viagem de Vasco da Gama às índias conta uma história não só de ultrapassagem de barreiras físicas e geográficas mas também da quebra dos limites psicológicos do povo português. Vencer fronteiras existentes ao redor do homem, leva-o a quebrar fronteiras dentro de si mesmo.

A transformação ideológica vivida pela humanidade após a Expansão Marítima Comercial, mostrada nos versos do autor português, mudou o rumo da História. Ao passar pela linha do horizonte sem cair em um abismo, como acreditava-se na época, o homem descobriu ser capaz de realizar grandes feitos sem a necessidade da ordenança divina, apenas por sua vontade. As fronteiras do Oceano foram rompidas e ajudaram na quebra do Teocentrismo.

O pensamento antropocêntrico consolidou-se. A ciência e a tecnologia evoluiram. Limites foram rompidos pela humanidade ao longo da História. A chegada do homem à Lua instigou ainda mais o sentimento de superioridade humana. O homem porém tem esquecido da fronteira que o próprio homem carrega e o limite a que pode chegar.

Fabiano em Vidas Secas, também passa por um processo de transformação interna. Por não conseguir vencer os limites da linguagem e do conhecimento, tem que romper com a fronteira entre o ser humano e o animal, transformando-se em um bicho para se adaptar às condiçōes da seca.

No mundo moderno existem diversos Fabianos. Latino-americanos que cruzam fronteiras de paises e necessitam submeter-se a condiçōes inumanas para sobreviver. Favelas crescentes e aumento da desigualdade com pessoas lutando para ultrapassar os limites da sobrevivência.

A capacidade de superação humana e quebra de barreiras é indiscutivel. Cabe ao ser humano do século XXI romper as fronteiras do individualismo para que năo mais pessoas rompam as barreiras do humano para sobreviver como animais.

Fuves 2009: exemplo 11. Disponivel em: <http://wwww fuves. br/vest2009/hestred/520866.jpg . Acesso em: 31 ago. 2009.

No recorte acima, temos também marcada o que vimos em outros livros didáticos, a saber, a preocupação com o exame vestibular. Tanto assim que o próprio título do capítulo do livro didático traz os dizeres: "Dissertação para o Enem e para o vestibular”, indicando que o conteúdo a ser tratado terá por finalidade o bom desempenho nessas provas. Porém, diferenciando-se dos demais recortes, vemos que a leitura sugerida por esse livro didático é mais coerente com sua proposta, já que apresenta não um texto jornalístico, mas uma produção 
textual bem avaliada em um dos vestibulares mais concorridos do estado de São Paulo, qual seja, a Fuvest.

Ao primeiro olhar, já é possível observarmos que o texto "Romper fronteiras, romper valores”, apresentado no recorte, parece não obedecer, em sua organização, às “orientações” que vimos acima, ou seja, ele não é rigidamente estruturado de acordo com o tão conhecido e difundido modelo de quatro parágrafos, sendo o primeiro introdutório, o segundo e o terceiro para o desenvolvimento e o quarto conclusivo. Diferentemente, ele adota um arranjo harmônico, com parágrafos não tão extensos e que dialogam perfeitamente entre si. Assim, a ideia principal do texto, que reforça a importância do homem vencer barreiras tanto externas quando as que carrega em si, parece permear toda a tessitura textual.

Percebemos ainda que, contando com uma linguagem que se diferencia em muitos aspectos daquela que vimos ser utilizada em alguns textos jornalísticos, essa redação mobiliza uma série de conhecimentos históricos e literários, criando, por sua vez, um efeito leitor diferente daquele gerado por um discurso midiático. Logo, nessa produção textual, percebemos que o vestibulando não pretende criar nenhum efeito de proximidade com o leitor - como notamos em recortes anteriores -, mas tão-somente convencê-lo, através de argumentos pautados tanto em saberes que podemos chamar de "escolares" quanto em conhecimento de mundo.

Nesse sentido, podemos dizer que esse vestibulando instala em seu texto o discurso polêmico que é também “aquele em que melhor se observa o jogo entre paráfrase e a polissemia, entre o mesmo e o diferente” (ORLANDI, 2003, p.155). Pensamos aqui que foi preciso o interdiscurso e o arquivo (PÊCHEUX, 2010), para que o candidato do vestibular buscasse no já-dito o novo, o diferente, e, desse modo, instaurasse novos sentidos sobre o tema fronteira.

Voltando ao livro didático, destacamos que, além de não utilizar o discurso midiático como modelo para a produção do texto argumentativo, esse material demonstra uma certa preocupação em apresentar ao menos alguns apontamentos sobre uma teoria da argumentação, como pode-se ver pelo recorte $\mathrm{M}$, a seguir: 


\section{Recorte M}

\section{" Conclusão: "fechar com chave de ouro"}

Quando um texto, um filme, uma obra de arte ou um pensamento convencem seu leitor ou espectador, deixando uma impressão agradável e favorável em relação à obra, diz-se que "fechou com chave de ouro".

$\mathrm{Na}$ dissertação para o vestibular, em primeiro lugar é preciso fechar a argumentação. O texto da conclusão pode resumir o raciocínio ou retomar a tese expressa na introdução ou título. Se a argumentação for bem-sucedida e estiver bem encadeada, levará naturalmente à conclusão. Mas há ainda o fechamento do texto. Numa dissertação ele costuma coincidir com o fecho da argumentação, mas pode aparecer depois, como uma frase de efeito ou um pensamento instigante. Alguma citação conhecida, um provérbio, uma proposta de solução ao problema analisado ou uma generalização da questão podem intensificar o efeito produzido pela argumentação no leitor.

Esse efeito suplementar na conclusão pode ser responsável por fechar com chave de ouro uma dișsertação para o vestibular.

1. Qual dos quatro textos, em sua opinião, "fechou com chave de ouro"? Justifique sua resposta.

2. Agora exercite a conclusão:

a) Escreva um silogismo sobre o tema "Fronteira" da Fuvest 2009 que expresse a sua opinião.

premissa maior premissa menor conclusão

b) Use o silogismo como um resumo da argumentação na conclusão do seu texto. Acrescente alguma(s) das estratégias de conclusão sugeridas nesta seção.

c) Agora escreva, se quiser, o texto todo. Revise a conclusão original e amplie ainda mais os seus efeitos.

\section{Lembre-se}

A construção do raciocínio no silogismo é demonstrada no exemplo clássico de Aristóteles:

premissa maior [afirmação universal]

Todo homem é mortal.

premissa menor [afirmação particular]

Sócrates é homem.

conclusão [afirmação necessária]

Logo, Sócrates é mortal.

Percebemos, então, a presença de alguns traços de uma teoria sobre a argumentação e, embora saibamos que apenas o que consta no livro não é suficiente, consideramos essa parte dedicada ao estudo do texto argumentativo de extrema importância e, porque não dizer, um ponto de partida para que o professor busque ainda mais textos e aprimore seus conhecimentos e o conhecimento de seus alunos. Dessa maneira, entendemos que nada pode substituir um contato do sujeito-aluno com o saber teórico sobre o argumentar, para que, a partir disso, ele possa ocupar a posição-sujeito de quem, assumindo-se autor, forma uma opinião e argumenta em favor dela, sabendo como o fazer.

Todavia, como pudemos notar, ainda encontramos em muitos livros didáticos uma predominância do discurso jornalístico, seguido por propostas de leitura ingênuas e silenciadoras (ORLANDI, 2007a) que, além de interditarem a interpretação, impossibilitam o acesso do sujeito-aluno aos tantos conhecimentos já elaborados sobre a questão da linguagem, inclusive sobre a argumentação.

Agravando tal situação, temos que considerar o que afirma Coracini (2003, p.329), depois de uma pesquisa realizada em escolas estaduais:

Os programas escolares estão sempre e inevitavelmente atrasados com relação à ciência. Fica fácil compreender o que acaba de ser exposto, se atentarmos 
para a sala de aula de língua materna nas escolas estaduais observadas em nosso projeto, onde praticamente ainda não chegaram os efeitos da lingüística do texto e, menos ainda, da análise do discurso.

Mediante nosso estudo e também baseadas em nossa experiência na escola, concordamos com Coracini (2003), pois vemos circular na mesma, por meio do livro didático, propostas de produção textual baseadas em modelos obsoletos e que não levam em conta todos os estudos que vêm sendo realizados sobre a questão da linguagem. Além disso, tais propostas, como vimos, exigem do aluno que determinados sentidos sejam reiterados, o que não raramente acontece com os sentidos trazidos pela mídia. Assim, nossas análises nos permitem afirmar que, cada vez mais a escola vem desempenhando a função de propagadora do discurso jornalístico em detrimento das teorias sobre o argumentar. Ao mesmo tempo, o livro didático, por aparentar uma “completude”, faz com que os sujeitos permaneçam ainda mais afastados dos conhecimentos sobre a argumentação.

Analisamos neste capítulo, quatro livros didáticos de diferentes coleções e observamos que, em três desses livros, o trabalho com a argumentação, o funcionamento discursivo mantêm-se o mesmo, isto é, apresenta-se o capítulo que vai tratar deste conteúdo, cuja proposta de ensino sustenta-se nas já vistas “orientações”, que, a nosso ver, constituem-se num receituário, num passo a passo que o aluno deve seguir para conseguir produzir o seu texto argumentativo. Feito isso, os livros trazem como exemplo de textos argumentativos, o discurso jornalístico. Para encerrar as atividades nas seções sobre o texto argumentativo, o material traz algumas questões que o aluno deve responder com base no texto jornalístico lido. Após essas etapas, espera-se que o aluno esteja apto para produzir sua própria argumentação. Parece simples, mas por que, então, argumentar é difícil para tantos, inclusive para alunos universitários (PACÍFICO, 2002)?

Dialogando com Aristóteles (2011), podemos compreender melhor os dados encontrados em nosso corpus. Entendemos que para argumentar o sujeito precisa persuadir seu interlocutor, fazê-lo crer, por meio de mecanismos linguísticos coerentes, que os sentidos que produz devem ser considerados, que seu ponto de vista é válido. Conforme vimos, para o autor (op. cit.), as opiniões fundamentam a persuasão e as estratégias persuasivas não podem ser as mesmas para todos os locutores, em todas as situações, pois se o auditório muda, a relação dos interlocutores, inclusive as paixões, mudam também. Com base na teoria aristotélica, podemos dizer que as propostas de ensino do texto dissertativo-argumentativo presentes nos livros didáticos analisados não constroem condições para que os alunos formem suas opiniões, considerem o interlocutor, que não deve ser somente o professor; que trabalhe as paixões 
possíveis de conquistarem determinado auditório e convencê-lo das formulações linguísticas que são construídas, seja para defender, seja para contestar dado tema.

Das “orientações” apresentadas nos livros didáticos, as que podem ser pensadas a partir de Aristóteles para o ensino da argumentação/persuasão, restringem-se à organização das partes do discurso. Para o autor, “a excelência do estilo consiste na clareza deste” (ARISTÓTELES, 2011, p. 214), Como não poderia deixar de ser, já que a escola privilegia a chamada língua culta ou padrão, a clareza e o estilo fazem parte das lições sobre como argumentar. Porém, como estamos defendendo, ao longo deste trabalho, o bom uso da língua não garante ao sujeito-aluno ocupar o lugar daqueles que podem argumentar. Ensinar argumentar reclama pensar nas condições de produção que envolvem os interlocutores, o contexto imediato, o contexto sóciohistórico, a luta de classes, quais sentidos podem e devem circular: quem pode dizer o quê? Para quem? A partir de qual lugar?

Aristóteles escreveu três livros para construir sua teoria sobre a retórica. Não temos a ilusão de defender que todas as teorias circulem, na íntegra, nas páginas dos livros didáticos, mas reduzir o ensino da argumentação a textos jornalísticos que são apresentados como exemplo e como receita a ser seguida constitui uma interdição para o aluno ao poder de argumentar. 


\section{CAPÍTULO V}

\section{O texto dissertativo-argumentativo na escola: o sujeito argumentado}

Escolhe teu diálogo

tua melhor palavra

ou

teu melhor silêncio

Mesmo no silêncio e com o silêncio

dialogamos.

(Carlos Drummond Andrade - O constante diálogo)

A partir das análises feitas no capítulo anterior, vimos o livro didático de língua portuguesa funcionando como uma voz de autoridade que, por meio de propostas de produção de texto rigidamente estruturadas, beira a imposição quando determina, "passo a passo”, como o aluno deve escrever seu texto argumentativo. No entanto, o livro didático propõe o trabalho de escrita sem oferecer ao aluno subsídios teóricos que lhe permita, de fato, compreender os mecanismos que sustentam a argumentação e como, a partir dessa teoria, produzir seu texto. Sobre isso, vale trazer as considerações de Campos (2011, p.227):

\footnotetext{
Ao propor as atividades para o aluno, introduz outro gênero do discurso "Redação de vestibular". Sem estudo sistemático desse gênero, coloca-se como pressuposto que a linguagem é transparente e abstrata, portanto, basta pedir ao aluno para praticar a escrita de redações para vestibular, sem analisar suas exigências e etapas de produção, que ele será capaz de organizar linguística e discursivamente um texto argumentativo a partir do que foi solicitado.
}

Fazendo parte de toda a problemática aqui delineada, vimos ainda, nas análises do capítulo anterior, a propagação do discurso jornalístico. Esse, por sua vez, representando outra voz de verdade dentro do livro didático, ocupa, muitas vezes, o lugar das teorias sobre a argumentação, servindo, ele mesmo, como única referência ao modo como se deve escrever de maneira argumentativa, o que, por sua vez, afasta ainda mais os sujeitos-alunos desse conhecimento. 
Por essas razões e a fim de investigarmos quais as implicações disso para os alunos, daremos início, aqui, às análises de textos argumentativos produzidos por esses sujeitos-alunos a partir de uma das propostas que vimos circular em um dos livros didáticos analisados.

Cabe destacar que, como já dissemos no capítulo que trata dos dispositivos metodológicos, não buscamos, em nossas análises, a “exaustividade horizontal” (ORLANDI, 2007b), ou seja, não entendemos que seria preciso uma vastidão de recortes para que pudéssemos “concluir” algo. Pelo contrário, além de não acreditarmos que haja essa possibilidade de conclusão, sabemos, pela Análise de Discurso, que não estamos analisando discursos fechados, mas sim, processos discursivos.

Outro ponto que merece destaque diz respeito ao próprio trabalho com a Análise de Discurso. Nesse sentido, sabemos que esse trabalho envolve sempre uma dificuldade relacionada ao fato de que o analista não tem diretamente diante de si o objeto de sua análise, qual seja, o discurso. Antes, a materialidade da qual parte o analista é o texto, o qual, remetido a um discurso, possibilita que se investiguem quais são as formações discursivas em questão, quais os sentidos derivados do jogo entre as formações ideológicas e as posições discursivas assumidas pelos sujeitos. É por esse motivo que na Análise de Discurso, a teoria deve sempre permear as análises, possibilitando ao analista desenvolver um "dispositivo de interpretação" (ORLANDI, 2007b, p.59) através do qual, diante da materialidade textual, o analista não objetive a busca por um sentido único e/ou verdadeiro, mas trabalhe justamente com a “opacidade do texto” (ORLANDI, 1996, p.64). Vale destacar o que diz Orlandi (2007b, p.60) sobre esse dispositivo:

O dispositivo, a escuta discursiva, deve explicitar os gestos de interpretação que se ligam aos processos de identificação dos sujeitos, suas filiações de sentidos: descrever a relação do sujeito com a memória. Nessa empreitada, descrição e interpretação se interrelacionam. E é também tarefa do analista distingui-las em seu propósito de compreensão.

Foi, pois, dessa maneira que buscamos trabalhar nas análises que seguirão, tendo à mão esse dispositivo que, segundo Orlandi (2007b), tem como característica colocar o dito em relação ao não dito, ou seja, possibilita que analisemos, naquilo que está dito em um texto, o que não está explícito, mas que concorre igualmente para a construção dos sentidos ali presentes. Valemo-nos, para tanto, do “paradigma indiciário” de Ginzburg (1980), que nos permite analisar, por meio de marcas linguísticas ou “indícios” presentes na tessitura do discurso, como se dá o funcionamento dos textos argumentativos dos sujeitos-alunos. 
Refletiremos também, ao longo desse capítulo, sobre os efeitos daquilo que pudemos observar na primeira parte de nossas análises, ou seja, sobre como o silenciamento da teoria da argumentação e o uso do discurso jornalístico podem afetar a escrita desses sujeitos-alunos, uma vez que, como já vimos, é papel da escola fazer com que esses sujeitos entrem em contato com os conhecimentos sobre a escrita, formando-os na posição de leitores e escritores.

Passemos, então, às análises, tomando como ponto de partida uma proposta de produção textual trazida pelo livro didático "Linguagem em movimento", utilizado no terceiro ano do Ensino Médio de uma escola pública de Ribeirão Preto. Diferentemente do capítulo anterior, aqui os recortes serão nomeados numericamente. Temos, assim, o recorte 1: 


\section{Recorte 1}
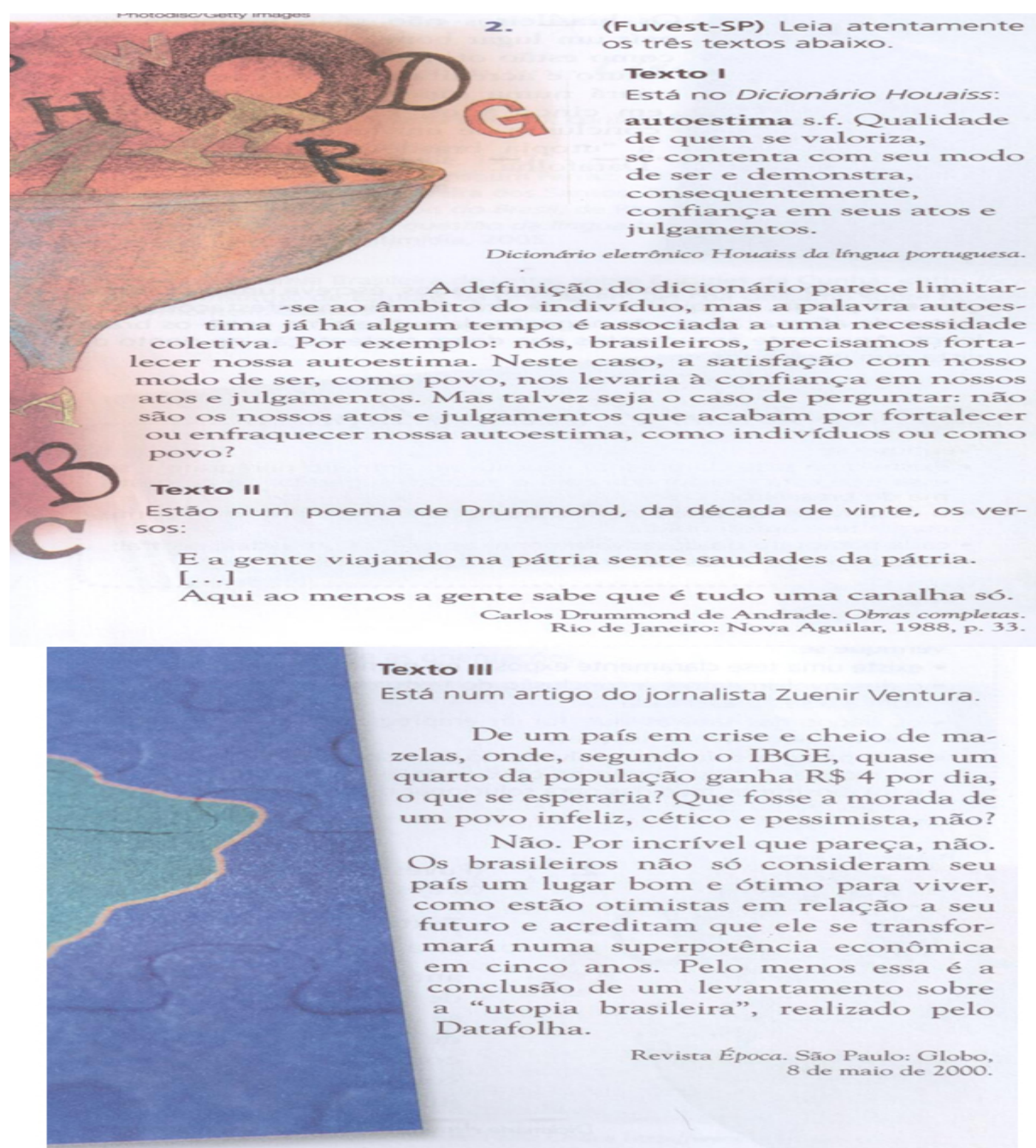

Está num artigo do jornalista Zuenir Ventura.

De um país em crise e cheio de mazelas, onde, segundo o IBGE, quase um quarto da população ganha $R \$ 4$ por dia, o que se esperaria? Que fosse a morada de um povo infeliz, cetico e pessimista, não? Não. Por incrível que pareca, não. Os brasileiros não só consideram seu país um lugar bom e otimo para viver, como estão otimistas em relação a seu futuro e acreditam que ele se transformará numa superpotência econômica em cinco anos. Pelo menos essa é a conclusão de um levantamento sobre a "utopia brasileira", realizado pelo Datafollaa.

Revista Epoca. Såo Paulo: Globo,

Com o apoio dos tres textos apresentados, escreva uma dissertação em prosa, na qual você deverá discutir manifestaçōes concretas de afirmação ou de negação da autoestima entre os brasileiros. Apresente argumentos que deem sustentaçáo ao ponto de vista que voce adotou.

Nesse recorte, temos uma proposta de produção textual que é, na verdade, uma cópia da prova de redação da Fuvest, realizada no ano de 2003. Nela, é apresentada uma coletânea de três pequenos textos que tratam da questão da autoestima relacionada, nesse caso, ao fato de o indivíduo ser brasileiro e estar (ou não) satisfeito com essa condição.

Concordamos que seja pertinente apresentar aos alunos modelos das provas vestibulares as quais esses sujeitos poderão, futuramente, ser submetidos. Todavia, percebemos em nossas análises, que o livro didático, esquivando-se de trabalhar previamente com a teoria da 
argumentação, usa essas propostas de redação não apenas como “exercícios”, mas como próprio meio de ensinar o aluno a escrever um texto argumentativo, não diferenciando, assim, a atividade de ensino da atividade avaliativa e restringindo, portanto, o conhecimento desse sujeito-educando.

Sabemos que a proposta da Fuvest, justamente por tratar-se de uma prova, tem como objetivo avaliar o repertório trazido pelo candidato bem como o modo como ele articula seus conhecimentos para argumentar em favor de um ponto de vista. Por isso, os textos de sua coletânea são curtos e buscam apenas delinear uma temática. Razão pela qual não se pode esperar de um aluno que tenha lido apenas alguns comentários genéricos sobre a argumentação e os breves textos da proposta de redação que ele já saiba, com isso, definir a temática e construir um bom texto dissertativo-argumentativo.

Voltando nosso olhar para a coletânea, vemos que o primeiro texto consiste em uma definição do dicionário "Houaiss” acerca do termo “autoestima”, contando também com um breve comentário, provavelmente, feito pelo elaborador da prova. Já o segundo texto apresenta um excerto do poema "Explicação", de Carlos Drummond de Andrade e, finalizando a coletânea, temos, como terceiro texto, o trecho de um artigo jornalístico publicado na revista “Época”, em Maio de 2000, tratando da elevada autoestima brasileira mesmo diante da crise enfrentada pelo país.

Como dissemos, os textos que compõem a coletânea da proposta de redação da Fuvest não são suficientes para que o aluno forme uma opinião, até porque, não possibilitam o acesso a um “campo de documentos pertinentes” (PÊCHEUX, 2010) sobre a questão posta e, por consequência, não assegurarão que a argumentação do sujeito-aluno tenha sustentação.

Assim, temos também, através da Análise de Discurso pechetiana, uma importante discussão sobre os riscos trazidos pela interdição do acesso ao “arquivo”, pois para interpretar - e o sujeito interpreta enquanto lê, escreve e fala - ele deve assumir o que Pacífico (2002) chama de "função-leitor", ou seja, posição assumida pelo sujeito que reflete sobre o tema levando em conta que os sentidos do que lê podem sempre ser outros, diferentes; logo, para que isso seja possível, o sujeito tem de ter acesso ao arquivo, a uma multiplicidade de sentidos sobre uma dada questão.

Do contrário, ainda de acordo com a autora, a posição discursiva que o sujeito assumirá será apenas a "fôrma-leitor” (PACÍFICO, 2002), que designa uma posição do sujeito na qual, por não ter, então, acesso a esse "arquivo”, ele apenas pode repetir um sentido que foi “cristalizado” e que é, muitas vezes, “legitimado” pelas instituições. 
Para melhor entendermos o que estamos discutindo, vejamos, no recorte 2, um texto argumentativo produzido por um aluno do terceiro ano do Ensino Médio a partir da proposta de redação acima analisada. No caso específico deste recorte, de modo a facilitar a leitura, optamos por também transcrevê-lo, logo abaixo a imagem do texto.

Recorte 2

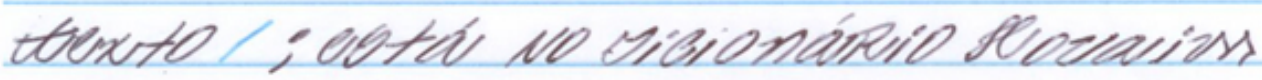

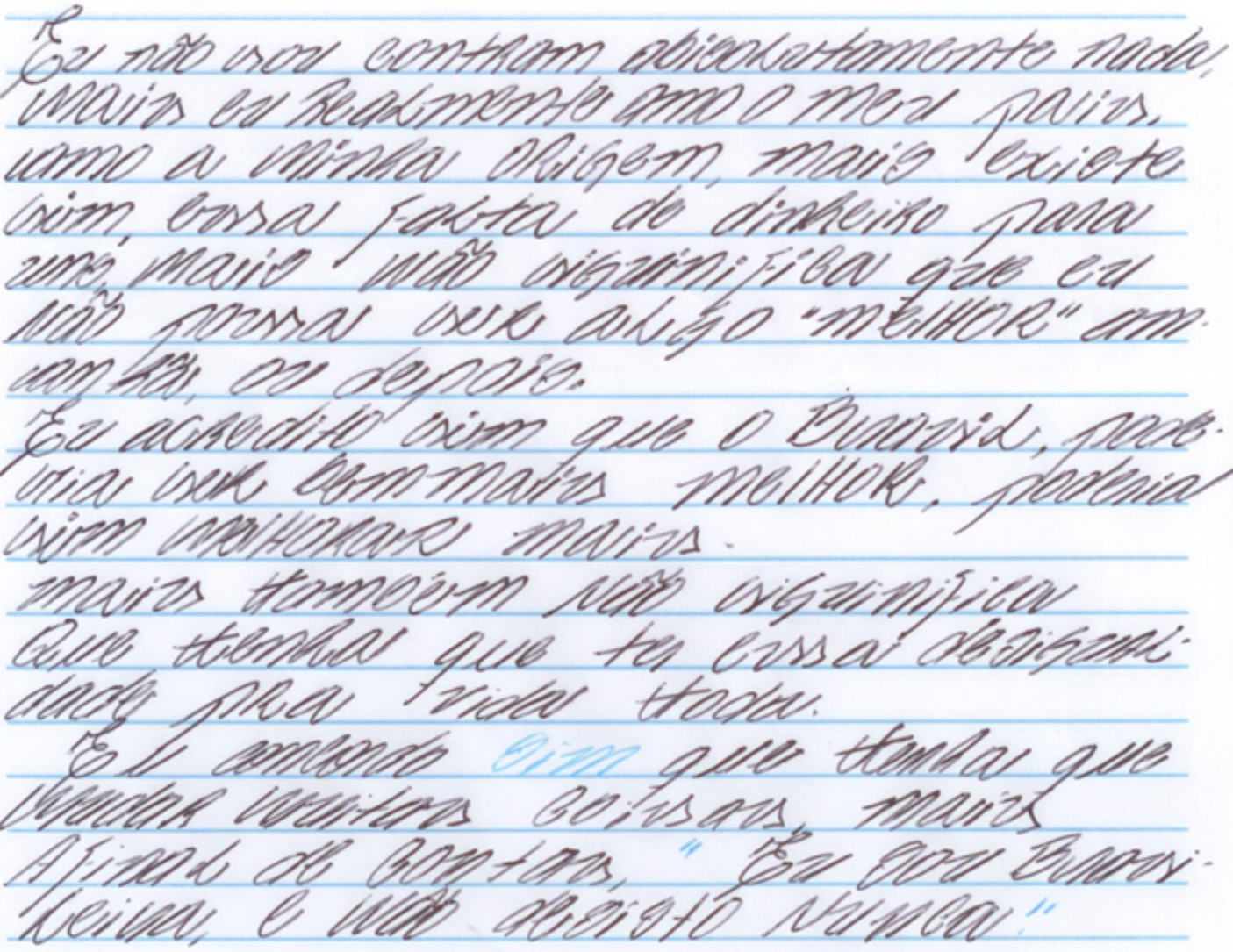


Texto I; esta no dicionário Houaiss

Eu não sou contram abisolutamente nada. Mais eu realmente amo o meu pais, amo a minha origem, mais existe sim, essa falta de dinheiro para uns mais não significa que eu não possa ser algo “melhor” amanhã ou depois.

Eu acredito sim que o Brasil pode vir ser bem mais melhor, poderia sim melhorar mais.

Mais também não significa que tenha que ter essa desigualdade para a vida toda.

Eu concordo sim que tenha que mudar muitas coisas, mais afinal de contas, "Eu sou brasileira e não desisto nunca”

Antes mesmo do início do texto, chama-nos a atenção o fato de que o sujeito-aluno elege como "título" não uma formulação sua que condense a ideia principal de seu texto ou que levante alguma questão pertinente sobre o tema, como poderíamos esperar. Diferentemente, ele retorna ao início da proposta de redação do livro didático e intitula seu texto com os dizeres “texto I: está no dicionário Houaiss”, o que cria um efeito de sentido de que se trata de um resumo do texto apresentado na proposta ou, até mesmo, uma cópia daquilo que o dicionário já trouxe sobre autoestima.

Sabemos que a argumentatividade vem marcada na própria elaboração de um título, pois nele, além de o sujeito-autor chamar a atenção para seu texto, ele já começa a direcionar o leitor para que esse último compartilhe da sua opinião sobre o tema. Soma-se a isso que a ausência de um título “original” no texto do recorte 2 nos leva a questionar se esse aluno assume ou não a autoria de seu texto, pois como já discutido na fundamentação teórica desse trabalho, a função-autor é uma dentre tantas posições que o sujeito pode ou não ocupar e, nesse caso, dar ou não um título ao seu texto representa um forte indício para se pensar a autoria. Isso porque a função-autor envolve o ser "responsável pela organização do sentido e pela unidade do texto, produzindo o efeito de continuidade do sujeito" (ORLANDI, 1996, p.69), movimento esse que estaria, de certa forma, já indicado na criação de um título. Entretanto, não é esse o caminho percebido no texto desse sujeito-aluno que, ao reproduzir em “seu título” um trecho da própria proposta trazida pelo livro didático, legitima ainda mais esse material e demonstra não se permitir duvidar dos sentidos ali presentes. 
Essa posição do sujeito-aluno pode também ser constatada quando, já no início de seu texto, ele diz não ser contra “absolutamente nada”, o que sugere uma completa aceitação daquilo que os textos da coletânea trazem. Podemos atribuir a ausência de posicionamento às condições de produção do texto, pois, se não houver, para esse aluno, a possibilidade do embate de ideias a partir de uma multiplicidade de textos, por exemplo, será mesmo difícil que ele apresente alguma opinião diferente daquela já trazida pelo jornalista. E como sabemos, no caso dessa proposta de produção textual, embora tenha havido, segundo a professora, um espaço para que os alunos colocassem suas opiniões, nenhum outro texto sobre o tema foi trabalhado com os alunos a não ser aqueles presentes na proposta do livro didático.

Possivelmente por isso, ao longo de seu texto, o aluno vai reafirmando o discurso jornalístico, concordando com a visão “otimista”, propagada pela classe dominante, de que o brasileiro deve manter sua autoestima e seu amor pela pátria mesmo diante dos muitos problemas econômicos e sociais do país. Nessa ideia, trazida pelo texto jornalístico da proposta da Fuvest, todas as relações desiguais de poder, toda a crise e miséria em nosso país são abrandadas por um discurso que arquiteta a imagem de um povo feliz e esperançoso. E o sujeitoaluno, impedido do contato com um discurso diverso, com outros sentidos sobre o tema, vê-se impelido a reproduzir esse discurso, e o faz, inclusive, no fechamento de seu texto, através do jargão maior: "sou brasileiro e não desisto nunca”. Concordamos, então, com Pacífico, (2002, p.44-45), pois:

\footnotetext{
E é exatamente desse modo que vemos o trabalho com o texto argumentativo na instituição escolar, pois ao mesmo tempo que são mostradas as características deste texto para o sujeito; que lhe é dito que neste texto ele deve expor seu ponto de vista sobre determinado tema e que, para isso, o sujeito precise de argumentos para fazer valer sua opinião, existe a "influência e o poder" do discurso da classe dominante que é repetido e imposto pelo discurso pedagógico. Sendo assim, o objetivo não é permitir a discussão, a disputa pelo objeto discursivo, mas sim, levar o sujeito a incorporar um ponto de vista que não entre em choque com o defendido pela instituição dominante.
}

Desse modo, ainda de acordo com a autora, não haverá possibilidade de argumentação, uma vez que essa só ocorre "quando não houver consenso, o que não é permitido na escola, lugar onde o consenso é valorizado e ensinado” (PACÍFICO, 2002, p.48). Seguindo nossas análises, contamos agora com outra produção textual no recorte 3 : 
Recorte 3

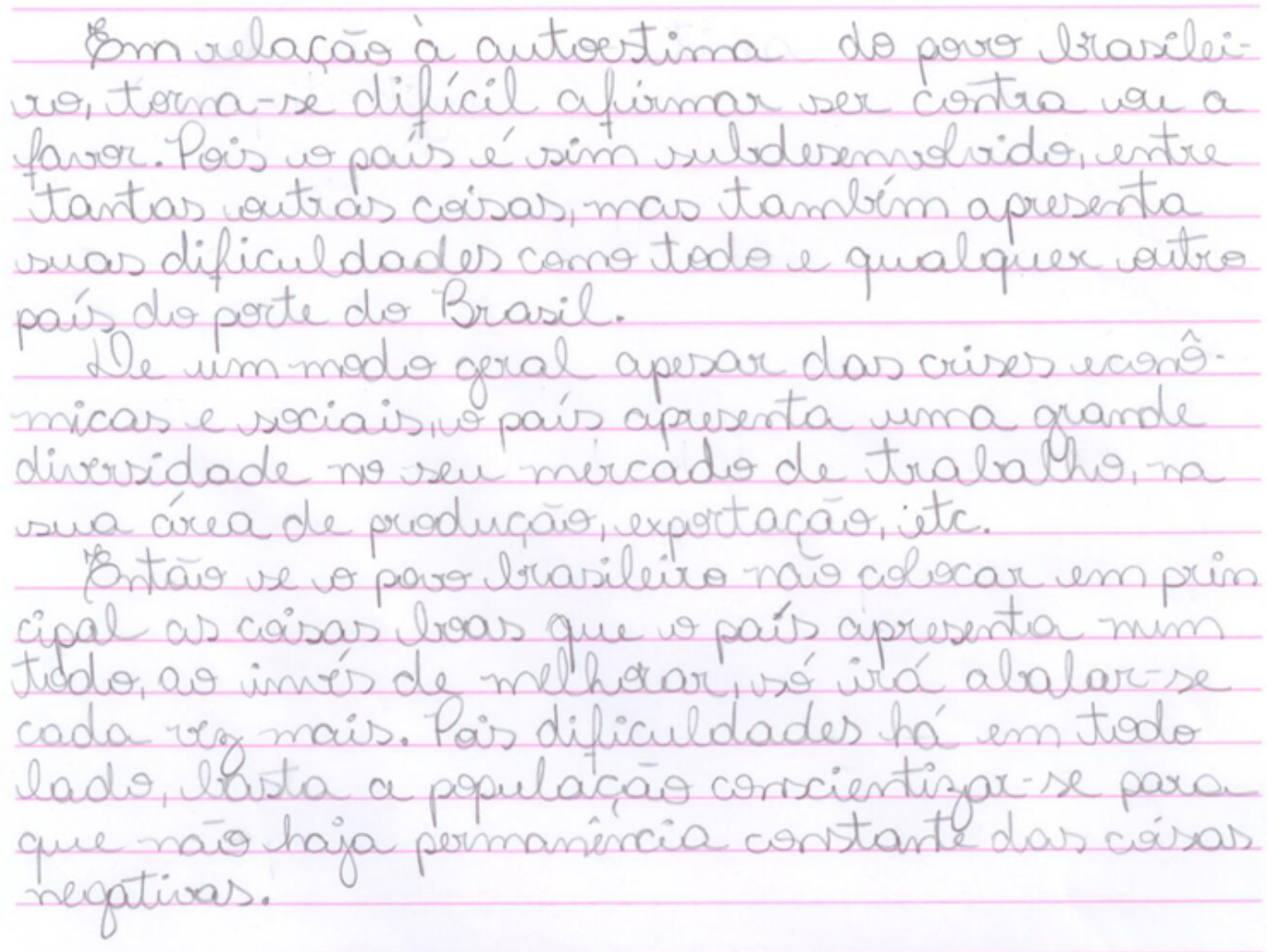

Nesse recorte, temos um texto sem título, no qual o sujeito-aluno marca, desde a primeira frase, o quanto “torna-se difícil afirmar ser contra ou a favor” a questão delineada pela proposta de redação. Compartilhamos dessa angústia manifestada pelo sujeito, pois temos visto, em nossas análises, que a escola não oferece os subsídios necessários para que o aluno confronte ideias e forme sua opinião, o que, nesse caso, colaborou para a dificuldade desse sujeito-aluno em posicionar-se diante da temática.

Notamos nessa produção textual, que, ao tentar assumir um ponto de vista diante do assunto, o sujeito-aluno acaba esbarrando nas opiniões já apresentadas pelo texto jornalístico. Observa-se isso, por exemplo, quando esse sujeito corrobora os dados citados pela revista “Época”, dizendo que “o país é sim subdesenvolvido”, porém, logo a seguir, ele usa a conjunção adversativa “mas”, criando no leitor a expectativa de que algo irá opor-se a essa ideia inicial. Segundo Koch (2001, p.153) “a estratégia do mas é, pois, a de frustrar uma expectativa que se criou no destinatário”, todavia, no texto do aluno, não é isso que acontece, pois ele continua, mesmo após o uso do “mas”, confirmando a noção de subdesenvolvimento ao afirmar 
que o país “também apresenta suas dificuldades como todo e qualquer outro”. Ao mesmo tempo, percebemos nessa última construção, que o aluno busca abrandar as ideias sobre a situação vivida pelo país, ou seja, sem possibilidade do novo, o sujeito do texto analisado repete os sentidos comumente disseminados pela classe dominante de que todos os países têm seus problemas e o Brasil é apenas mais um entre tantos, por isso, talvez, seja saudável e recomendável para o povo brasileiro manter sua autoestima.

Para nós, essa repetição do sentido dominante ocorre porque o livro didático não oferece possibilidades para o aluno polemizar as ideias da mídia - representante maior da classe abastada - ou que, pelo menos, provoque o questionamento, a dúvida. Pelo contrário, ele mesmo assume esse papel de propagador dos sentidos permitidos. Daí o aluno ter a impressão de que tudo que existe sobre a situação do Brasil e sobre a autoestima de seu povo está resumido ali, na coletânea de textos da Fuvest, que circulam no livro didático, como se ter uma elevada autoestima fosse mais importante que resolver a desigualdade social e todos os problemas derivados dela. Desse modo, “aprisionado” por essa ilusão de completude e de que existe apenas um sentido possível, não resta, para esse sujeito, alternativa a não ser reproduzir o que diz o jornalista. Nesse caso, se o professor não supera os limites das páginas do livro e não traz novos textos, novas discussões e possibilidades para o aluno, esse último, certamente, terá sua escrita e autoria comprometidas, como temos visto nessas análises.

Ainda percorrendo o texto do recorte 3, chama-nos a atenção o modo como esse sujeitoaluno, no segundo parágrafo, tenta atenuar o discurso sobre a crise no Brasil, porém, com argumentos que não se sustentam, uma vez que apenas pela "diversidade no seu mercado de trabalho”, o Brasil não seria capaz de sanar toda uma série de problemas que o afetam, principalmente aqueles relacionados à pobreza.

Chegando, “então”, ao último parágrafo de seu texto, o sujeito-aluno retoma uma ideia muito conhecida e difundida pelo senso comum, de que devemos olhar preferencialmente para as “coisas boas que o país apresenta”, de modo a não nos abalarmos com as "dificuldades”. Desse modo, ele reproduz, mais uma vez, sentidos segundo os quais basta pensar positivo e tudo irá resolver-se; silenciando, assim, a responsabilidade das autoridades competentes a respeito da crise mencionada e atribuindo ao povo brasileiro a incumbência de "conscientizarse” para, então, melhorar sua situação.

Outra redação que caminha para essa mesma região de sentidos encontra-se no próximo recorte, denominado recorte 4 : 
Recorte 4

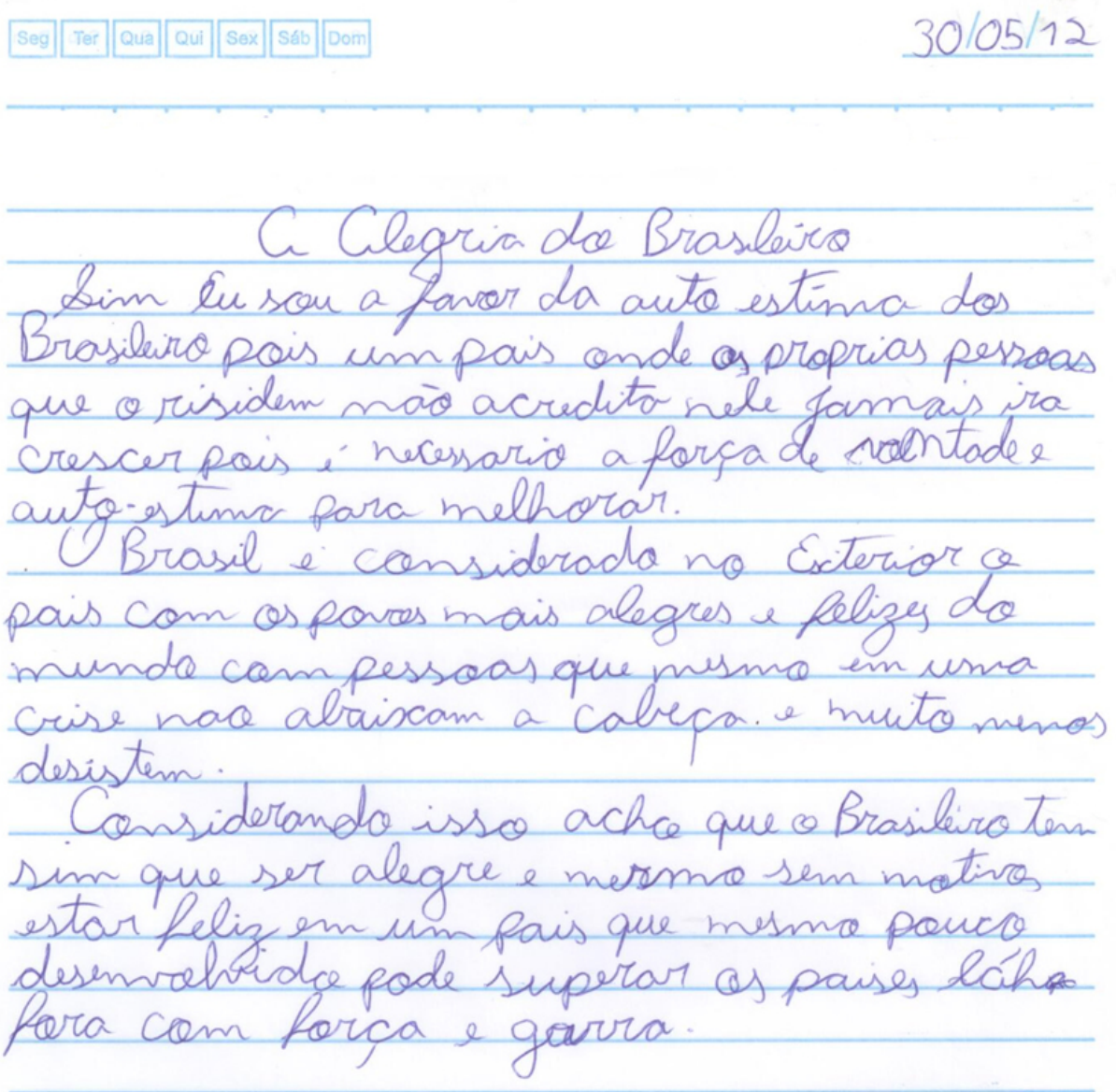

Também nesse recorte, vemos um sujeito capturado pela ideologia dominante e que, assim como o aluno do texto anterior, reforça a conhecida ideia de que o Brasil só irá crescer com “força de vontade e auto-estima”, como se, mais uma vez, fosse total responsabilidade do povo brasileiro superar seus problemas; como se o desenvolvimento do país dependesse apenas da população acreditar no Brasil.

Dessa forma, mesmo afirmando com veemência ser “sim” “a favor da auto estima”, o sujeito-aluno não consegue, apenas com o que lhe foi dado (ou melhor, tirado), munir-se de argumentos realmente persuasivos e, por isso, recorre a concepções corriqueiras e estereotipadas, de acordo com as quais o povo brasileiro é considerado um dos "povos mais alegres e felizes do mundo”. Nesse caso, vemos funcionar a “metáfora de uso” (MOSCA, 2004), ou seja, aquela na qual o sujeito faz circular uma ideia já admitida pela voz coletiva, buscando, então, o consenso. Sobre isso, vale destacar o que dizem os estudos de Pacífico (2002, p.4748): 
Por outro lado, a metáfora de uso sustenta a "argumentatividade” da fôrmaleitor, pois é um sentido que já é previsto e de tanto ser repetido perde sua força argumentativo-persuasiva, pois neste caso é o interlocutor quem cria os mecanismos de antecipação do sentido do discurso que perde seu caráter persuasivo.

Em contrapartida, para que a argumentatividade seja eficaz, o sujeito deve assumir a função-leitor, que permitirá que ele duvide de um sentido único e trabalhe com o novo, com o que Mosca (2004), trazendo à tona os trabalhos de Fontanier, chama de “metáfora de invenção”, ou, em outras palavras, com aquilo que, por seu caráter “inédito”, surpreende o interlocutor.

A partir disso e de nossas análises, observamos que há uma predominância das “metáforas de uso” nos textos desses sujeitos-alunos, fazendo ecoar, muitas vezes, a voz da classe dominante. Isso porque, embora, para a Análise de Discurso, tanto o sujeito quanto o sentido tenha uma natureza incompleta e, por isso, possam sempre se deslocar, sabemos, assim como ORLANDI (2007b, p.54), que:

Entretanto, há também injunções à estabilização, bloqueando o movimento do significante. Nesse caso, o sentido não flui e o sujeito não se desloca. Ao invés de se fazer um lugar para fazer sentido, ele é pego pelos lugares (dizeres) já estabelecidos, num imaginário em que sua memória não reverbera. Estaciona. Só repete.

No entanto, o sujeito, que para a Análise de Discurso também é “sujeito à falha” (ORLANDI, 2007b), pode, em alguns momentos, deslizar em seu dizer e deixar escapar outros e diferentes sentidos. Tomemos como exemplo o recorte 5: 
Recorte 5

$30 / 05 / 12$

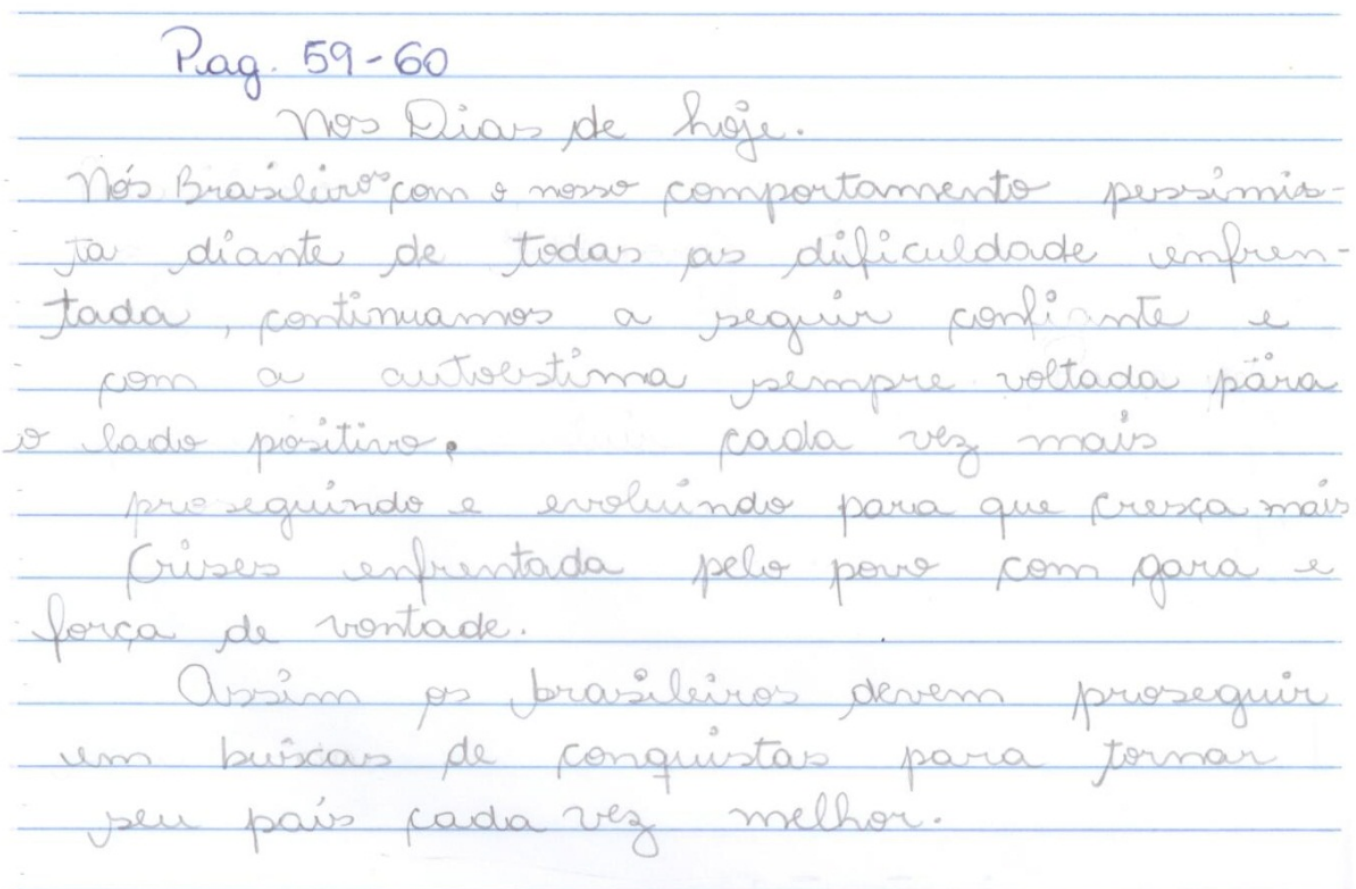

No recorte acima, notamos que o sujeito-aluno, no início de seu texto, se contradiz ao chamar o brasileiro primeiro de "pessimista” e, logo em seguida, de “confiante". Essa contradição pode marcar uma tentativa, por parte do sujeito, de se manter em determinada formação discursiva (de que o brasileiro é pessimista), com a qual talvez se identifique. Contudo, o aluno, que não teve subsídios que permitissem discordar do sentido dominante, volta para a reprodução das ideias apontadas pelo jornalista e migra para a formação discursiva que valoriza o "confiante”.

Notamos ainda que o sujeito-aluno altera o pronome pessoal com o qual inicia seu texto, passando da primeira pessoa do plural, “nós”, onde o sujeito estaria incluído, para a terceira pessoa do plural “eles” (“os brasileiros”). Essa mudança de posição do sujeito pode ser um indício de que ao afirmar o "comportamento pessimista” dos brasileiros, o sujeito inscreve-se em seu escrito, usando o “nós”, pois está falando de sua opinião, segundo a qual os brasileiros não são tão felizes quanto quer nos apregoar a classe dominante através da mídia. Todavia, voltando a corroborar os sentidos de autoestima e de "força de vontade" trazidos pelo discurso 
jornalístico, ele muda o pronome e, com isso, cria um efeito de afastamento do objeto discursivo, como se dali para frente esse sujeito fosse falar de uma opinião com a qual não concorda - a do jornalista -, porém se vê obrigado a reproduzi-la, uma vez que é a "garantida” e aceita pela escola.

Outro exemplo desse movimento de retorno ao sentido garantido pode ser observado no recorte 6, abaixo:

\section{Recorte 6}

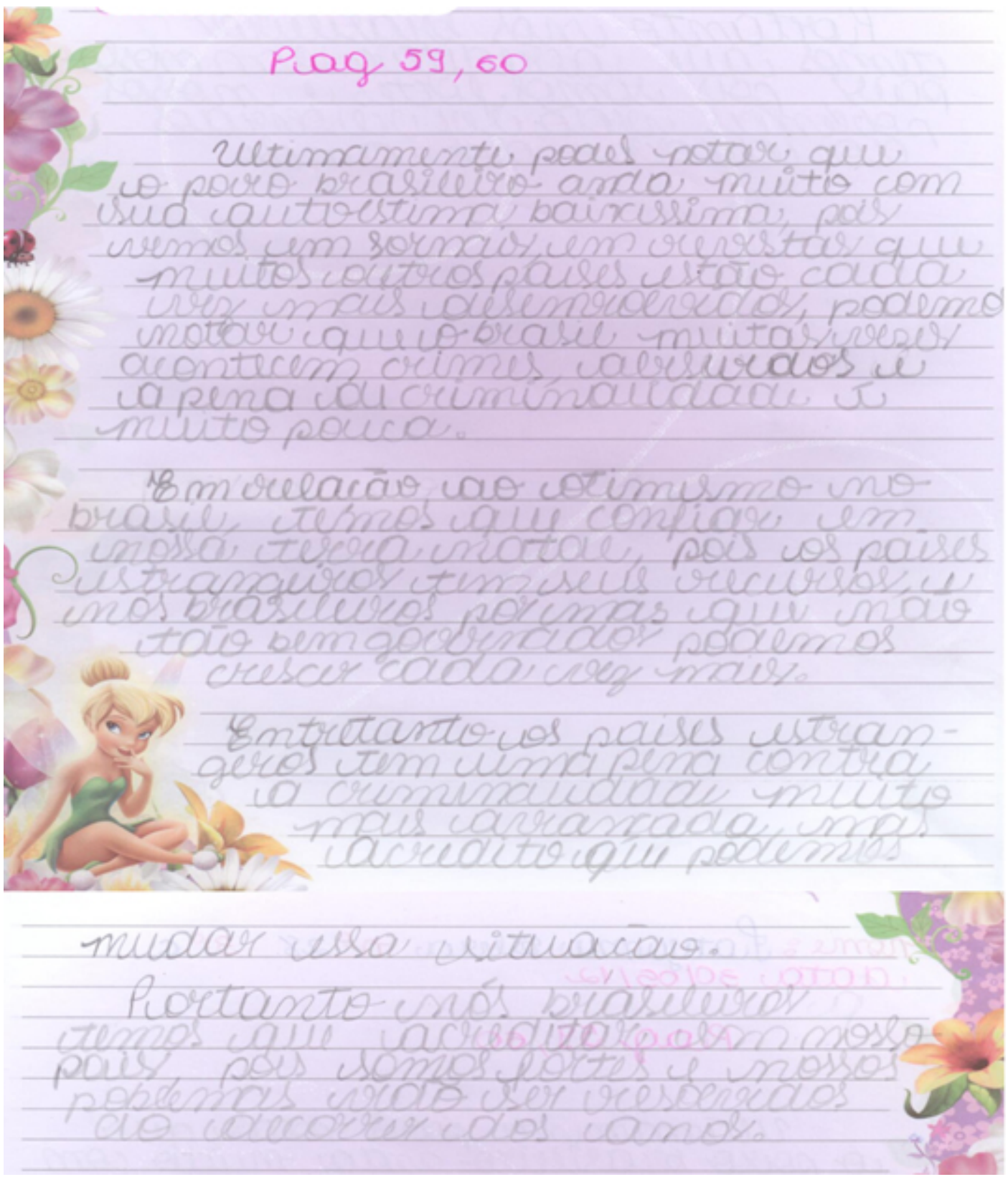


“Pag 59, 60”. É assim que o sujeito-aluno desse texto, como o do anterior, marca que terá início sua dissertação argumentativa, fazendo referência às páginas do livro didático. Observamos, no entanto, que o recorte anterior apresenta título. No recorte 6, não é apenas a ausência de título que reclama nossa atenção, mas, sobretudo, o fato de o aluno ter feito referência às páginas do livro didático para, então, começar seu texto, como se fosse preciso citar o material didático para validar a sua produção textual, ou como se seu escrito não tivesse sentido desvinculado das páginas nas quais a proposta de redação se insere. Esse movimento do aluno leva-nos a questionar: há um interlocutor, de fato, para os escritos dos alunos, na escola? Para quem o aluno escreve? Por que e para quem ele argumenta?

Isso acontece porque, como sabemos, o livro didático funciona na escola como um discurso de verdade, ou seja, como "aquele que ilusoriamente se estabelece como um lugar de completude dos sentidos” (GRIGOLETTO, 1999, p.67-68) daí a necessidade do aluno de buscar respaldo nesse material.

Sendo o livro didático, então, considerado como essa voz de verdade dentro do espaço discursivo da escola, “no qual os sentidos já estão estabelecidos” (GRIGOLETTO, 1999, p.68), o sujeito-aluno fica condicionado a reproduzir o que traz esse manual. Por isso, assim como no recorte 5 , também aqui, nesse recorte 6 , deparamo-nos com um movimento no qual o sujeito começa falando a partir de uma posição - contrária à exposta no livro didático -, mas, logo em seguida, migra para outra região de sentidos e reitera o discurso do jornalista. Vemos isso quando o aluno inicia seu texto apontando a "baixíssima” autoestima do povo brasileiro devido ao baixo índice de desenvolvimento do Brasil em comparação com outros países; porém, já no segundo parágrafo, defende que nós brasileiros devemos “confiar em nossa terra natal”, o que nos remete, novamente, às ideias pré-concebidas e apontadas pelo discurso jornalístico de que o brasileiro é um povo esperançoso e que acredita em melhorias para seu país.

Essas mudanças de posição do sujeito e os efeitos de sentido provocados por elas nos revelam o quão difícil fica para o sujeito argumentar quando outras possibilidades de sentidos lhe são interditadas. Em razão disso, percebemos também que os sujeitos-alunos dos textos analisados, muitas vezes, mostram-se confusos e com opiniões que parecem ainda estarem indefinidas a respeito dos objetos discursivos, o que, por sua vez, impossibilita que o texto seja persuasivo.

Outra consequência desse constante deslocamento do sujeito encontra-se no próprio comprometimento da coerência, ou seja, no arranjo das partes do texto e na relação que essas partes estabelecem entre si. 
Sabemos que para que um texto seja coerente - e no caso específico da argumentação isso é altamente relevante -, as ideias apresentadas devem estabelecer entre si uma relação harmônica, fazendo com que o texto caminhe numa direção lógica e que vá dirigindo o leitor para a aceitação das opiniões ali expostas. Entretanto, percebemos que os sujeitos-alunos mostram dificuldade para manter a coerência do início ao fim de seus textos, fazendo parecer, por vezes, que as ideias, em seus textos, estão avulsas, desconexas. Um exemplo disso pode ser observado ainda nesse recorte 6, quando o aluno chega, inclusive, a pular uma linha da folha para começar um novo parágrafo de seu texto, marcando fortemente sua mudança de formação discursiva e alterando o efeito de sentido que se pretendia criar (PACÍFICO, 2002).

Temos visto, até agora, textos que caminham para uma mesma direção quanto aos sentidos, beirando quase que uma padronização quando reproduzem (assujeitam-se) as ideias da classe dominante. Isso, para nós, é efeito do modo como trabalha a instituição escolar que, muitas vezes, inclusive por meio do livro didático, nega aos alunos a possibilidade de contestação, a disputa pelo objeto discursivo e, assim, condena esses sujeitos-alunos à repetição de um sentido já “moldado”, trazido por alguma voz de autoridade. Mas e quando, mesmo diante dessa situação, o aluno resiste e desloca-se para outra região de sentidos? Vejamos um caso exemplar disso no recorte 7: 


\section{Recorte 7}

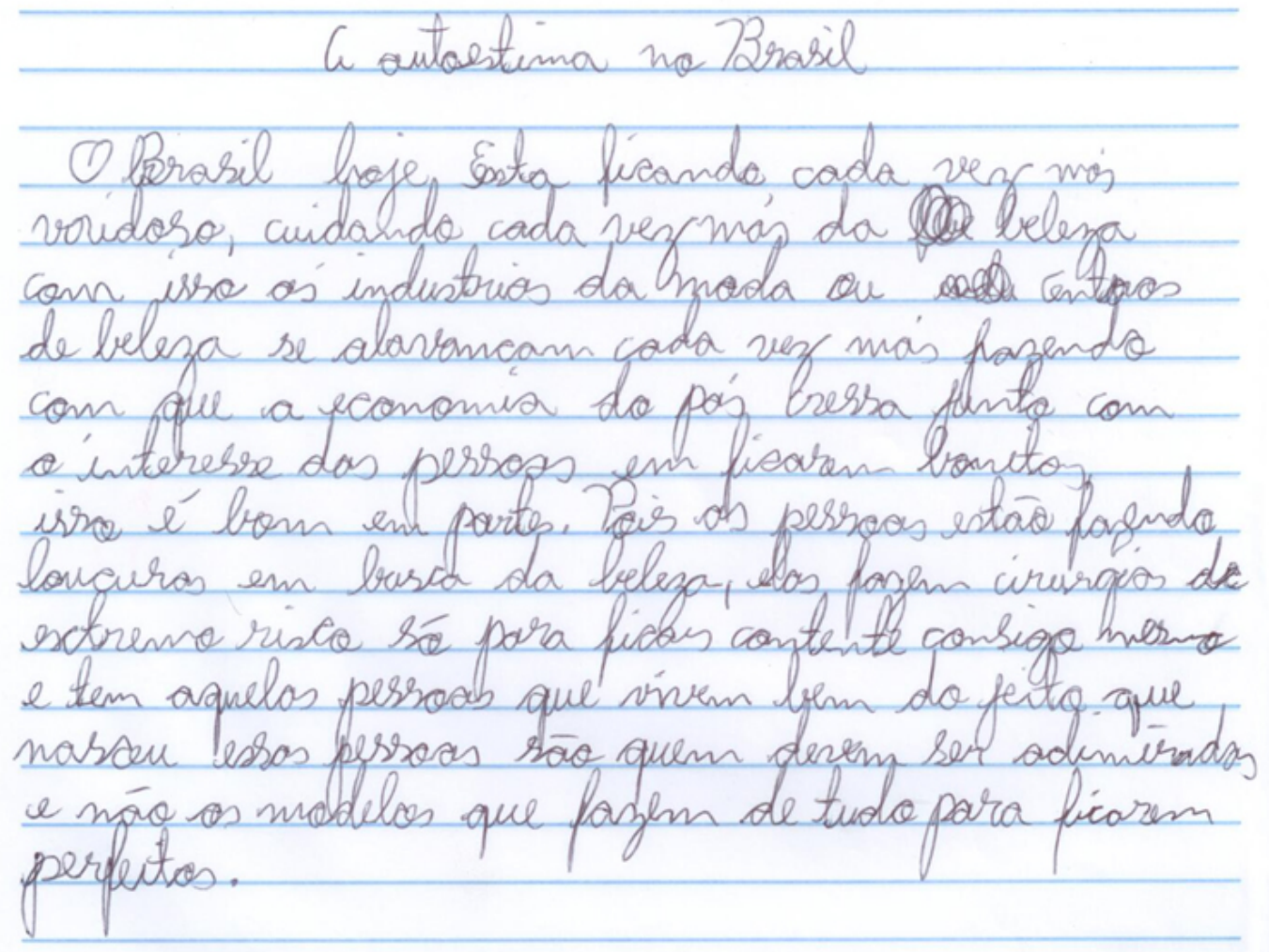

Dentre as várias produções textuais que analisamos, essa última, do recorte 7, destacase por escapar dos sentidos que já tinham sido apresentados nos textos da coletânea da Fuvest e que foram reproduzidos pela maioria dos sujeitos-alunos. Aqui, o sujeito rompe com tudo que vinha sendo dito e permite-se falar sobre outro sentido de autoestima, dessa vez relacionando a palavra aos sentidos de beleza, vaidade e preocupação com a aparência física.

Essa ruptura, que poderia ser considerada meramente como um erro por representar, talvez, uma fuga do tema proposto, para nós analistas, funciona como um indício da resistência desse aluno que, recusando-se a repetir os sentidos já trazidos, estranha e rejeita a proposta silenciadora do livro didático.

Mesmo assim, o sujeito-aluno não consegue desenvolver uma argumentação persuasiva, pois não recebe da escola subsídios como, por exemplo, outros textos ou até mesmo outras possibilidades de leitura e interpretação para os textos do livro didático. Nesse sentido, podemos refletir também sobre o papel do professor, pois se ao invés de a escola trabalhar com uma proposta já antiga da Fuvest, o aluno pudesse ter acesso a uma coletânea de textos organizada pelo próprio professor, contando, inclusive, com textos produzidos por esse docente, o resultado certamente seria diferente desse que estamos observando em nossas análises. No entanto, presos 
aos sentidos impostos pelo livro didático, os sujeitos-alunos não se sentem autorizados a ultrapassar os limites de leitura e interpretação estipulados dentro dessa ferramenta e, por consequência, não chegam a argumentar com persuasão.

Essa interdição à argumentação pode ser também verificada se atentarmos para a extensão dos textos produzidos pelos sujeitos-alunos, pois, uma vez que temos nos recortes apresentados os textos na íntegra, observamos certa recusa à escrita por parte desses alunos, o que, para nós, pode estar relacionado tanto ao silenciamento da teoria sobre argumentação, como vimos no capítulo anterior, quanto ao modo fechado com que o livro didático trabalha em suas propostas de redação, praticamente impondo a repetição de um sentido único. Daí o desinteresse do aluno em realizar uma tarefa que exige apenas a repetição, sem a possibilidade desse aluno se colocar, debater e defender seu ponto de vista.

Não obstante, vimos no capítulo anterior que ao sujeito-aluno não é permitido duvidar do discurso trazido pelo livro didático, pois ele não é levado a questionar as interpretações, posições e sentidos trazidos pelo texto jornalístico, principalmente quando esse último é trazido como uma espécie de molde para que, através dele, os sujeitos-estudantes possam produzir seus “próprios” textos argumentativos. A voz do jornalista é, assim, elevada e sua opinião é ratificada pelo aluno, que, sem acesso a uma multiplicidade de textos e sem possibilidade de confronto, vê-se obrigado a reproduzir e parafrasear tal opinião.

Em contrapartida, defendemos que quando é permitido a esse sujeito-aluno duvidar, questionar ou até mesmo confrontar os sentidos trazidos pelo texto jornalístico com outros sentidos, presentes em outras materialidades textuais; quando uma teoria sobre argumentação é apresentada a esse aluno, ele, enquanto sujeito falante, sujeito de/à linguagem, diante uma dada temática, é capaz de interpretar e de atribuir “novos” sentidos, refletindo e posicionandose perante os objetos ou fatos apresentados. Torna-se possível, dessa maneira, para esse aluno, nas palavras de Campos (2011, p.233), “construir conhecimento em torno de discursos vivos em que ecoam vozes dentro de um espaço de circulação que permite ao leitor/aluno/professor a réplica e a polêmica.”.

Importante dizer que não temos a visão ingênua de que apenas apresentar as teorias sobre argumentação fará o aluno mudar de posição discursiva, isto é, de sujeito-argumentado para sujeito que argumenta. Funcionando junto com a teoria, a escola tem de construir espaços para o aluno exercitar o poder de argumentar. Nesses espaços, que não são geográficos, mas sim, discursivos, os alunos têm de vivenciar a argumentação, a disputa do dizer em situações de fato, com interlocutores de fato, para que eles, em contato com o arquivo (PÊCHEUX, 2010) possam compreender o objeto discursivo, conhecê-lo, saber do que se trata, dos sentidos 
construídos sócio-historicamente sobre dada questão, construir a imagem do interlocutor (para quem eu escrevo, ou com quem eu falo), saber despertar as paixões no interlocutor e sentir-se autorizado a assumir seus pontos de vista, mesmo que sejam opostos aos do discurso dominante.

Para isso, é preciso mudar a relação dos sujeitos com os sentidos, com as vozes de autoridade legitimadas no contexto escolar, a fim de que a argumentação seja usada pelo sujeito, em suas práticas sociais, sejam elas escolares ou não. 


\section{CONSIDERAÇÕES FINAIS}

Esta página, por exemplo, não nasceu para ser lida. Nasceu para ser pálida, um mero plágio da Ilíada, alguma coisa que cala, folha que volta pro galho, muito depois de caída.

Nasceu para ser praia, quem sabe Andrômeda, Antártida

Himalaia, sílaba sentida, nasceu para ser última

a que não nasceu ainda.

Palavras trazidas de longe pelas águas do Nilo, um dia, esta pagina, papiro,

vai ter que ser traduzida, para o símbolo, para o sânscrito, para todos os dialetos da Índia, vai ter que dizer bom-dia ao que só se diz ao pé do ouvido, vai ter que ser a brusca pedra onde alguém deixou cair o vidro.

Não é assim que é a vida?

(Paulo Leminski - Aviso aos náufragos)

Pensar o trabalho voltado para o desenvolvimento da argumentação na escola implica necessariamente levar em conta o modo como a leitura vem sendo trabalhada em sala de aula, pois para que o aluno escreva de maneira argumentativa, é preciso que, antes, ele seja exposto a uma diversidade de textos acordes e discordes sobre os temas e que possa realizar uma leitura crítica desses textos, de modo a construir seu ponto de vista. Consideramos, aqui, então, a necessidade de um trabalho plural com a(s) leitura(s), sobre o qual Orlandi (2008, p.87) acrescenta:

Quando me refiro à pluralidade das leituras não estou pensando apenas na leitura de vários textos, mas, sobretudo, na possibilidade de se ler um mesmo texto de várias maneiras. Este é um aspecto fundamental no aspecto de significação que a leitura estabelece. 
Para que esse tipo de trabalho com a leitura aconteça, é fundamental pensar discursivamente sobre os textos que são colocados para os alunos, ou seja, há que se considerar o texto enquanto discurso, resgatando sua historicidade e levando em conta as várias formações discursivas que o atravessam. Só assim seria possível, para os estudantes, realizarem leituras polissêmicas, entendendo, a partir dos mecanismos de produção dos sentidos de um determinado texto, que os sentidos não nascem, mas são produzidos e, por isso, podem sempre ser outros. Esse tipo de leitura coloca o sujeito na posição de quem não apenas lê, decodificando informações, mas, acima de tudo, expõe-se à opacidade da língua e compreende o texto; e como bem coloca Orlandi (2008, p.117), “sem teoria não há compreensão”.

Por essa razão, para que o sujeito-aluno seja capaz de escrever, defendendo seu ponto de vista, além desse trabalho que possibilite leituras plurais sobre as diversas temáticas, ele precisa ter acesso ao saber, o que, a nosso ver, depende não apenas do domínio da escrita, mas também do contato desse aluno com conhecimentos teóricos sobre a argumentação.

A fim de esclarecermos quais seriam, então, os conhecimentos teóricos sobre a argumentação que poderiam circular na escola, partimos de um dos primeiros estudos de que temos notícia sobre essa teoria, a saber, os estudos retóricos do filósofo Aristóteles. A partir disso, foi possível observar que são muitos os conceitos e saberes envolvidos na argumentação e, portanto, torna-se preocupante a redução desse conteúdo a um simples olhar para o texto jornalístico. Cabe lembrar que entendemos a argumentação como um conhecimento de direito dos sujeitos-alunos e acreditamos ainda que a construção da cidadania passa pelo aprendizado desse conteúdo.

Nesse sentido, considerando que o livro didático é, ainda hoje, um dos mais importantes portadores de texto usado dentro da sala de aula, voltamos nosso olhar cuidadosamente para essa ferramenta e buscamos analisar se/como a argumentação está sendo apresentada aos alunos, por meio dos livros didáticos que constituíram nosso corpus. A partir, então, das análises realizadas, percebemos que os livros didáticos “silenciam” (ORLANDI, 2007a) as teorias sobre a argumentação que existem e que poderiam/deveriam ser apresentadas aos sujeitos-alunos. Verificamos, ainda, que, ao mesmo tempo em que se escamoteia a argumentação, o discurso midiático, na forma de textos jornalísticos, ganha enorme destaque dentro desse material, aparecendo seguidas vezes como texto modelo nos quais os alunos devem basear-se para construir seus textos argumentativos. Além disso, vimos vigorar, no modo como o livro trata o texto jornalístico, um ensino tradicional que privilegia a estrutura formal do texto e concordamos com Rojo (2008, p.89-90) quando ela aponta que: 
Nas práticas de leitura e produção, assim como nos materiais didáticos que circulam em sala de aula, o texto entra menos como produtor de sentidos e mais como suporte de análises gramaticais, agora também textuais, como se o mero conhecimento de estruturas e tipos textuais, regras e normas pudesse fazer circular o diálogo e os sentidos.

E não apenas isso, notamos que as questões propostas pelo livro a respeito dos textos midiáticos configuram-se como questões fechadas, ou seja, questões que não incitam uma leitura crítica do texto e que, por isso, não permitem a circulação de outros sentidos a não ser aqueles já trazidos pelo jornalista. Tais questões propõem apenas um retorno do aluno ao texto jornalístico para que ele vá coletando informações, como se isso, por si só, bastasse para que o sujeito pudesse construir sua opinião sobre o objeto discursivo e argumentar em favor dela. Dessa forma, o material didático conduz os alunos a uma leitura parafrástica dos textos midiáticos, primando pela reprodução não apenas da forma desses textos, mas também dos sentidos que eles carregam. Dizemos, então, que a escola silencia a argumentação e impossibilita a assunção da autoria quando oferece o discurso jornalístico aos seus alunos não para incitar o debate ou o questionamento do mesmo, mas apenas para legitimar os sentidos trazidos por esse discurso.

Tendo aceitado o desafio de trabalhar com a Análise de Discurso, foi possível pensarmos discursivamente nosso objeto de investigação. Assim, conseguimos identificar e analisar os efeitos não apenas de um evento específico, mas do processo que envolve a construção dos sentidos no discurso jornalístico e o modo como ele circula na escola, por meio do livro didático.

Vale destacar ainda que o trabalho com o livro didático se configurou como um riquíssimo aprendizado, na medida em que, as investigações acerca do papel que o mesmo exerce na sala de aula, de sua autoridade na escola e da suposta legitimidade dos sentidos que traz proporcionaram uma nova forma de olhar para esse material.

Tendo em vista essa nova concepção sobre o funcionamento discursivo do livro didático, foi possível, então, analisar de maneira menos ingênua a presença do discurso jornalístico nesse material, o que, por sua vez, após nossas análises, permite-nos dizer que a forma como isso vem ocorrendo na escola não parece colaborar para a formação de sujeitos leitores e autores, mas, ao contrário, amplia uma realidade de desigual distribuição do saber, afastando os mesmos da escrita, especialmente, da argumentação. Desse modo, a esses estudantes do Ensino Médio não está sendo permitido ocupar a posição de quem questiona, debate e argumenta sobre os temas propostos, mas, ao contrário, notamos o que parece ser 
apenas uma injunção para seguir um esquema textual determinado e repetir os sentidos privilegiados pelo livro didático.

Diante dessa situação, analisamos ainda as implicações desse modo de funcionamento do livro didático nas produções textuais dos alunos. Observamos, assim, que, os sujeitos-alunos não conseguem, de fato, levantar e sustentar, com argumentos consistentes, pontos de vista sobre as temáticas apresentadas. Ao invés disso, pudemos notar, nos textos desses alunos, um constante retorno aos sentidos produzidos pelo discurso jornalístico, como se neste estivessem os sentidos corretos sobre o objeto em discussão. Atribuímos isso ao fato de os mesmos estarem impedidos do contato com os conhecimentos teóricos sobre a argumentação e de serem levados a uma leitura “engessada” do discurso midiático.

Consideramos necessário, então, olhar atenciosamente para a situação que ora apresenta-se, pois entendemos que a escola deve ser o lugar de circulação das teorias sobre argumentação e, além disso, é na escola que o aluno deve entrar em contato com o discurso polêmico (ORLANDI, 2003), com leituras que lhe forneçam repertório para a construção de sua opinião e com a possibilidade de colocar-se diante de determinado assunto e não apenas de repetir sentidos já produzidos por outrem sobre as diversas temáticas.

No entanto, não buscamos, por meio desse estudo, atestar que a circulação do discurso jornalístico na escola seja a razão do afastamento entre os sujeitos e a argumentação. Sabemos que a questão vai muito mais longe, pois a princípio é uma questão de poder. Além disso, pode ser relacionada, inclusive, com práticas de letramento pautadas no modelo autônomo, ou seja, num modelo no qual a escrita seria "um produto completo em si mesmo, que não estaria preso ao contexto de sua produção para ser interpretado” (Kleiman, 1995, p.22).

Mesmo assim, não podemos nos abster de olhar com cautela para a atual circulação de textos midiáticos dentro da escola, até porque, como aponta Orlandi: "não é só quem escreve que significa; quem lê também produz sentidos” (ORLANDI, 1993b, p.101) e, portanto, ao terem acesso apenas aos sentidos produzidos pelos jornalistas, os sujeitos-alunos não têm acesso ao arquivo (PÊCHEUX, 2010) e, como consequência, não conseguem exercer sua autoria nem argumentar sobre o objeto discursivo.

Podemos dizer, então, que a escola, embora seja tida como o lugar designado para a circulação dos conhecimentos teóricos - incluindo o da argumentação - e do discurso polêmico, não tem promovido a propagação desse saber e nem mesmo vem cumprindo seu papel de instaurar discussões e reflexões sobre as diversas temáticas. Ao contrário, nossas análises nos permitem afirmar que a escola tem trabalhado com o discurso autoritário (ORLANDI, 2003), no qual o sujeito-aluno tem limitada (ou praticamente anulada) a possibilidade de discordar e 
de argumentar a respeito do objeto de estudo. Entretanto, entendemos que a argumentação só é possível quando ao aluno é permitida a contraposição de ideias e o debate.

Nesse contexto, vemos a importância do papel do professor na mediação entre os alunos e o livro didático, pois se o educador se ativer apenas a esse instrumento e não colocar em dúvida os discursos trazidos por ele, mais verdadeiros os sentidos inscritos nele parecerão e maior será a distância entre sujeitos e a escrita argumentativa.

Entendemos, portanto, que o modo como o professor trabalha com o discurso jornalístico pode determinar, em grande parte, a validação da voz do jornalista e sua posterior reprodução por parte do aluno. Isso porque, assim como Romão e Pacífico (2007a, p.12):

[...] consideramos a existência de um discurso sobre o discurso jornalístico, o qual sustenta o sentido de que o jornal traz assuntos atuais, coloca o leitor em contato com os principais assuntos do dia, informa a população com imparcialidade, e que aquele que não lê fica desatualizado. Diante disso, podemos dizer que o acesso a estes sentidos pode fazer o leitor assumir a fôrma-leitor (que não duvida da transparência da linguagem e repete um dizer; cf. Pacífico, 2002).

Nesse sentido, não se pode desconsiderar o fato de que o livro didático, material que vem trazendo o discurso jornalístico para a escola, apresenta-se como detentor da "verdade absoluta”, ou seja, “aquele que traz o sentido pronto, correto, legitimado e, portanto, deve ser respeitado e repetido” (PACÍFICO; ROMÃO, 2007b, p. 27). E não apenas isso, deparamo-nos, também, com uma realidade na qual, muitas vezes, o professor, ocupando o "lugar que ele julga ser o lugar ocupado pelo detentor do saber legitimado” (PACÍFICO, 2002, p.55), promove a circulação do discurso autoritário, no qual só há a possibilidade da paráfrase, ou seja, da repetição de um sentido pronto e cristalizado, que nesse caso, trata-se do sentido trazido pela mídia através do jornalista.

Confirmando tal realidade e destacando a situação do professor dentro desse quadro, Grigoletto (1999, p.68) diz que “o professor recebe um "pacote” pronto e espera-se dele que o utilize. Ele é visto como um usuário, assim como o aluno, e não como analista”. Dessa maneira, o discurso midiático no livro didático, como parte deste "pacote” a ser disseminado, pressupõe um leitor que não estaria apto a lidar com uma teoria mais elaborada sobre a argumentação e, talvez, por isso, a suposta necessidade de utilizar o discurso jornalístico como arquétipo a partir do qual o aluno aprenderá o que é argumentar. Por outro lado, sabemos que para construir sua autoria, o sujeito-aluno precisa acessar o “arquivo” (PÊCHEUX, 2010); o que não acontece quando o mesmo é interditado por um texto pronto que, ilusoriamente, "traz tudo" acerca de determinado assunto. 
Por esse motivo, e considerando o professor também como um escritor, entendemos que deve fazer parte de seu trabalho produzir textos e utilizá-los em sala de aula. Desse modo, esse próprio “autorizar-se” do professor já seria responsável por abrir espaço para que os alunos também se autorizem, tanto no sentido de produzirem leituras polissêmicas e formarem suas opiniões quanto no de tornarem-se, de fato, autores de seus textos.

Percebemos ainda a necessidade de um “autorizar-se” no caso do trabalho com as teorias da argumentação, pois sua interdição na escola pode estar relacionada com a circulação de um discurso que afirma ser esse um conhecimento muito complexo e que, portanto, não deve circular, de maneira direta, na escola. Outras vezes, ainda, veicula-se outro discurso, o de que a argumentação é trabalhada de modo implícito, ou seja, sua teoria encontra-se subentendida nas práticas didáticas do ensino da produção do texto dissertativo-argumentativo. No caso do primeiro discurso, impede-se o contato do aluno com a teoria da argumentação por uma suposição que, na verdade, subestima esses estudantes e, no segundo caso, silencia-se essa teoria ao mesmo tempo em que se simula sua presença por meio, por exemplo, do texto jornalístico. Daí nos perguntarmos: seria, então, só a Universidade, o lugar de encontro dos sujeitos com os conhecimentos teóricos e o lugar no qual se exige que ele argumente?

Ora, pelo que foi discutido nesse trabalho de mestrado, sabemos que a resposta negativa é a que melhor cabe para a pergunta acima, pois duvidamos dos sentidos propagados pelos discursos que menosprezam a relação que os alunos podem ter com a "arte de argumentar" e consideramos de extremo valor os estudos da argumentação não apenas para a produção de textos, mas, principalmente, para "a formação geral do jovem como protagonista da coisa pública, como leitor e produtor crítico, replicante, de discursos globalizantes, como multicultural em sua cultura e poliglota em sua língua” (ROJO, 2008, p.100). 


\section{REFERÊNCIAS}

ARISTÓTELES. Retórica. Tradução de Edson Bini. São Paulo: EDIPRO, 2011.

AUTHIER-REVUZ, J. Entre a transparência e a opacidade: um estudo enunciativo do sentido. Porto Alegre: EDUPUCRS, 2004.

BAKHTIN, M. Le príncipe dialogique. Paris: Seuil, 1981.

BATISTA, A. A. G. Um objeto variável e instável: textos, impressos e livros didáticos. IN: ABREU, M. (org.). Leitura, história e história da leitura. Campinas: ALB/Mercado de Letras; São Paulo: FAPESP, 1999.

BRASIL. Ministério da Educação. Secretaria de Educação Básica. Guia de livros didáticos: PNLD 2012 - Língua Portuguesa. Brasília: Ministério da Educação, Secretaria da Educação Básica, 2011.

CAMPOS, M. I. B. Textos argumentativos em materiais didáticos: que proposta seguir? DELTA. v. 27, n. 2, 2011.

CORACINI, M. J. As representações do saber científico na constituição da identidade do sujeito-professor e do discurso de sala de aula. IN: CORACINI, M. J. (org.). Identidade e discurso: (des)construindo subjetividades. Campinas: Editora da UNICAMP, 2003.

FERNANDES, C. A. Análise do discurso: reflexões introdutórias. Goiânia: Trilhas Urbanas, 2005.

FERREIRA, M. C. L. A ciranda dos sentidos. IN: ROMÃO, L. M. S.; GASPAR, N. R. (org.). Discurso midiático: sentidos de memória e arquivo. São Carlos: Pedro \& João Editores, 2008.

GARCIA, R. (org.). Novos olhares sobre a alfabetização. 3. ed. São Paulo: Cortez, 2008.

GINZBURG, C. Sinais: Raízes de um Paradigma Indiciário. IN: GINZBURG, C. Mitos, emblemas, sinas: morfologia e história. Tradução de Federico Carotti. 2. ed. São Paulo: Companhia das Letras, 2002.

GNERRE, M. Linguagem, escrita e poder. 4. ed. São Paulo: Martins Fontes, 1998.

GRIGOLETO, M. Leitura e funcionamento discursivo do livro didático. IN: CORACINI, M. J. (org.). Interpretação, autoria e legitimação do livro didático. Campinas: Pontes, 1999.

HOUAISS, A.; VILLAR, M. S. Dicionário da Língua Portuguesa. Rio de Janeiro: Objetiva, 2001.

KLEIMAN, A. (org.). Os significados do letramento: uma nova perspectiva sobre a prática social da escrita. Campinas: Mercado das Letras, 1995.

KOCH, I. G. V. Argumentação e linguagem. 13. ed. São Paulo: Cortez, 2011. 
MAINGUENEAU, D. Novas tendências em análise do discurso. Tradução de Eni Pulcinelli Orlandi. 3. ed. Campinas: Pontes; Editora da Universidade Estadual de Campinas, 1997.

MOSCA, L. L. S. (org.). Retóricas de ontem e de hoje. São Paulo: Humanitas Editora, 1999.

ORLANDI, E. P. Discurso fundador: a formação do país e a construção da identidade nacional. São Paulo: Pontes, 1993a.

. O inteligível, o interpretável e o compreensível. IN: ORLANDI, E. P. Discurso e leitura. 2. ed. São Paulo: Cortez; Editora da UNICAMP, 1993b. 1996. Interpretação: autoria, leitura e efeitos do trabalho simbólico. Petrópolis: Vozes, Discurso e Texto: formação e circulação dos sentidos. Campinas: Pontes, 2001. 2003. A linguagem e seu funcionamento: as formas do discurso. 4. ed. Campinas: Pontes, As formas do silêncio: no movimento dos sentidos. 6 ed. Campinas: Editora da Universidade Estadual de Campinas, 2007a.

Análise de discurso: princípios e procedimentos. 7. ed. Campinas: Pontes, 2007b. Cortez, 2008.

As histórias das leituras. IN: ORLANDI, E. P. Discurso e Leitura. 8. ed. São Paulo:

OSAKABE, H. Argumentação e discurso político. São Paulo: Kairós, 1979.

PACHECO, M. M. O ideário ilustrado e os primórdios da oficialização do ensino da Retórica no Brasil. Anais do II Seminário Nacional Literatura e Cultura. v. 2. São Cristóvão: GELIC, 2010.

PACÍFICO, S. M. R. Argumentação e autoria: o silenciamento do dizer. 2002. 190 f. Tese (Doutorado em Psicologia Educacional) - Faculdade de Filosofia, Ciências e Letras de Ribeirão Preto, Universidade de São Paulo, Ribeirão Preto.

PACÍFICO, S. M. R. Leitor e efeitos da leitura dos textos midiáticos e didáticos. IN: ROMÃO, L. M. S.; GASPAR, N. R. (org.). Discurso midiático: sentidos de memória e arquivo. São Carlos: Pedro \& João Editores, 2008.

PACÍFICO, S. M. R.; ROMÃO, L. M. S. Da cartilha ao e-mail e à peça publicitária: os portadores de texto marcando a inclusão/exclusão do sujeito na escrita. Revista Linguagem em Discurso. v. 7, n. 2, p. 313-325, 2007a.

PACÍFICO, S. M. R.; ROMÃO, L. M. S. (org.). Leitura e escrita: no caminho das linguagens. Ribeirão Preto: Alphabeto Editora, 2007b.

PÊCHEUX, M. Semântica e Discurso: uma crítica à afirmação do óbvio. Tradução de Eni Puccinelli Orlandi [et. al.] 2. ed. Campinas: Editora da UNICAMP, 1995. 
PÊCHEUX, M. O discurso: estrutura ou acontecimento. Tradução de Eni Puccinelli Orlandi. 2. ed. Campinas: Pontes, 1997.

PÊCHEUX, M. Papel da Memória. IN: ACHARD, P. [et. al.]. Papel da Memória. Tradução de José Horta Nunes. 2. ed. Campinas: Pontes, 2007.

PÊCHEUX, M. Ler o arquivo hoje. IN: ORLANDI, E. P. (org.). Gestos de leitura: da história do discurso. Tradução de Bethania S. C. Mariani. 3. ed. Campinas: Editora da UNICAMP, 2010.

PERELMAN, C.; OLBRECHTS-TYTECA, L. Tratado da Argumentação: a nova retórica. São Paulo: Martins Fontes, 1999.

PFEIFFER, C. C. O lugar do conhecimento na escola: alunos e professores em busca da autorização. Série Escritos: escrita, escritura, cidade (III). v. 7, n. 1, p. 9-20, 2004.

RAZZINI, M. P. G. O espelho da nação: a antologia nacional e o ensino de português e de literatura (1838-1971). 2000. 247 f. Tese (Doutorado em Letras) - Instituto de Estudos da Linguagem, Universidade Estadual de Campinas, Campinas.

ROJO, R. Gêneros de discurso/texto como objeto de ensino de língua: um retorno ao trivium? IN: SIGNORINI, I. (org.). [Re]discutir texto, gênero e discurso. São Paulo: Parábola editorial, 2008

ROMÃO, L. M. S.; PACÍFICO, S. M. R. Era uma vez uma outra história: leitura e interpretação na sala de aula. São Paulo: DCL, 2006.

ROMÃO, L. M. S.; PACÍFICO, S. M. R. Mora-dores de rua falados e significados no/pelo discurso jornalístico. Revista Rua. UNICAMP, v. 13, p. 9-20, 2007.

SOARES, M. Português na escola: história de uma disciplina curricular. IN: BAGNO, M. (org.). Linguística da norma. São Paulo: Loyola, 2002.

TFOUNI, L. V. Letramento e alfabetização. 2. ed. São Paulo: Cortez, 1995 (Nova Coleção Questões da Nossa Época, v. 15). 


\section{LIVROS DIDÁTICOS ANALISADOS}

BARRETO, R. G. (org.). Ser Protagonista: Português. v. 3. São Paulo: Edições SM, 2010.

CEREJA, W. R.; MAGALHÃES, T. C. Português: linguagens. São Paulo: Atual, 2003.

SARMENTO, L. L.; TUFANO, D. Português: literatura, gramática, produção de texto. v. 3. São Paulo: Moderna, 2010.

TORRALVO, I. F.; MINCHILLO. C. A. C. Linguagem em movimento. v. 3. São Paulo: FTD, 2010. 